\title{
الشائعات عبر مواقع التواصل الاجتماعى وعلاقتها بمستوى القلق السياسى للدي الشباب المصرى
}

د. نادية محمد عبد الحافظ (*)

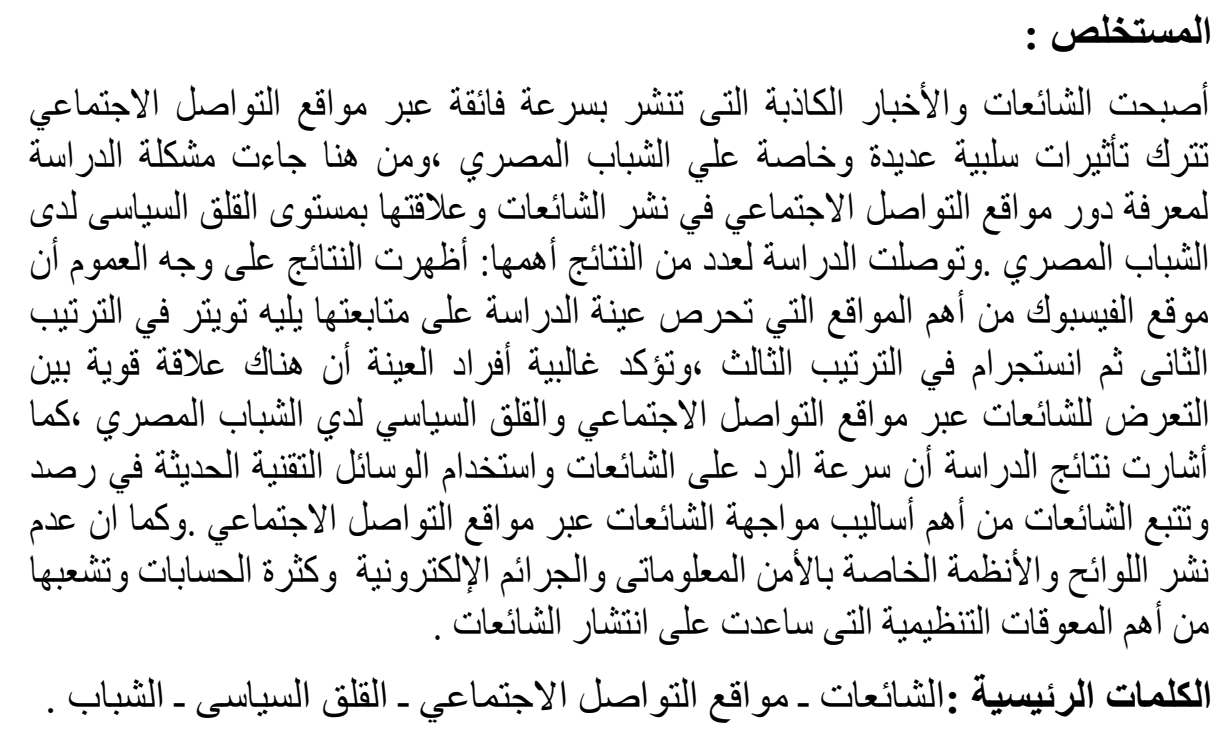

\section{Rumors on social media and their relationship to the level of political anxiety among Egypatian Youth}

This study aimed to monitor , analyze and interpet the relationship between the rumer on social media and the level of political anxiety among egypation youth.the study was based on the survey as atool for collecting study data ,the most important results of study are most of the respondents follow facebook. The majority of respondents affirm that there is astrong relationship between exposure to rumor and political anxity among youth .One of the most important regulatory obstacles that helped spreed rumors is the lack of information security regulations .

The main words: Rumors - Social media -political anxiety -Youth

* * استاذ مساع بقسم الاعلام التزبوى بكلية التربية النوعية ـ جامعة الزقازيق. 
تعد مواقع التواصل الاجتماعى أحد أهم أثنكال الإعلام الجديد ، حيث أحدثت طفرة

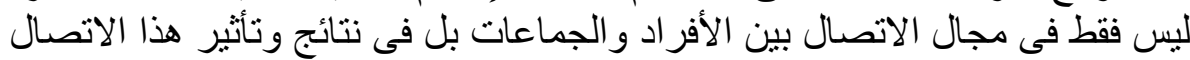

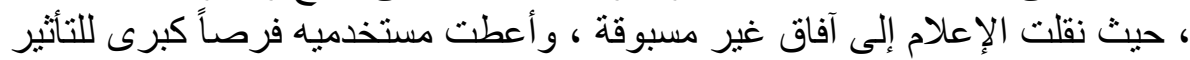

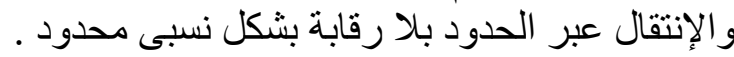

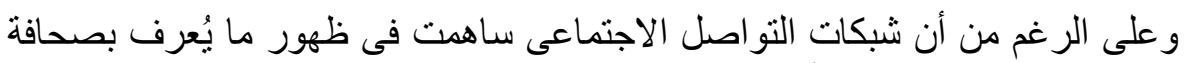

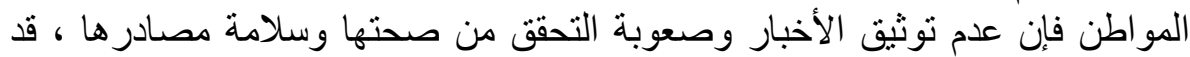

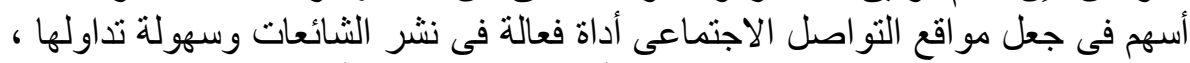

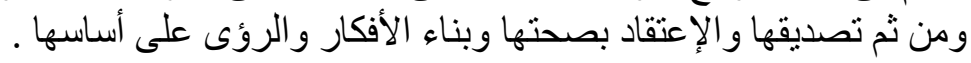

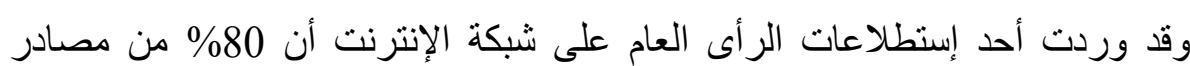

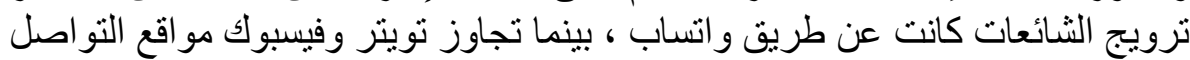

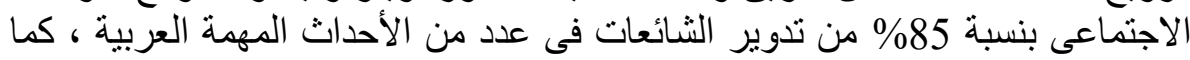

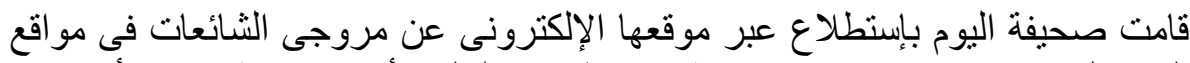

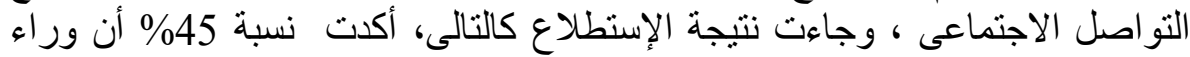

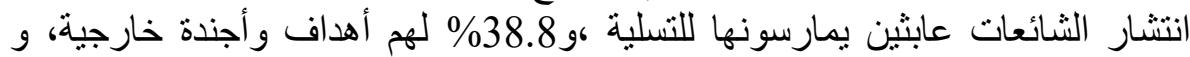
15.8\% مرضى نفسيون (ممدوح السيد عبد الهادى ، 2018).

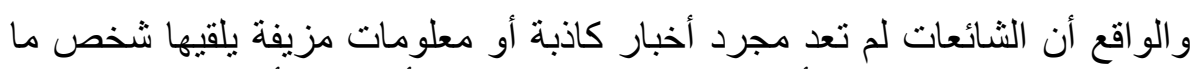

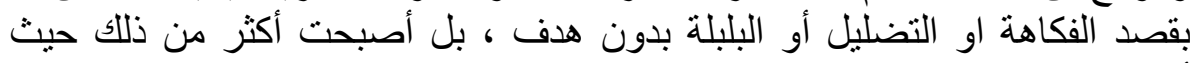

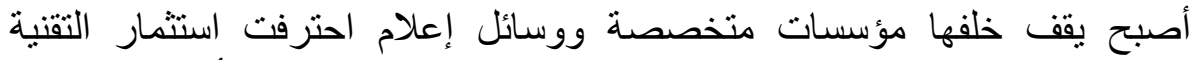

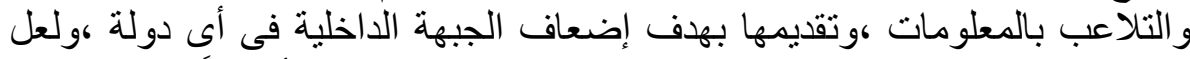

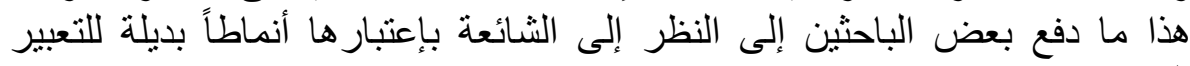

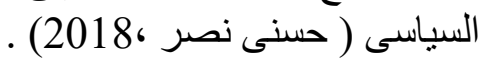

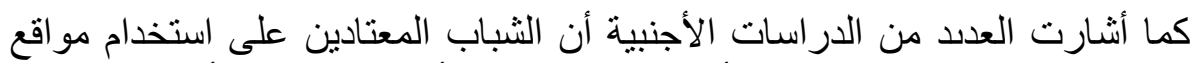

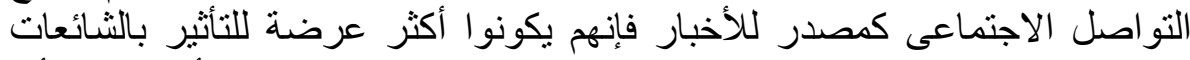

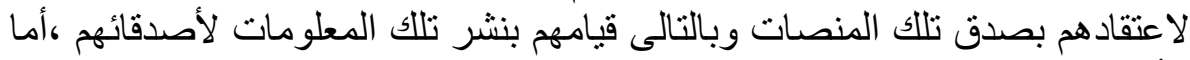

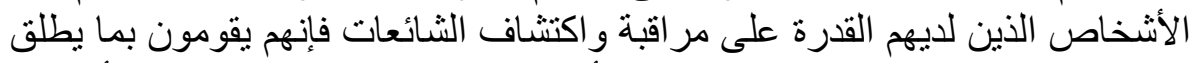

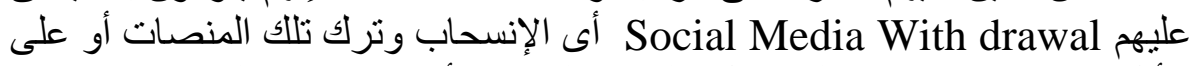

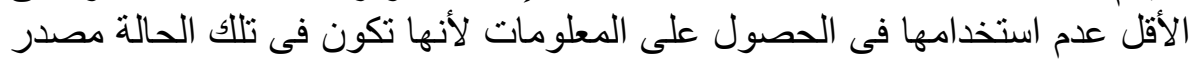

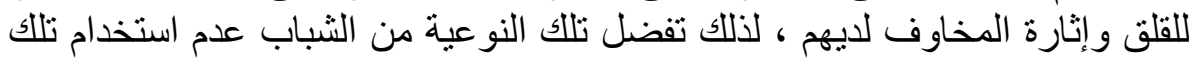

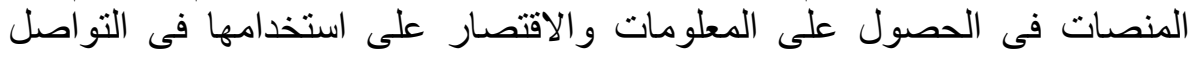
و الحياة الاجتماعية (Killy. A Rodamer,2018 ) . 


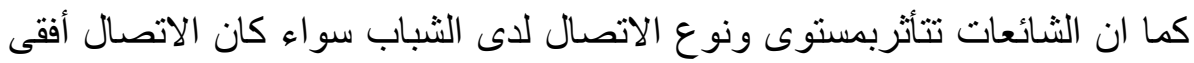

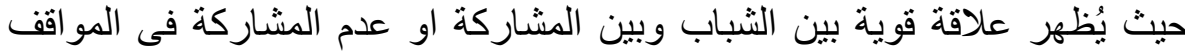

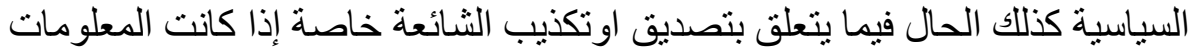

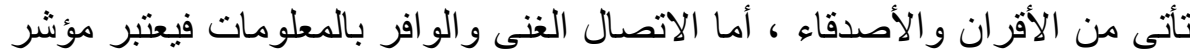

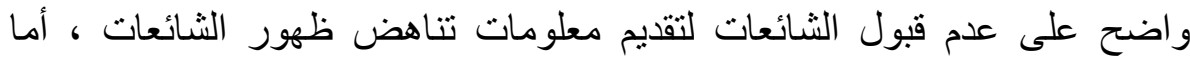

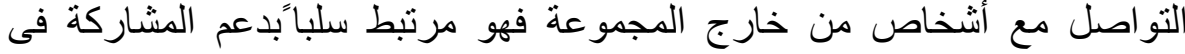

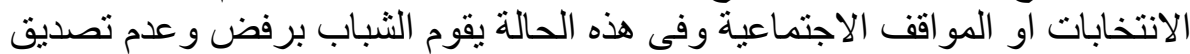

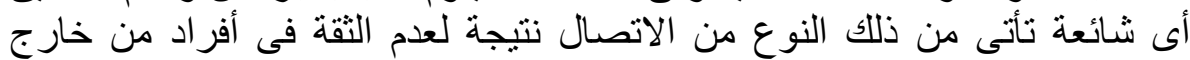

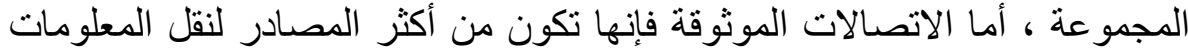

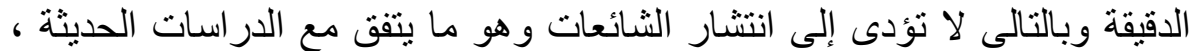

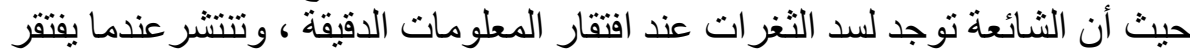

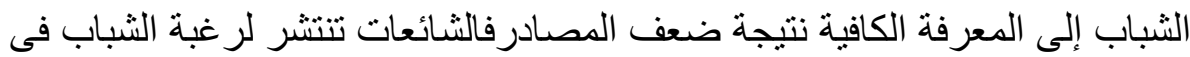

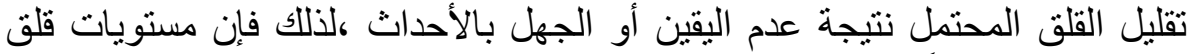

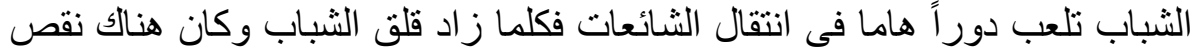

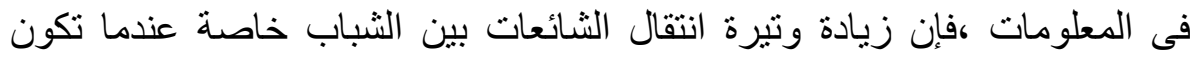

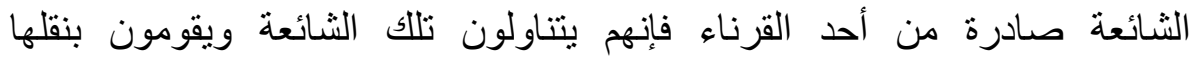

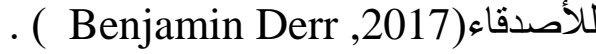

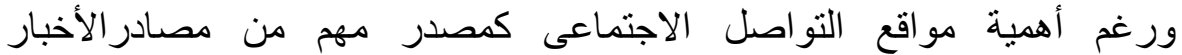

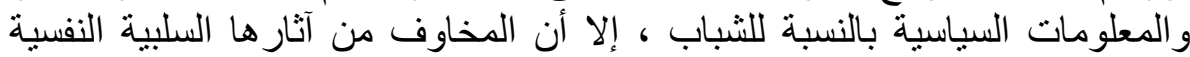

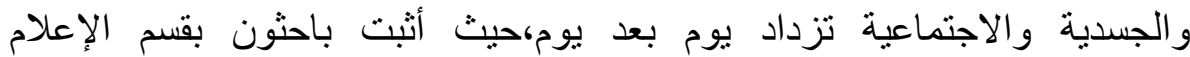

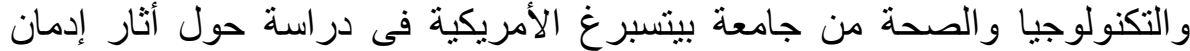

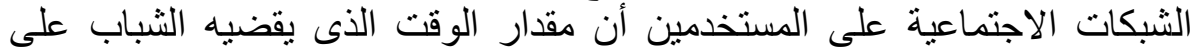

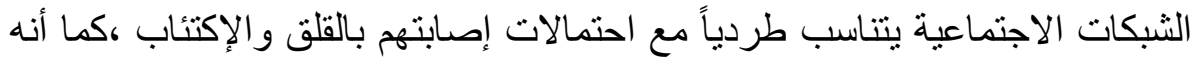

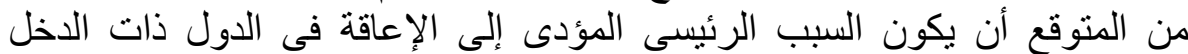

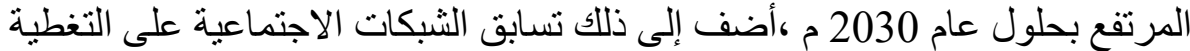

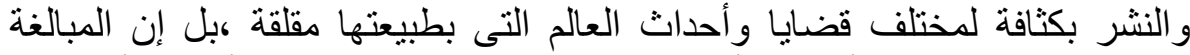

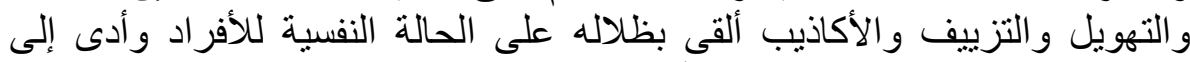
انتشار القلق و التردد حول مختلف الأحداث و القضايا (سعاد الحديدى،2016) .

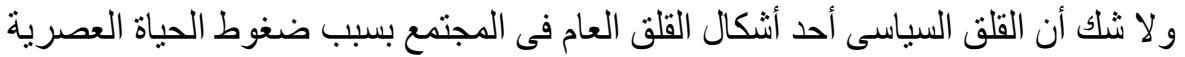

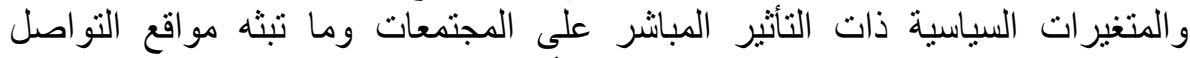

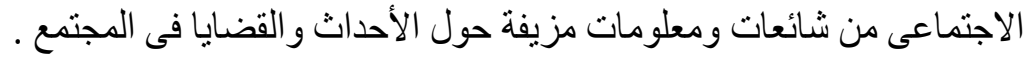

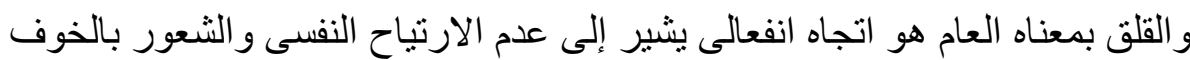

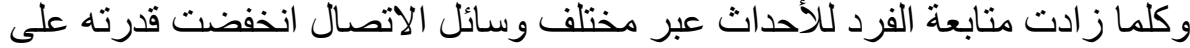
التركيز وبالتالى ارتفع إحساسه بالقلق ( هبة محمد ، 2010) ـ 


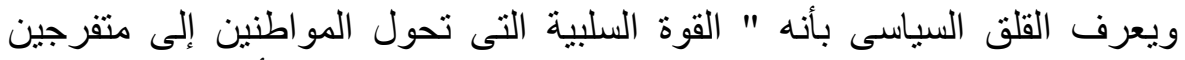

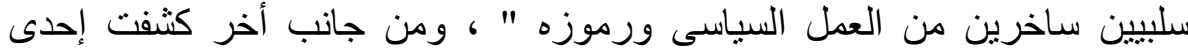

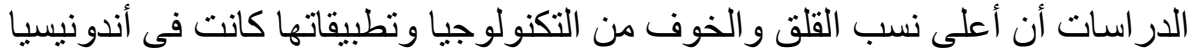

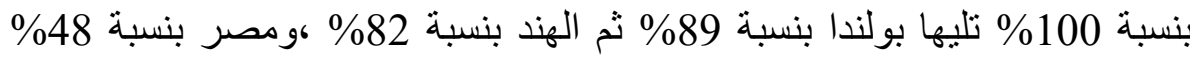

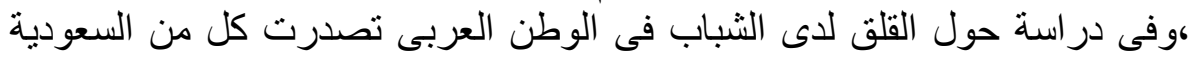
والإمارات ولبنان والكويت وعمان أقل معدلات القلق فى الدول العربية (بدرى الأنصارى، الأمارات ولنان

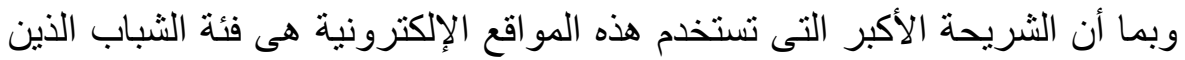

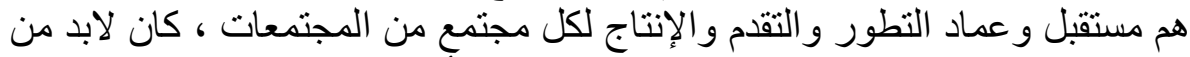

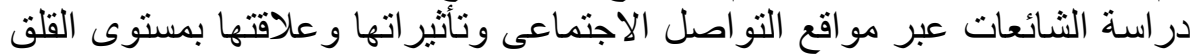

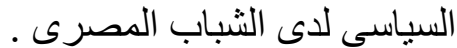

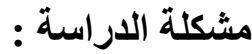

أصبحت الشائعات من أهم المظاهر الاجتماعية التى بدأت تطفو على السطح بشكل

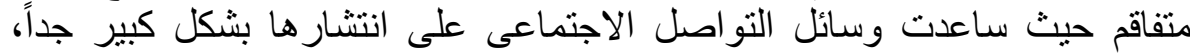

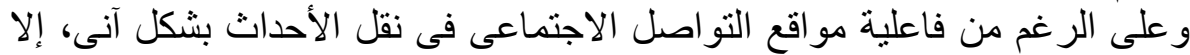

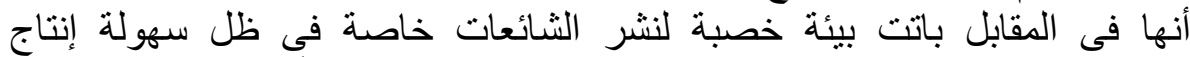

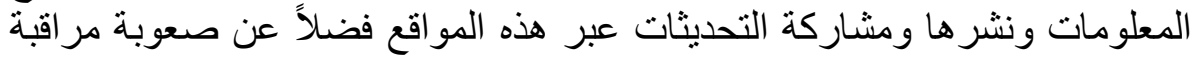
المحتوى الذى ينشره المو اطنون ، على عكس ما يحدث في وسائل الإعلام التقليدية. ولذلك يتضح أن مو اقع التو اصل الإجتماعى قد لا تكون أدوات ووسائل منو افقة كلية

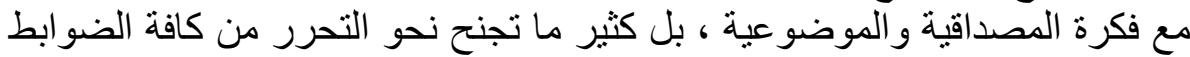

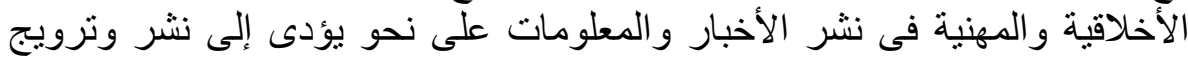

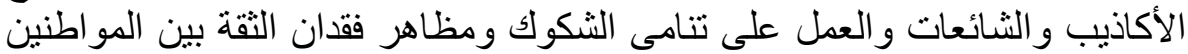

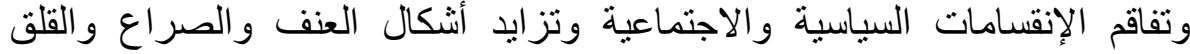

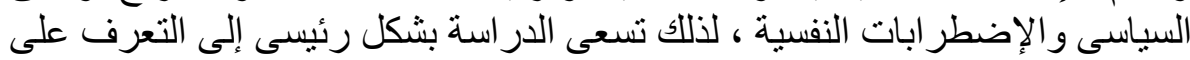

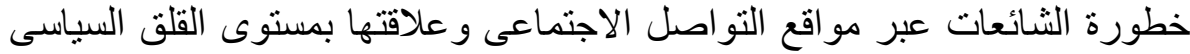

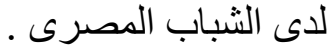

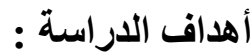

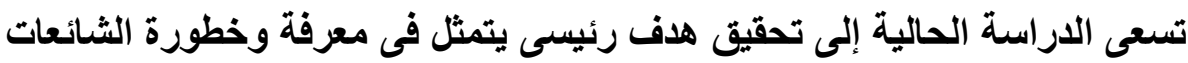

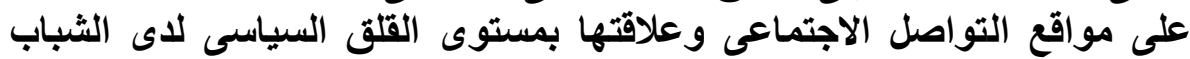
المصرى ، ويمكن تحقيق هذا الهـف من خلال :-

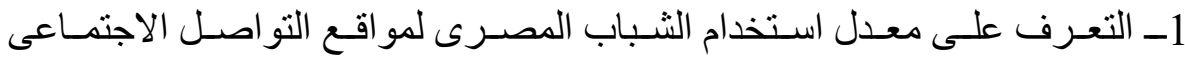

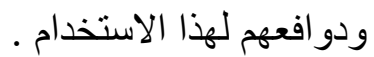
2ـ تحديد أهم الأنشطة التى يقوم بها الثنباب المصرى من خلال استخدامه لمو اقع التو اصل الاجنماعى. 
3- رصد أبرز الصفحات الإخبارية التى يستخدها الثباب الدصرى على مواقع التواصل .

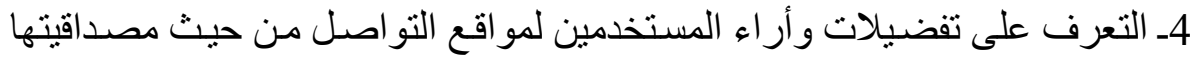

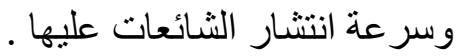

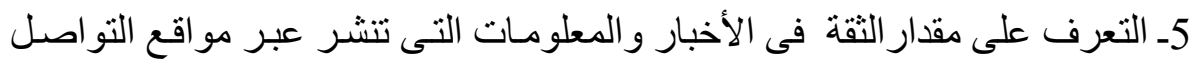

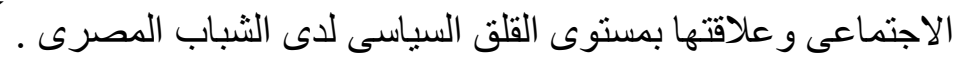

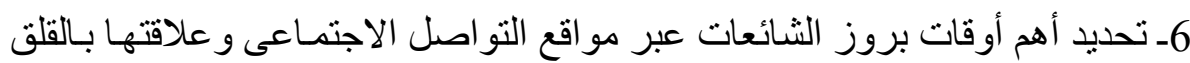

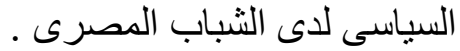

7ـ التعرف على المعوقات التنظيمية و الثخضصية التى سـاعدت على انتشـار الثنائعات

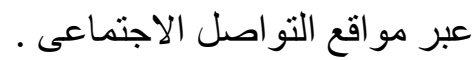

8ـ التعرف على دور الثنائعات عبر مو اقع التُ التواصل اصل الاجتمـاعى ودور هـا فى إحداث القلق السياسى لدى الثنباب .

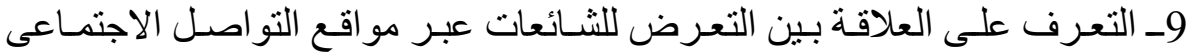
ومستوى القلق السياسى لدى الثباب لئرض

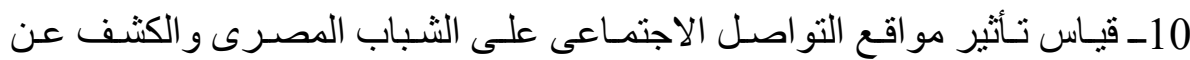

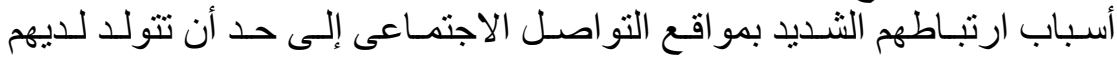

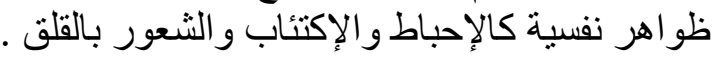

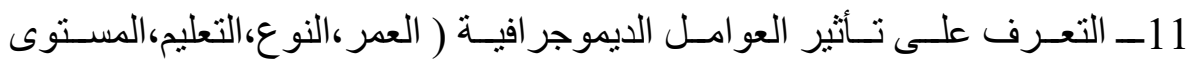

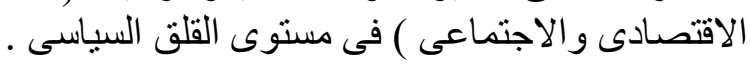

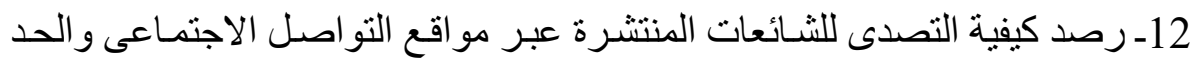
من دور ها فى إحداث القلق السياسى لألى الثنباب .

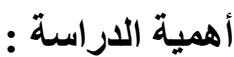

إن لكل دراسة علمية أهميتها التى تحث الباحث على إجرائها وتنبع أهميتها من عدة نقاط أساسية وهى كالتالى :-

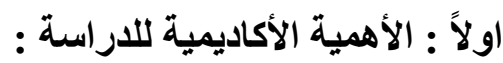

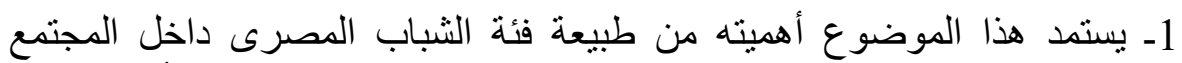

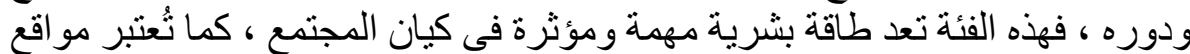

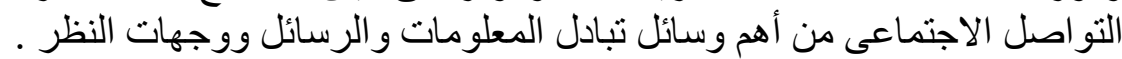

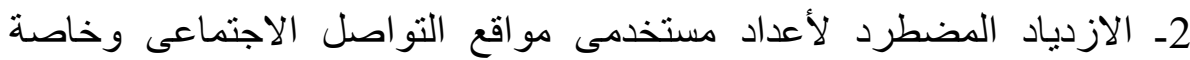

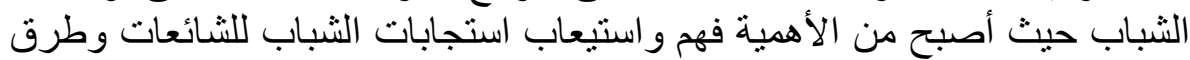
تفاعلهم باعتبارهم مصدر قوة المجتمعات ،حيث اتسع الفارق بين التقريرين 
السنويين ( الخامس الصادر فى يونيو 2014) والساد الصنادر في في ديسمبر

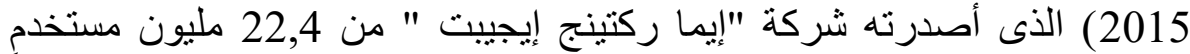

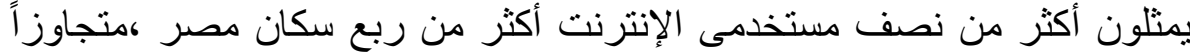

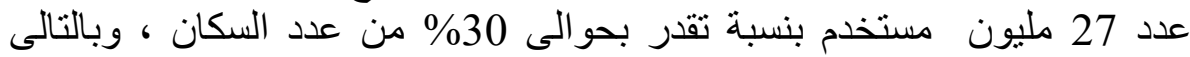

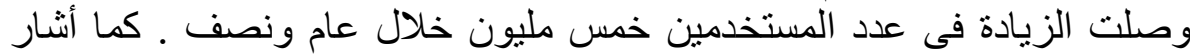

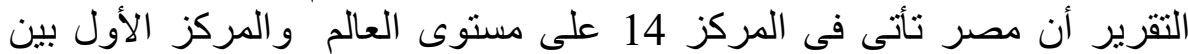
الدول العربية ( لوجين محمد، أنى في النرك).

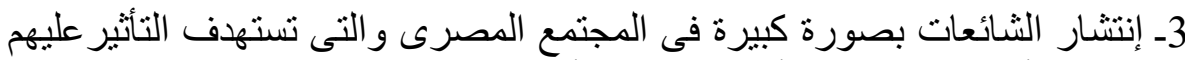

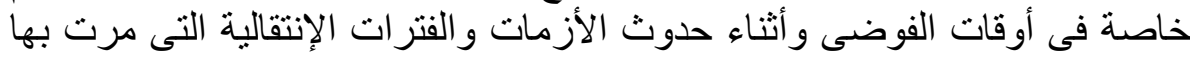

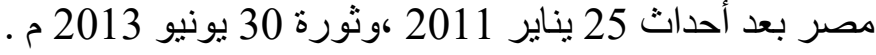

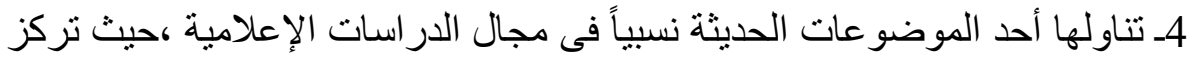

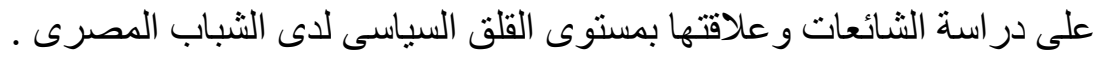

ثانياً :الأهية المجتمعية للاراسة

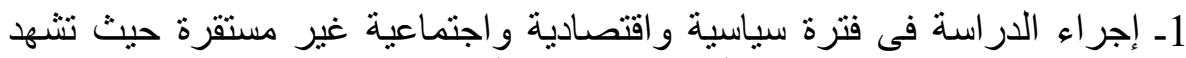

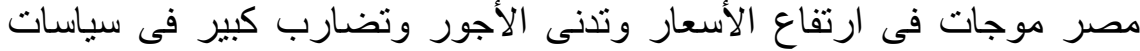

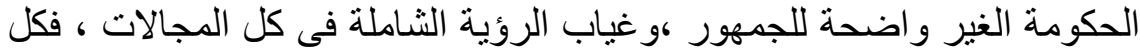

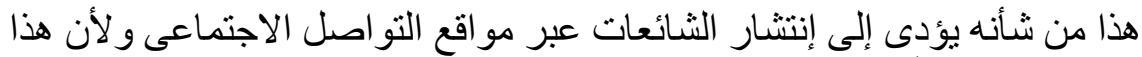

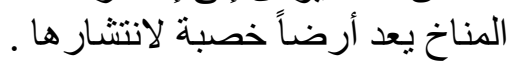

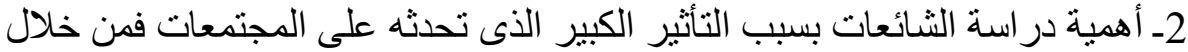

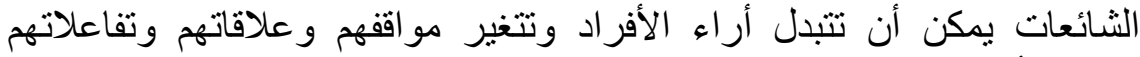

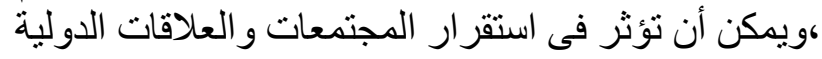

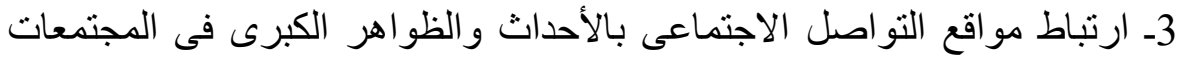

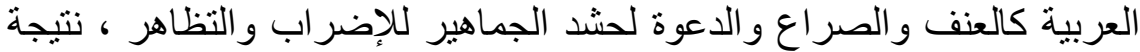

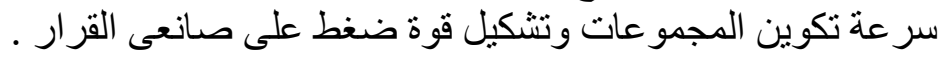

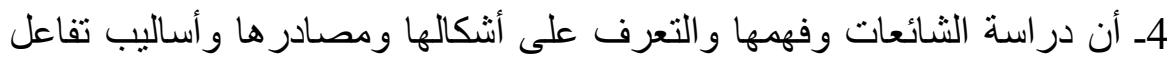

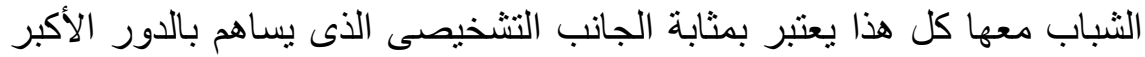

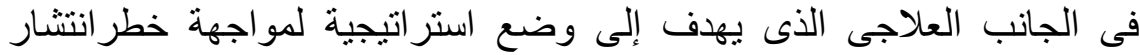

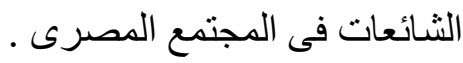

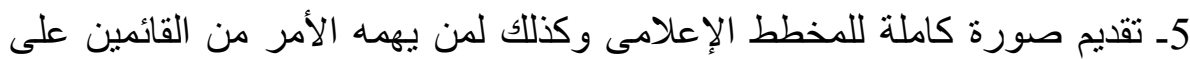

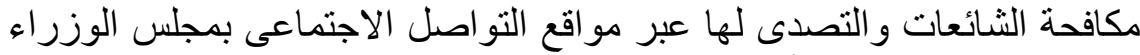

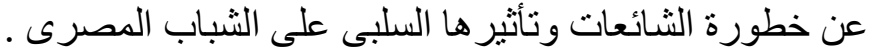


قسمت الباحثة الدر اسات السابقة إلى ثلاث محاور هى :الدار اسات وفقاً لمتغير انتشار

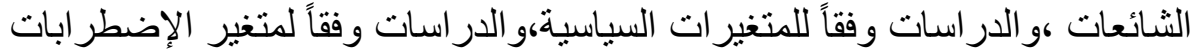

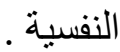

أولاً : الدراسات التى تناولت الثائعات عبر مواقع التواصل وتأثيراتها على الثباب

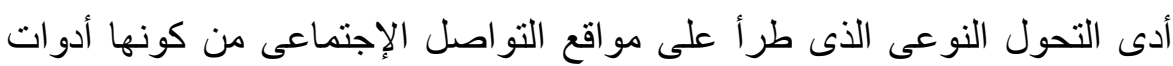

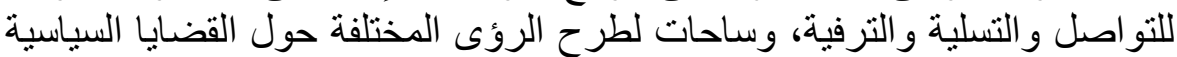

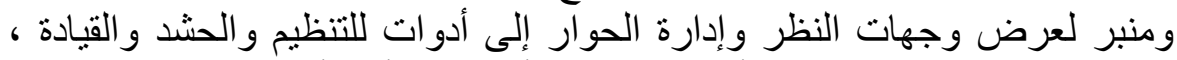

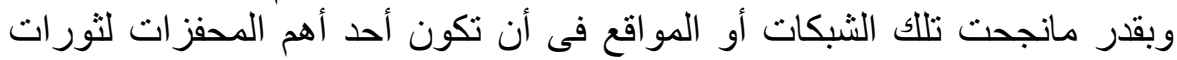

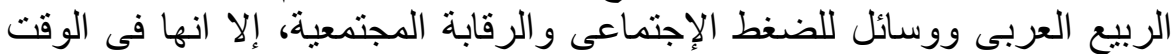

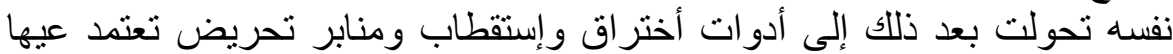

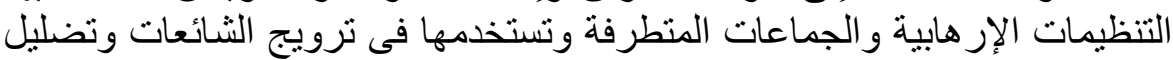

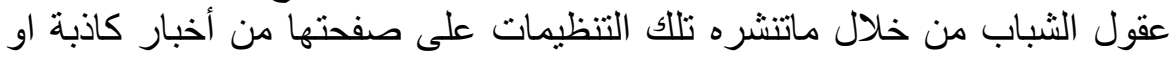

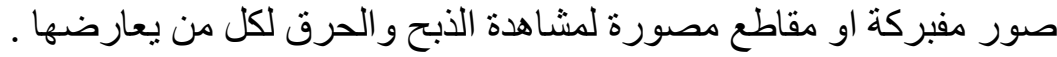

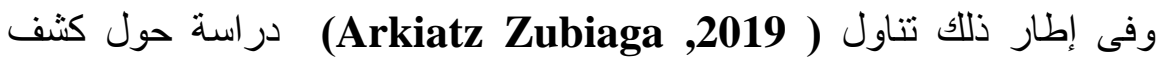

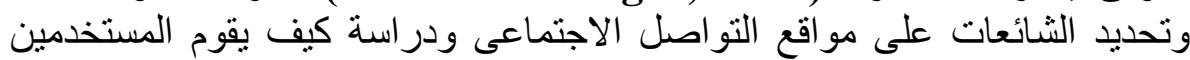

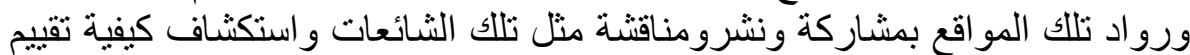

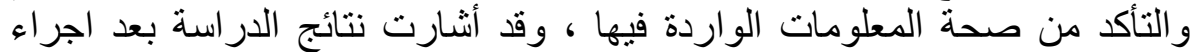
دراسة تحليلية لتلك المنصات أن هناك نوعين من الثائعات:هما الثائعات طويلة الثات التهات

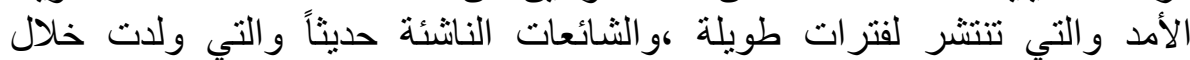
الأحداث سريعة الخطي مثل الأخبار العاجلة، فعندما يتم إصدار تقارير إخبارية الخبارية

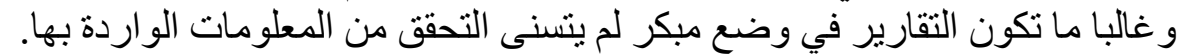

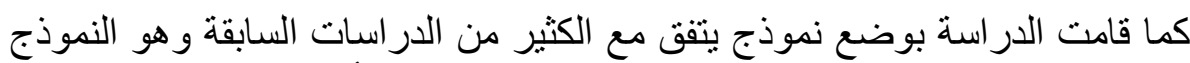

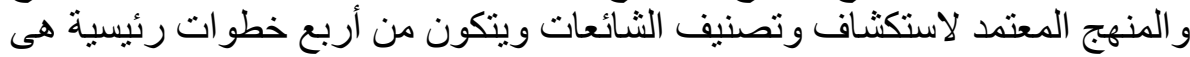

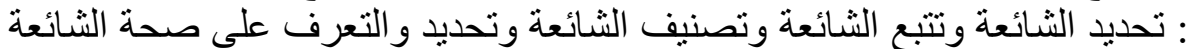

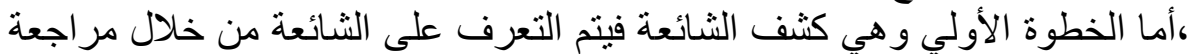

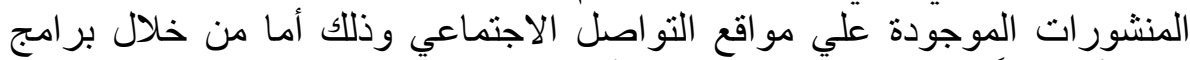
معينة أو يدوياً للتعرف علي الثائعات و الأخبار المزيفة.

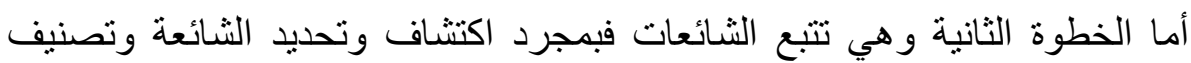

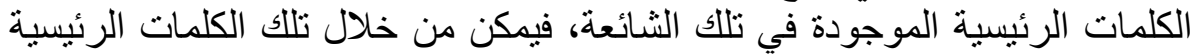

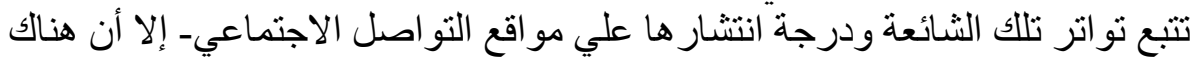

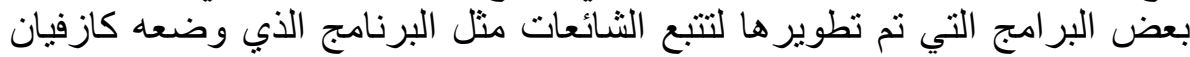




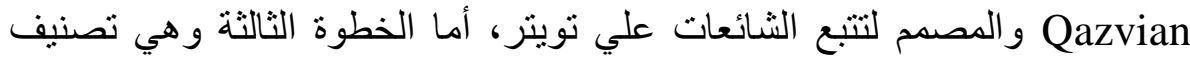

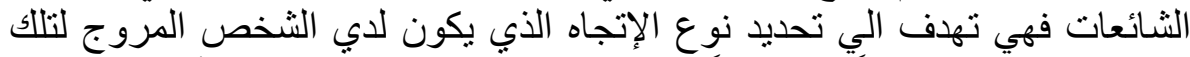

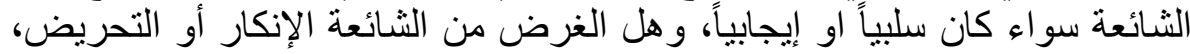

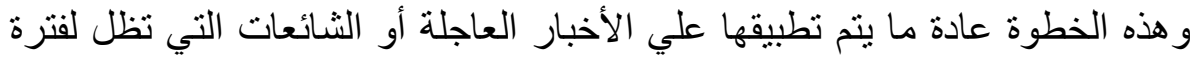

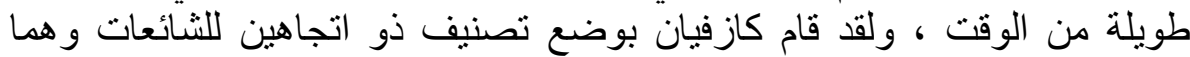

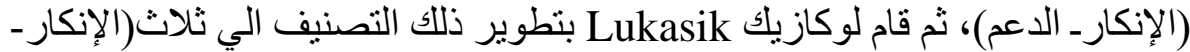

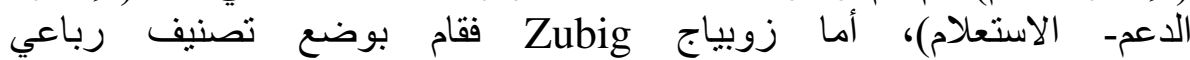
اللثائعات(الإنكار - الاعم- الاستعلام- التعليق).

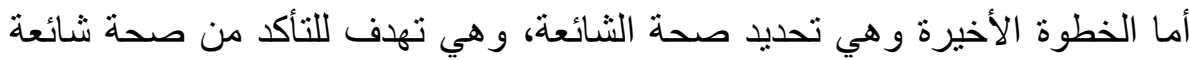

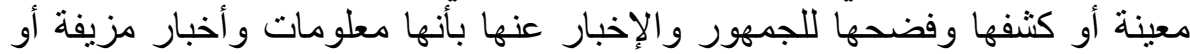

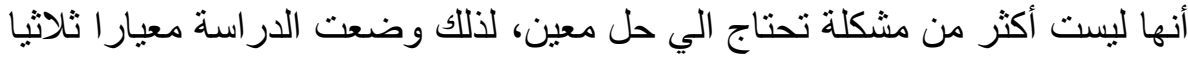

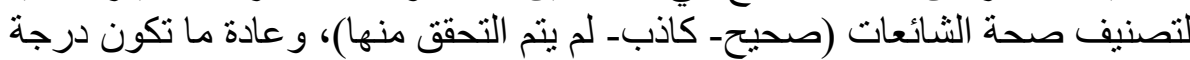
الصحة في تدرج معياري من0-10 و هنالك الكثير من البر امج التي تساعد في عملية

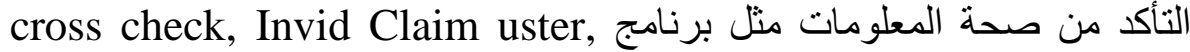
وبرنامج Una Hakika و هو برنامج كيني للتعامل مع الثائعات مزود بمحرك بحث لإليجاد الثنائعات

وفى إطار ذلك تناولت دراسة (Taeyoug Lee ,2018) نأثنير الثائعات على الشباب

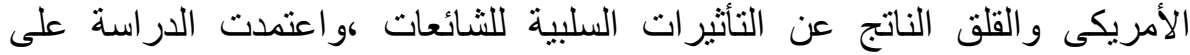

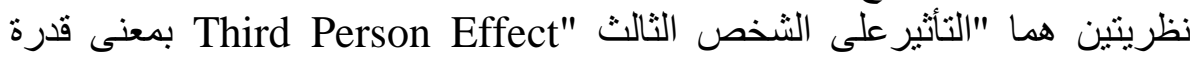

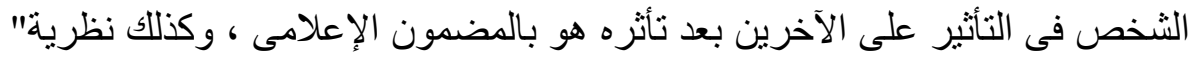

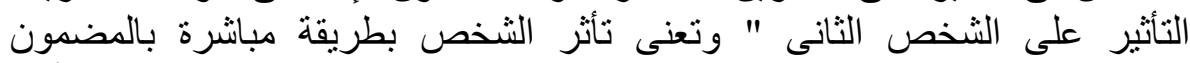

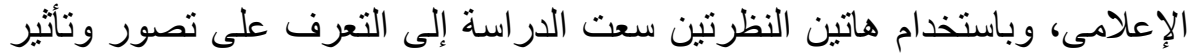

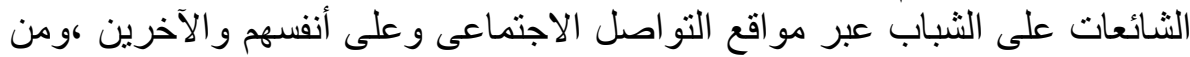

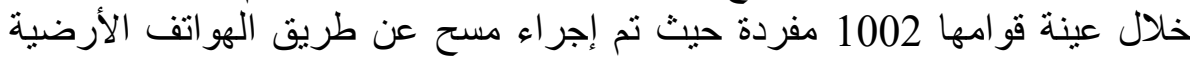
ل500 مفردة من تللك العينة ،وتوصلت الدراسة إلى قدرة الثباب على التى التعرف على التى

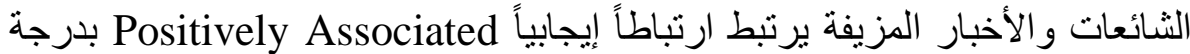
تأثنير تلك الثائعة على الثباب ،وبتطبيق نظرية Third Person Effect على الثيان تلكية

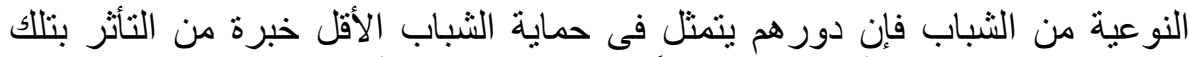

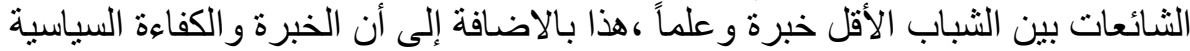

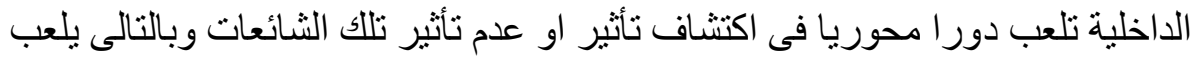

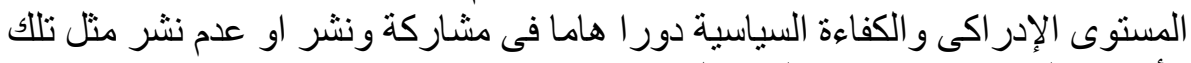
الأخبار على منصات مو اقع التواصل الإنل الاجتماعى. دواهي.

وتكملة لما سبق تناولت دراسة (Francis Bloch 2018) ألنواع الثاءع الثائعات

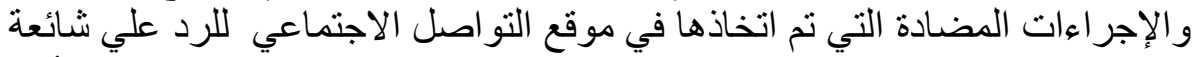

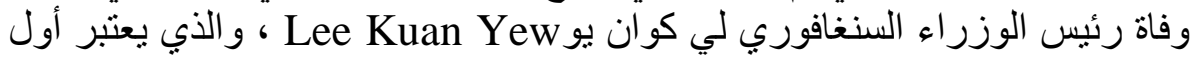




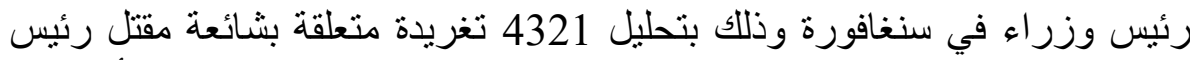
الوزراء، وبتحليل تلك العينة قام الباحث بتصنيف تللك التغريدات حيث ودئ وجد أن هناك

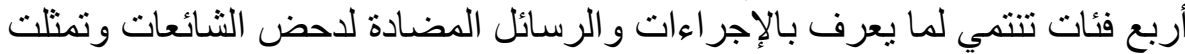

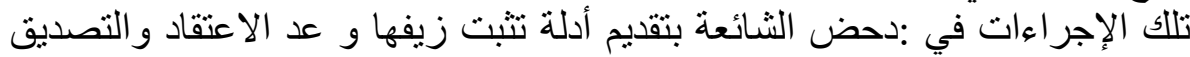

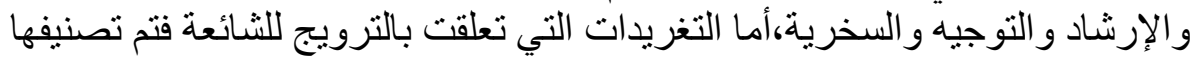
إلي فئتين هما :الاعتقاد وتقديم أدلة تؤكد صحة الثنائنة

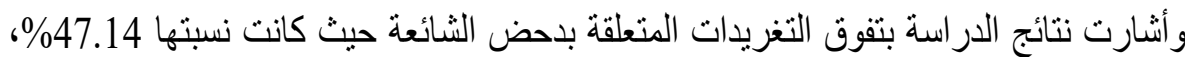

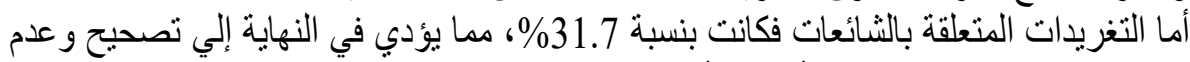

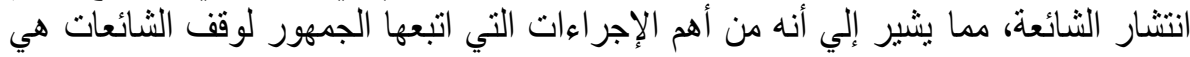

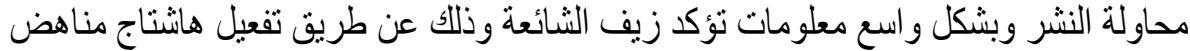

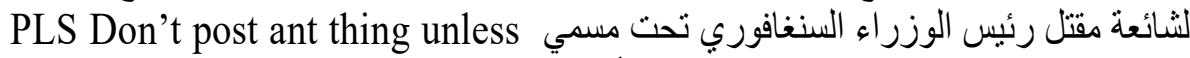

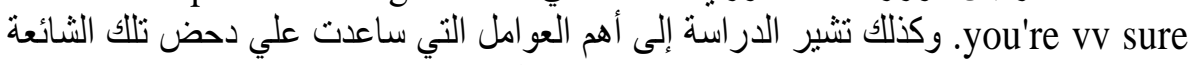

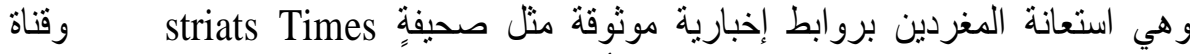
Channel news Asia

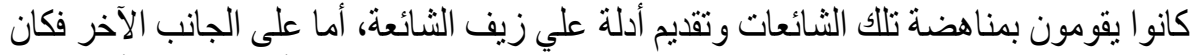

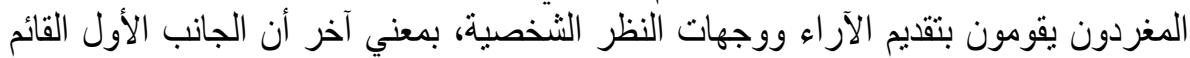

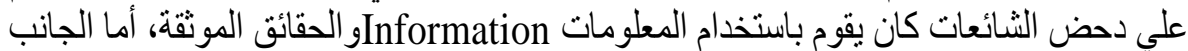
الآخر فكان يعتد علي وجهات نظر عاطفية emotion مما أدي في النهاية الي دحض الثنائعة الثنات المتعلقة بموت رئيس وزر اء سنغافورة.

وتناولت دراسة ( سالى بكر ،2018) الثائعات فى مواقع التو اصل الاجتماعى ودور التها

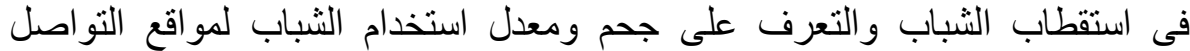

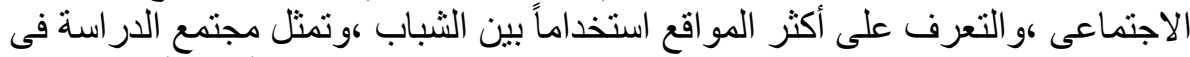

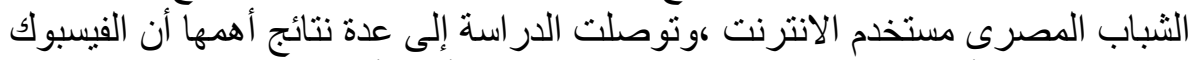

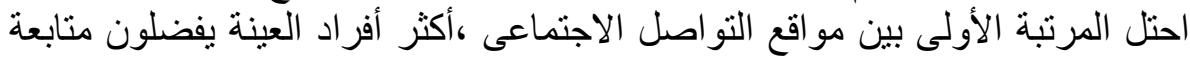

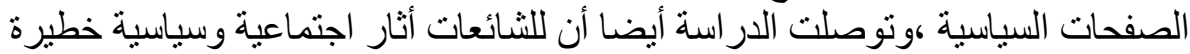
و أنها أصبحت من أهم أدوات حروب الصوب الجيل الروابع.

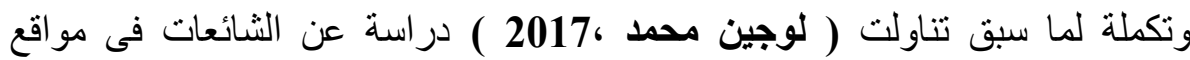

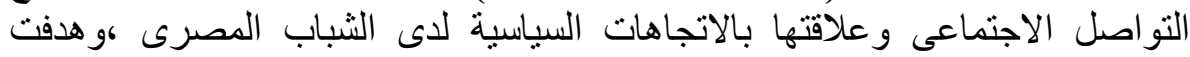

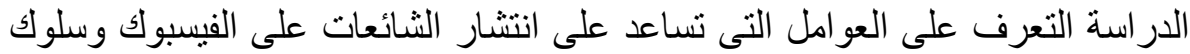
الشباب تجاهها ،وكذلك التعرف على العلاقة بين مستوى الاهتمام السياسى ومستوى لإنى

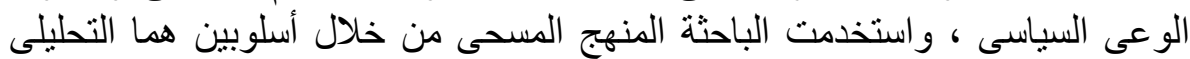

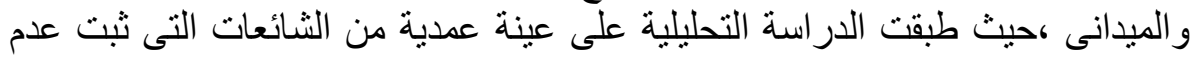

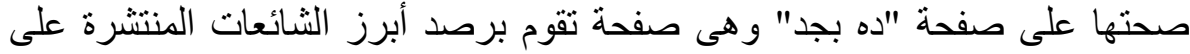

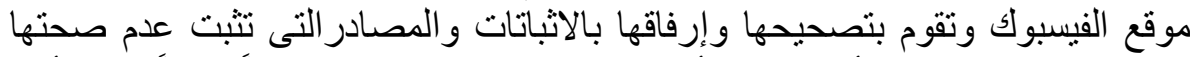

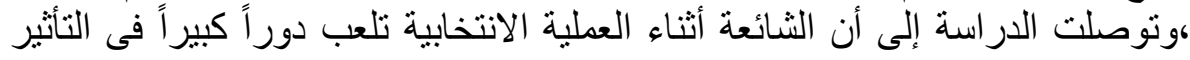




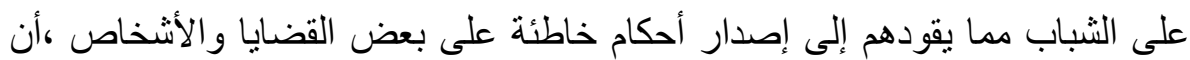

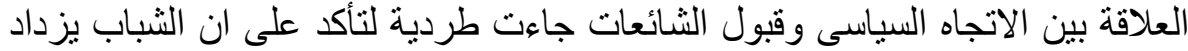

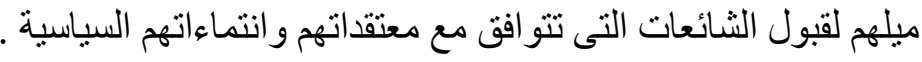
وهدفت دراسة ( 2017, kevin kolidle قياس تأثير ات الثائعات، فلقد انتشرت

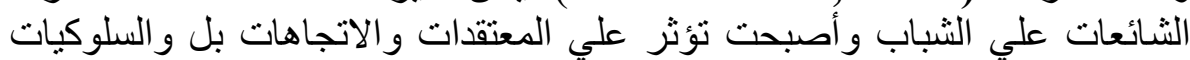

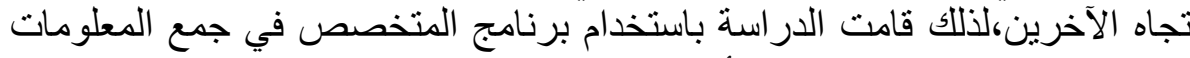

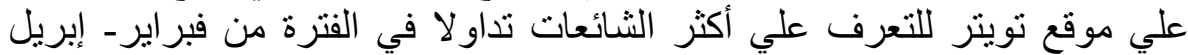

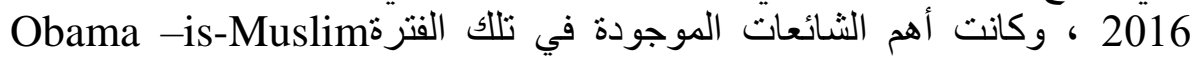

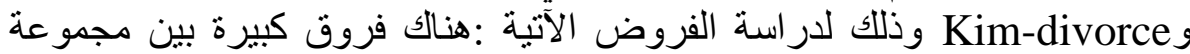

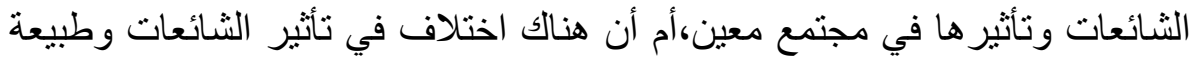

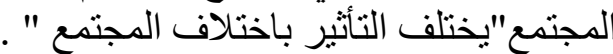

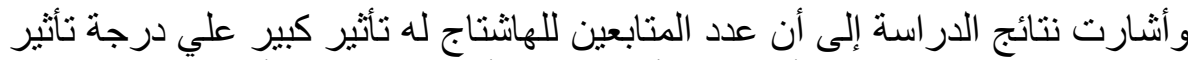

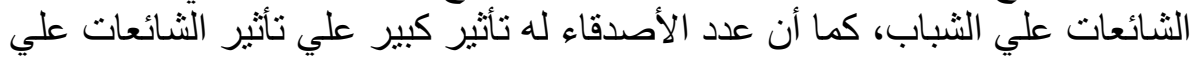

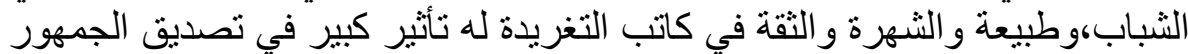

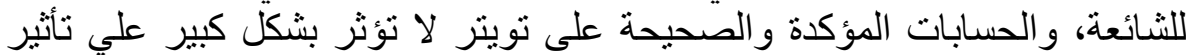

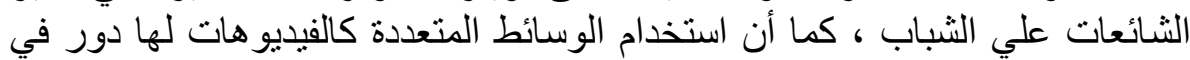

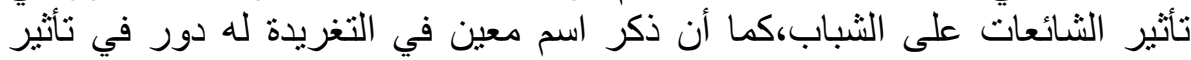

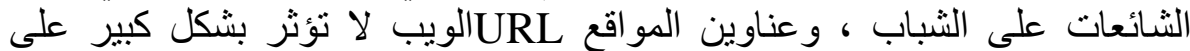

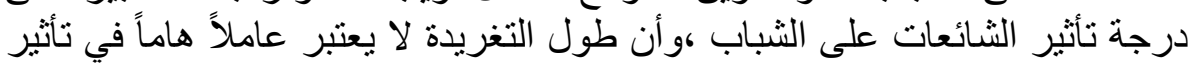

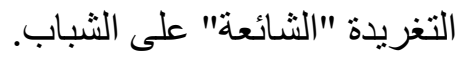

و أثنارت دراسة ( Benjamin Derr 2017 ) إلى أهمية الرسوم البيانية التفصيلية Preferential attachment graphs

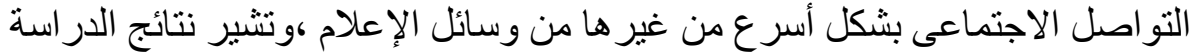

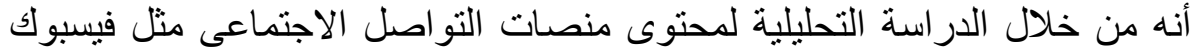

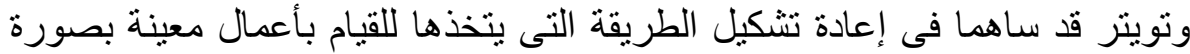

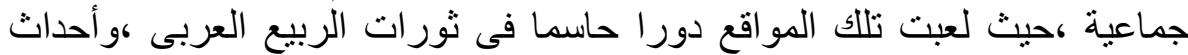

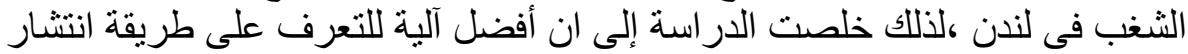

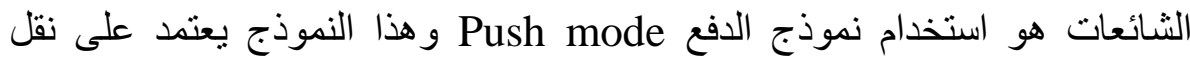

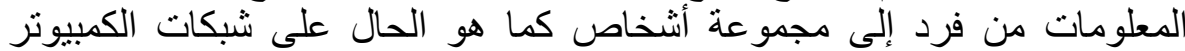

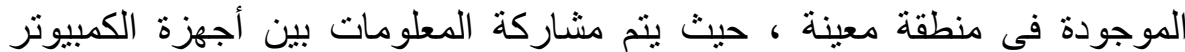

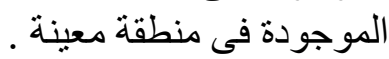

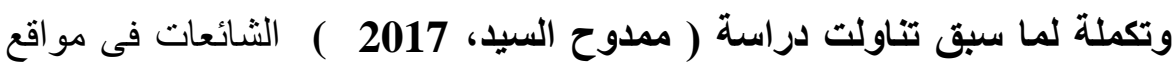

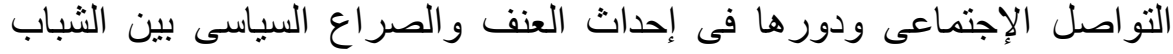

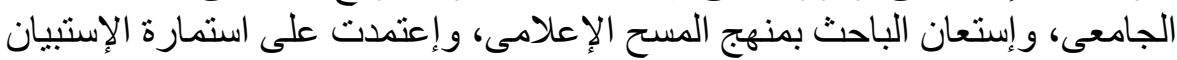




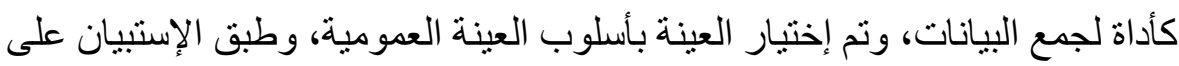

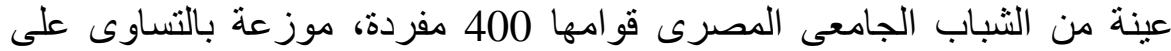

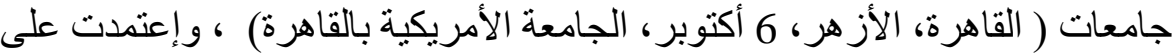

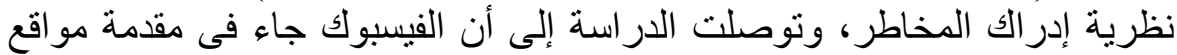

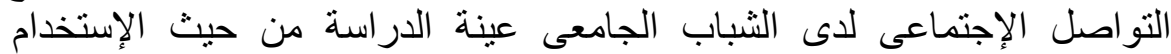

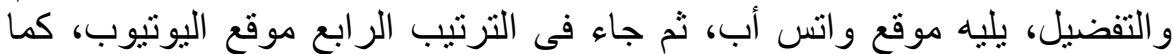

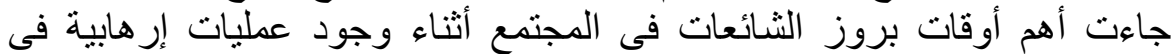

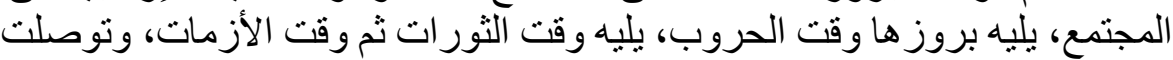

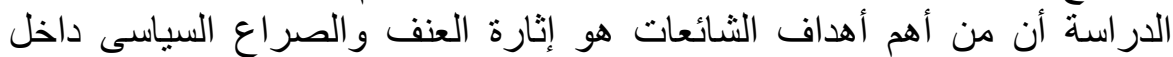

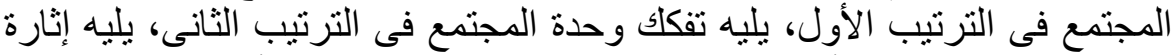
البلبلة والفوضى بين الأفراد في المجتمع، وجاء فيى الترنيب الأخير تدمير النظام القيمى و السلام المجتمعى.

وفى اطار ذلك تناولت دراسة ( "Maren H. Bjoergum , 2016) دور

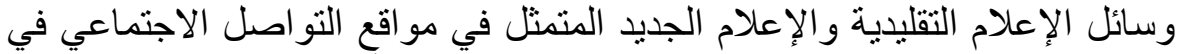

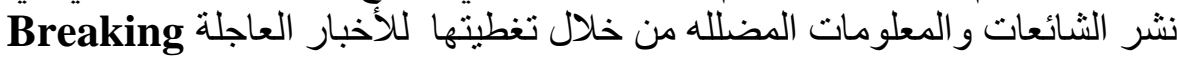

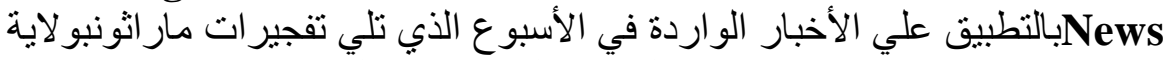

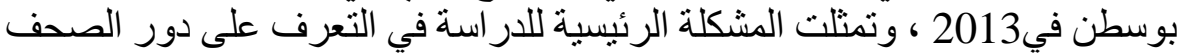

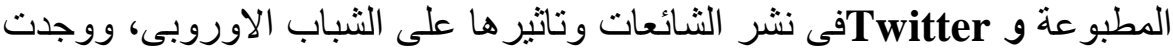

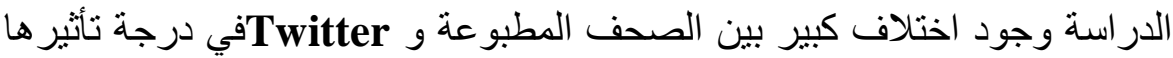

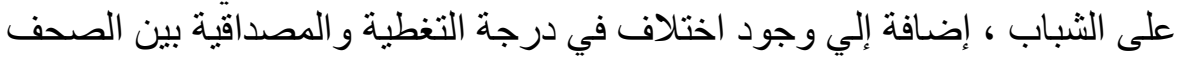
المطبوعة و Twitter وذلك لصالح الصحف المطبوعة والتي تحظي بمصداقية لدي دودي 58\% الجمهور، إضافة إلي موضو عيتها و عدم تحيز ها في تغطيتها لنأحداث، حيث

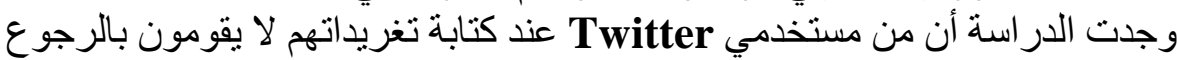

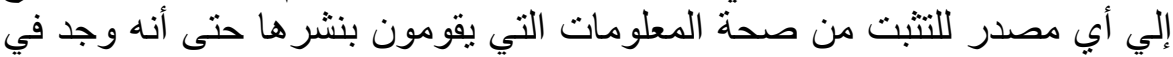
كثير من التغريدات علي Twitter تعنمد في الأساس علي مصادر تنتسب إلي إني الصحف المطبو عة مما ينفي أن Twitter يعتبر مصدر الرئيسيا للمعلومات، بل النها تم وصفTwitter بأنه وسيلة لنشر الأكاذيب والمعلومات المضللة Venue for

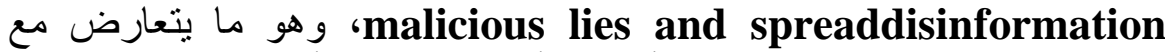

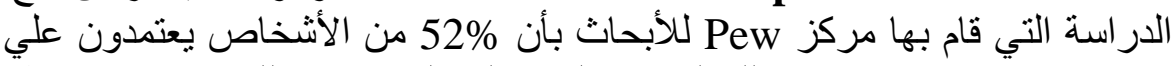

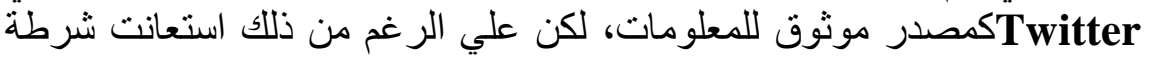
بوسطن بTwitter لنشر المعلومات وتطور ات تفجير ات بوسطن للجمهور.

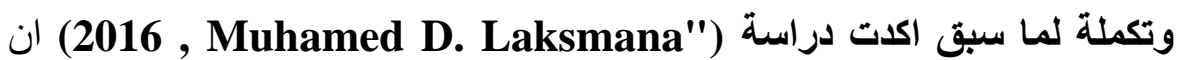

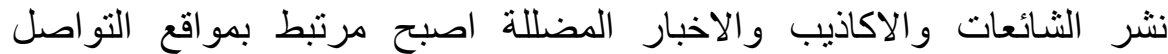

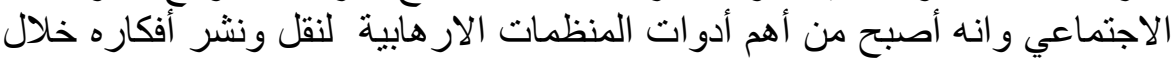




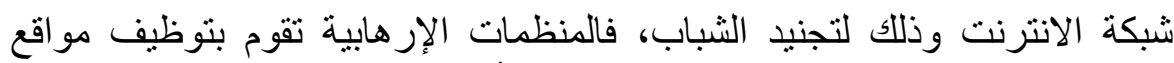
التو اصل الاجتماعي للقيام بحملات واسعة لنشر أيدلوجياتها.

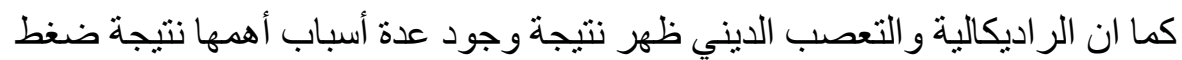

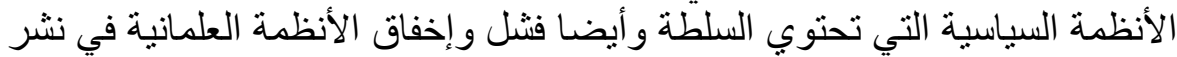

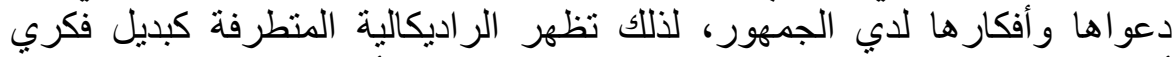

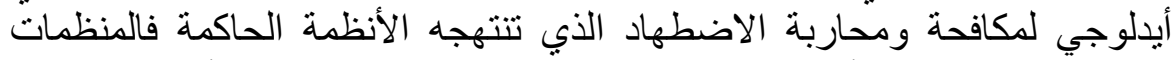

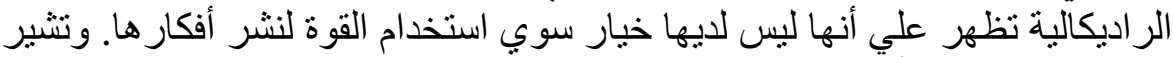

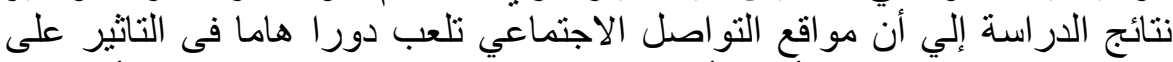

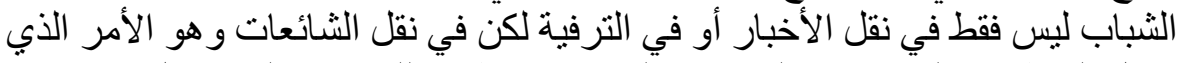

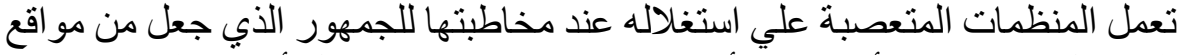
التو اصل الاجتماعي أداة ذات تأثير كبير علي الثباب في تقبل أفكار تلأك المنظمات

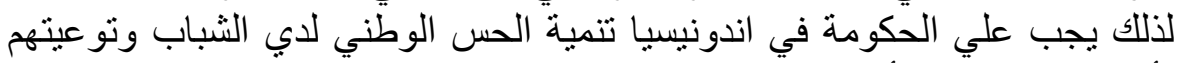

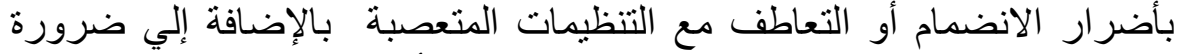
مر اقبة المضمون الإعلامي سواء ألعاطف في الإعلام التقلبدي أو الحديث.

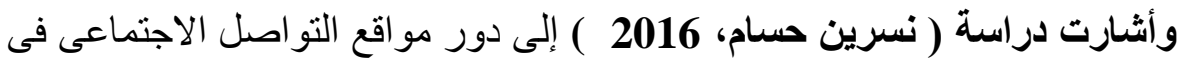

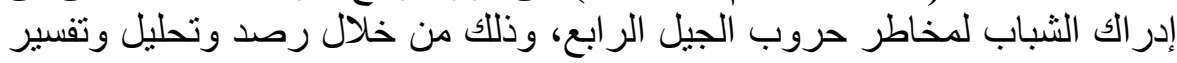

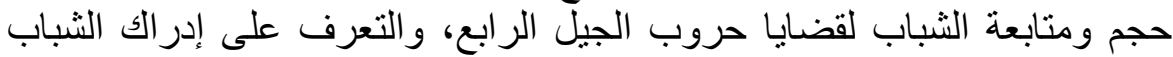

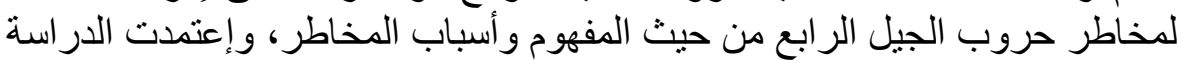

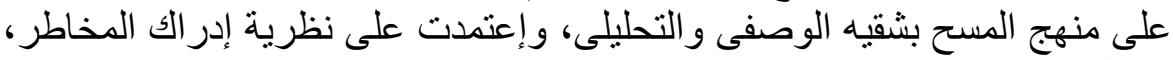

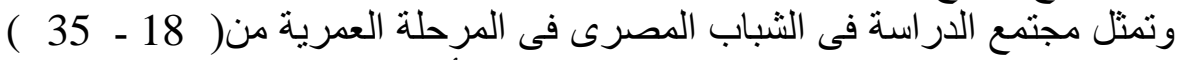

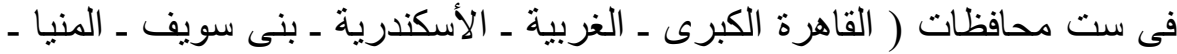
سوهاج ) حيث بلغ حجم العينة 300 مفردة، وتم إختيار المبحوثين بطريقة العينة العينة العدية، وتوصلت الدراسة إلى أن أكثر من

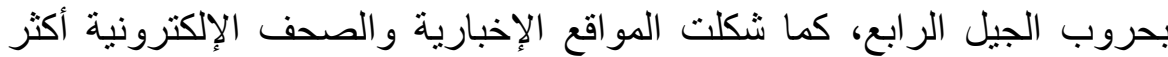

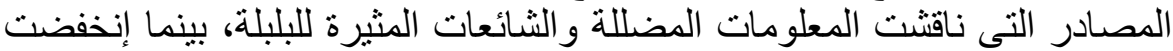

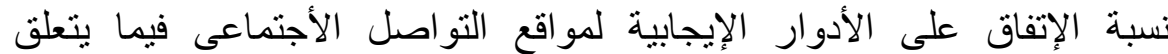

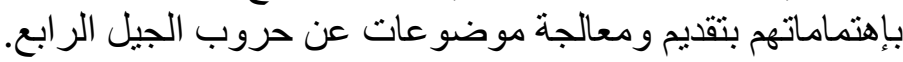

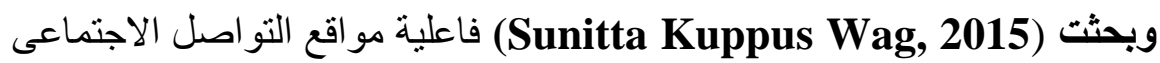

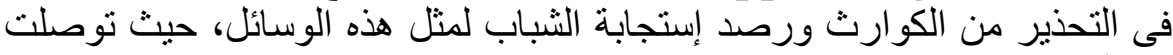

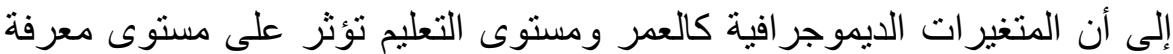

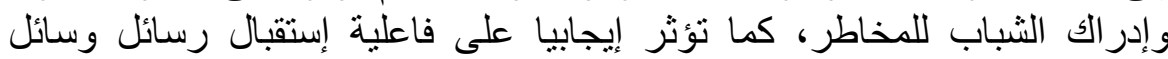

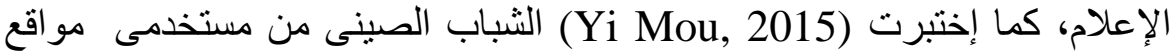

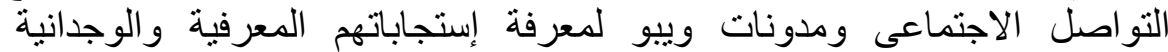

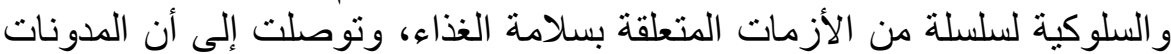

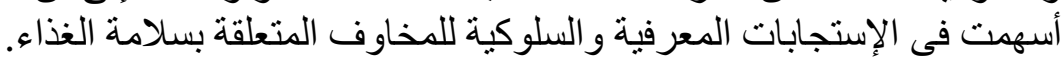




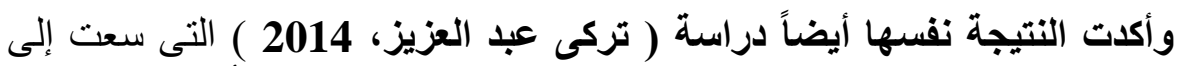

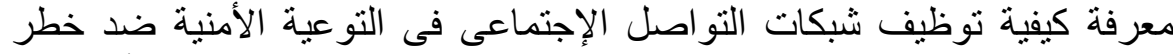

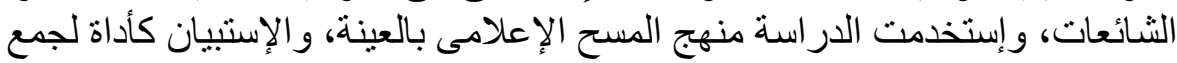

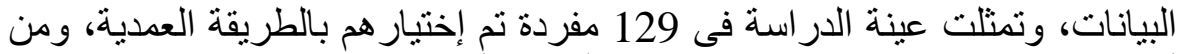

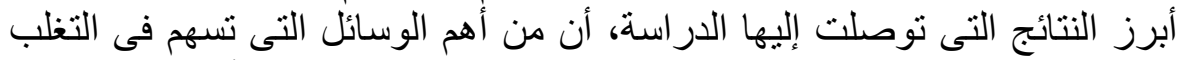

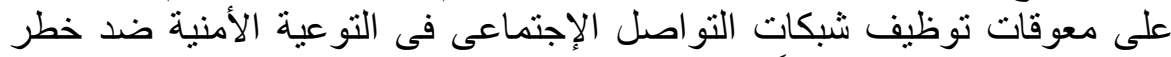

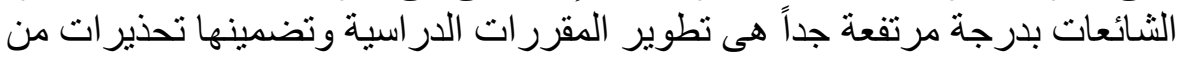

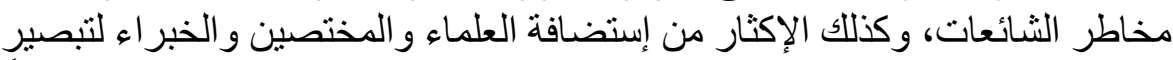
مستخدمى الثبكات الإجتماعية بمخاطر الثنائعات المختلفة على المجتمع سياسياً و إجتماعياً ودينياً.

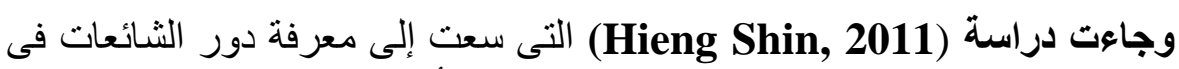

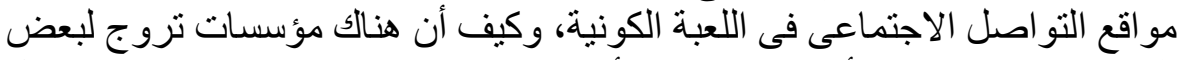

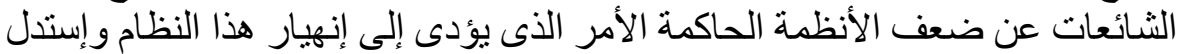

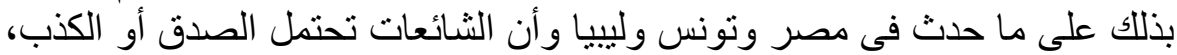
وأن الناس أثثاء إنتشار الثائعات تكون همهم الأكبر.

ثانيا : الدراسات التى تناولت القلق السياسى :-

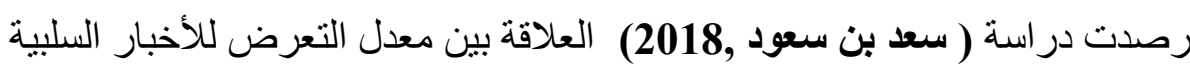

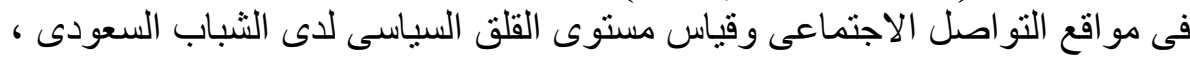

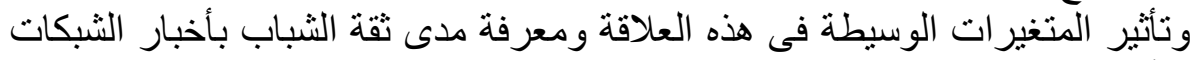

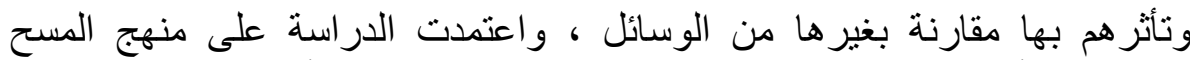

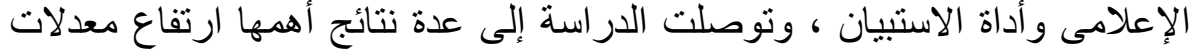

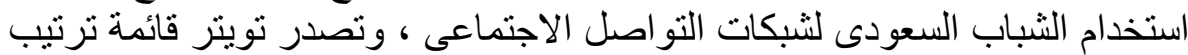

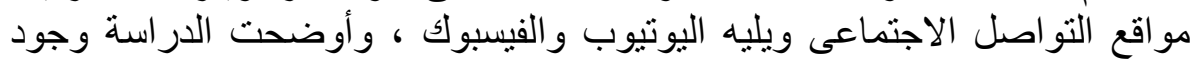

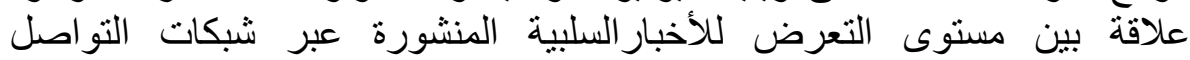

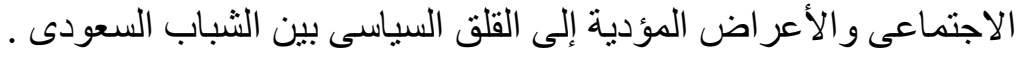

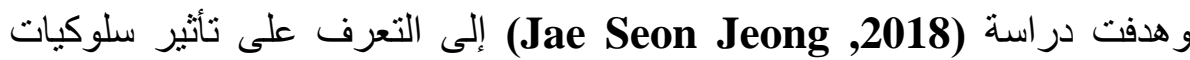

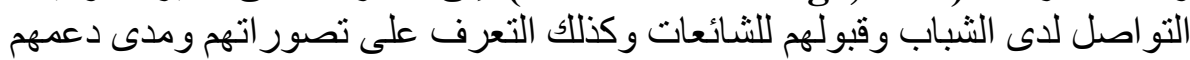

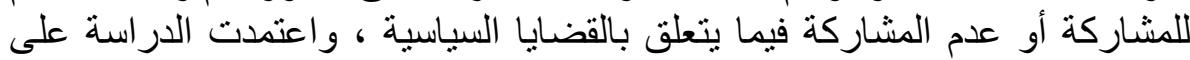

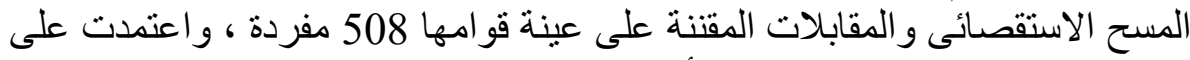

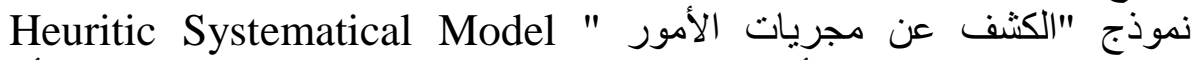

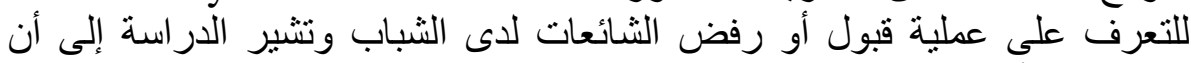

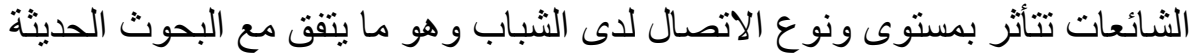
،وان الثائعات توجد لسد الثغرات وذلك عند افتقار المعلومات الدقيقة ، حيث يفتقر 


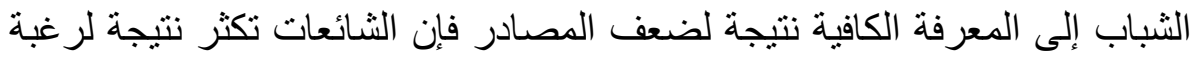

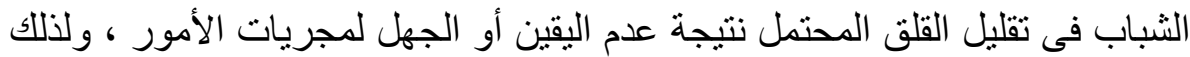

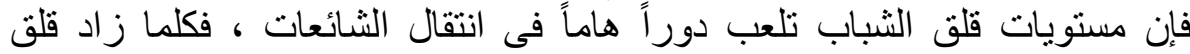

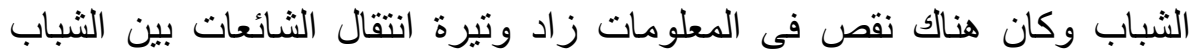

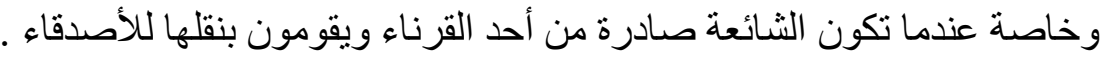

وتكملة لما سبق أجرى (Killy . A Rodamer 2017) دراسة عن الحملات

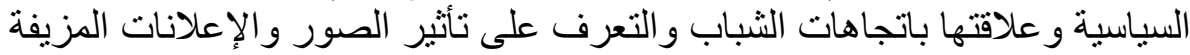

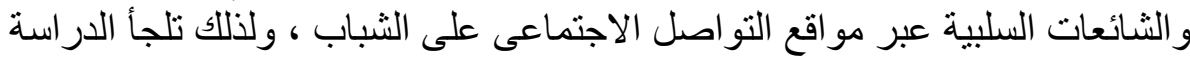

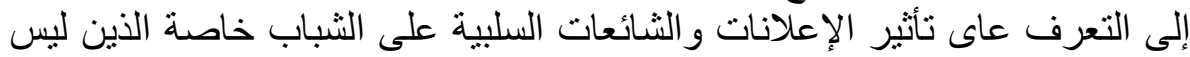

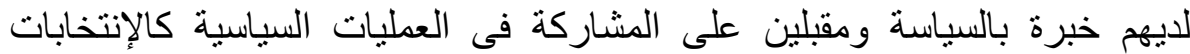
الرئاسية أو ما يعرف First - Time Voters ونم تطبيق الدراسة المسحية على الإنى

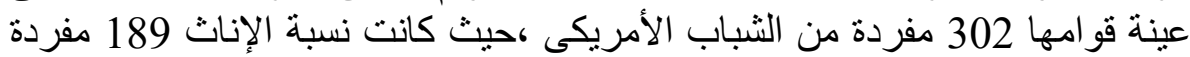

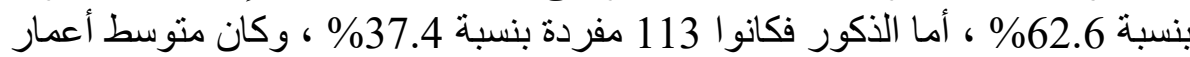

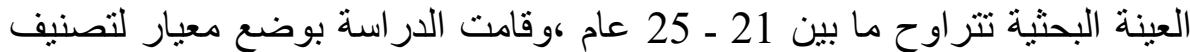

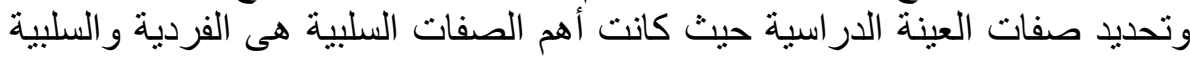

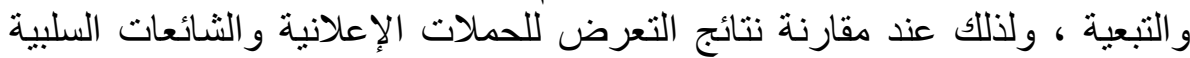

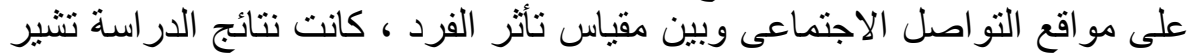

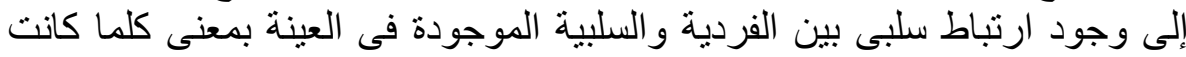

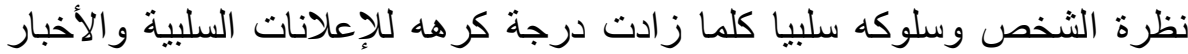

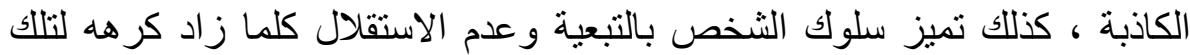
الأخبار و الثائعات السياسية السلبية.

و إضافة لما سبق تناولت دراسة ( نورا مصطفى ،2017 ) الثائعات السياسية على

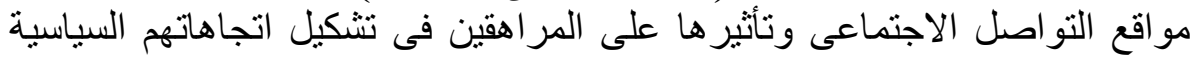

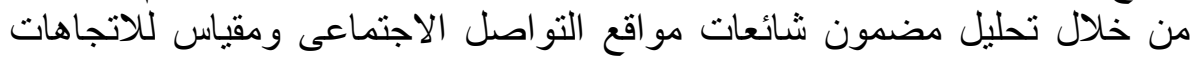

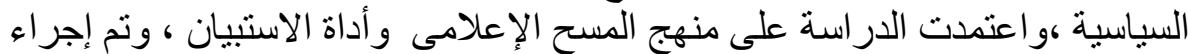

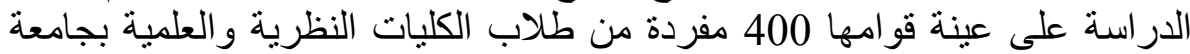

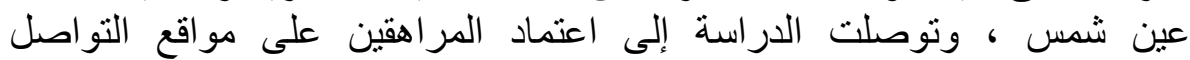

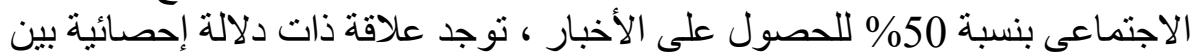
تعرض المر اهقين لثائعات مواقع التو اصل الاجنماعى واتجاهاتهم السياسية .

وأثارت دراسة ( Haifeng Hung 2014 ) إلى التأثيرات السياسية لانتشار

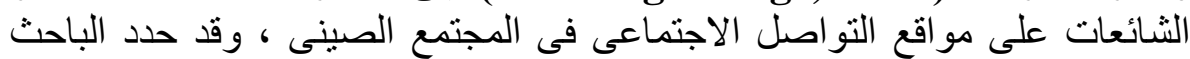

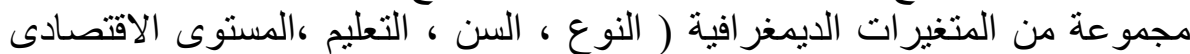

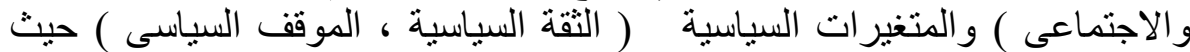

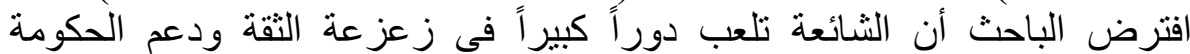

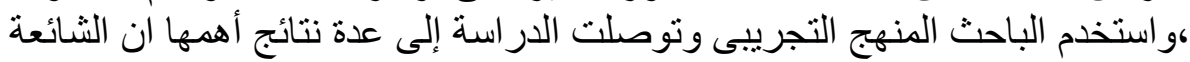


تؤدى إلى نقص النقة فى سياسات الحكومة،وجود علاقة ذات دلالة إحصائية بين

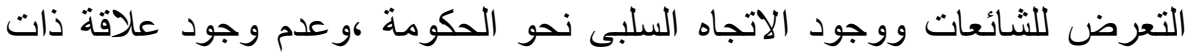
دلالة إحصائية بين مستوى التعليم وقبول الثنائعة .

وتكملة لما سبق تناول ( Adam J. Berinsky , 2011) العوامل التى ولى تؤثر على اتجاهات الأفراد نحو الثائعة السياسية ومعرفة الأثار المترنبة

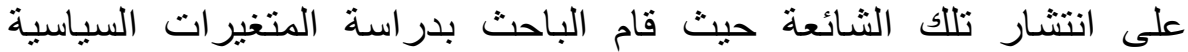

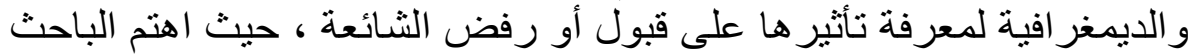

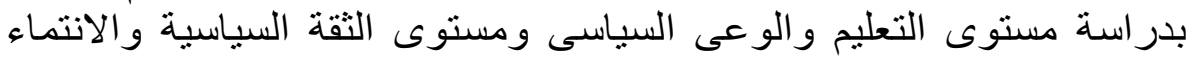
الحزبى ، وطبق الباحث استبيانين عبر الانترنت حيث شملت التئت العينة 800

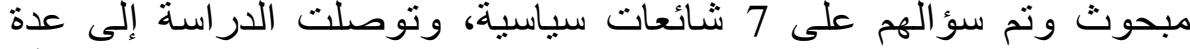

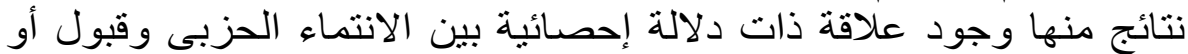

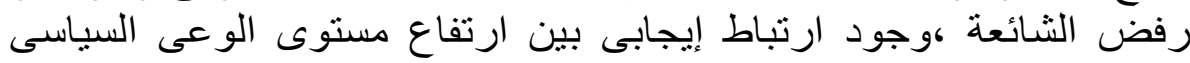
ورفض الثنائعات ،وجود ارنباط إيجابى بين انخفاض مستوى الثقة السياسية وقبول الثائعة .

ثالثاً : الاراسات التي تناولت العلاقة بين مواقع التواصل الاجتماعى والإضطر ابات

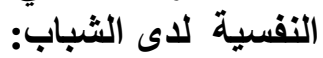

وفى إطار ذللك أجرى (أحمد سعيد المهدى ،2018) دراسة عن المحددات النفسية

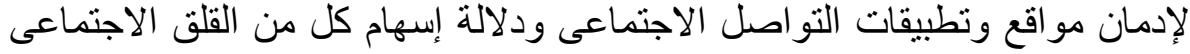

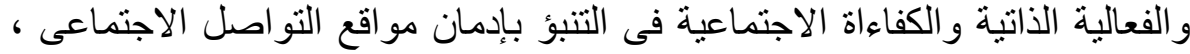

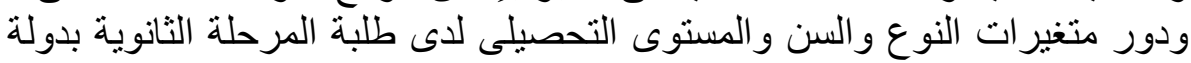

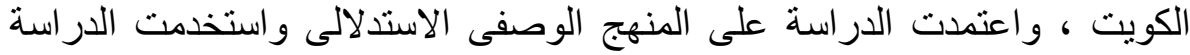

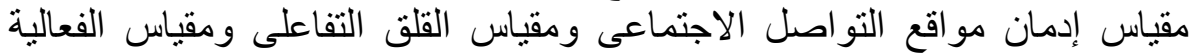

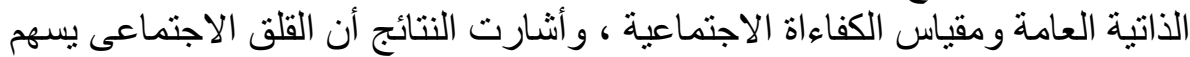

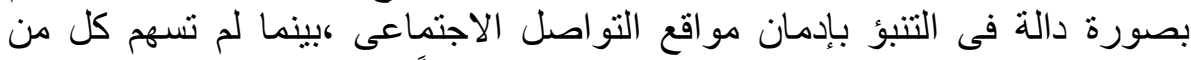

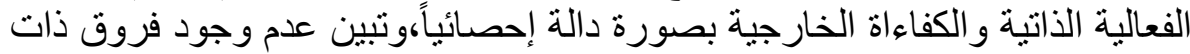
دلالة إحصائية بين النوع والمستوى الدراسى فى كل من إدمان مواقع التئ التواصل

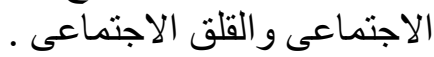

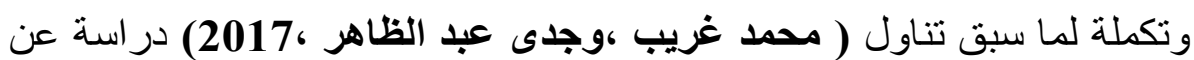

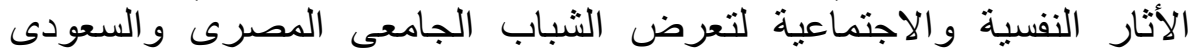

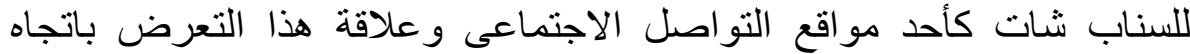

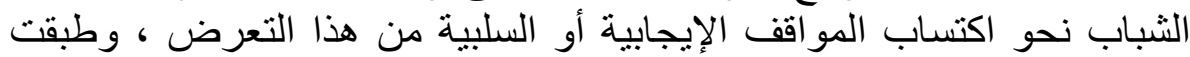

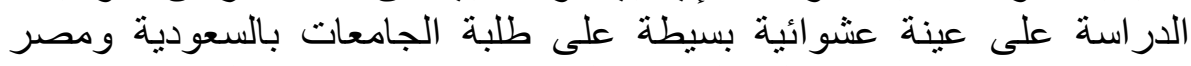
قو امها400 مفردة ، وتوصلت الدر اسة إلى وجود فروق ذات دلاتية دلالة إحصائية بين

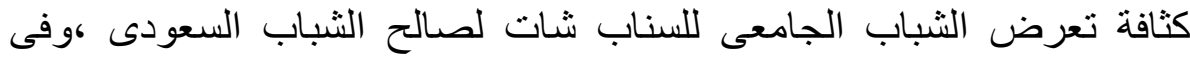


التخلص من القلق و الملل و الترفية والتسلية لصالح الثباب المصرى ، وجود فروق ذات ذلالة إحصائية بين الأثار النفسية الإيجابية والسلبية والئية والأثار

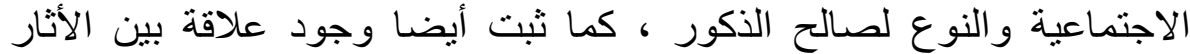

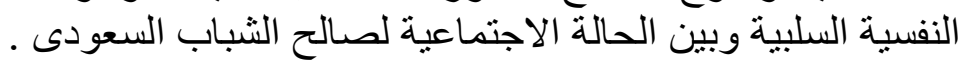

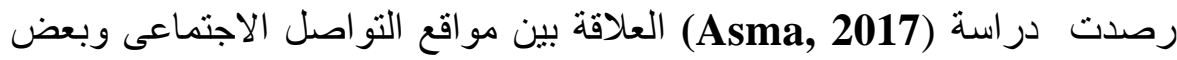

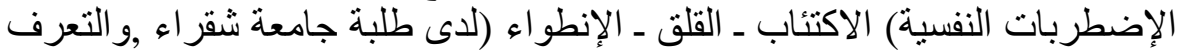

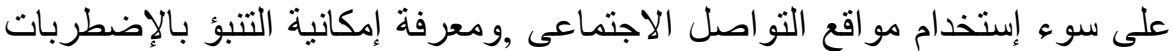

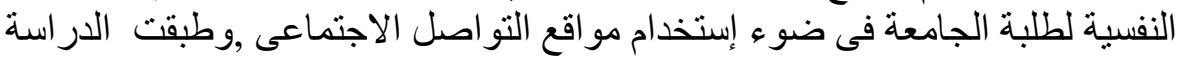

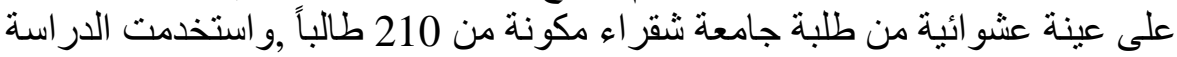

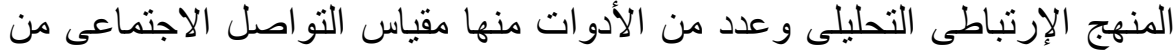

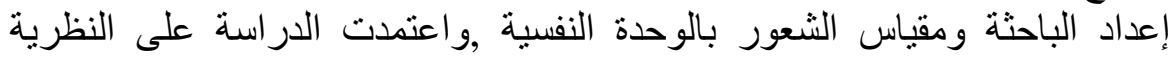

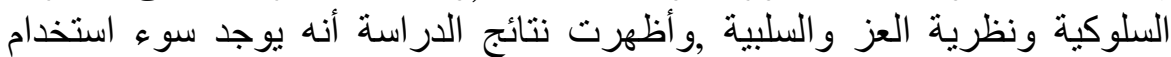

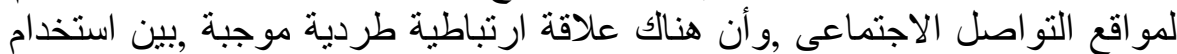

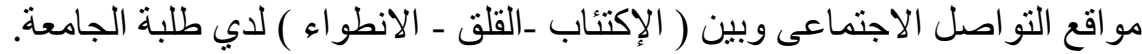
وتناولت دراسة (Garett, Liusean, 2017) العلاقة بين مواقع التواصل فواعل

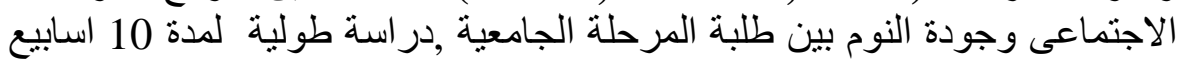

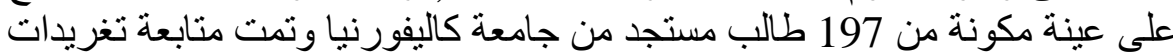

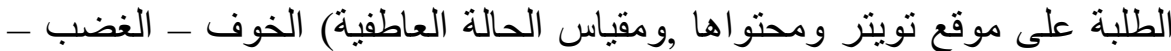

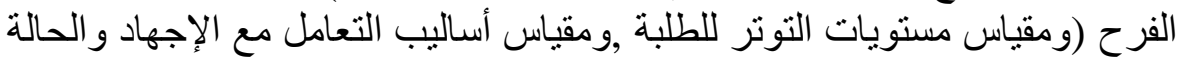

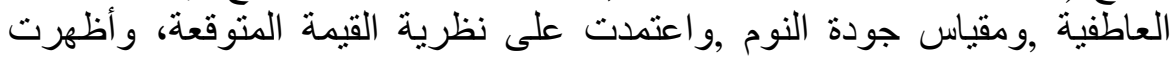

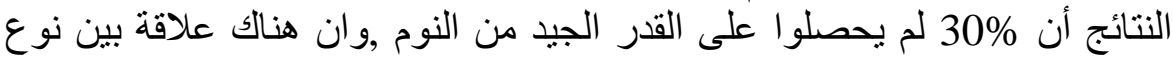
التغريدات وحالتها العاطفية ووقتها وجودة النوم عند طلبة الجامعات.

وتكملة لما سبق تناولت دراسة ( نسمة على، 2017 ) العلاقة بين المخدرات

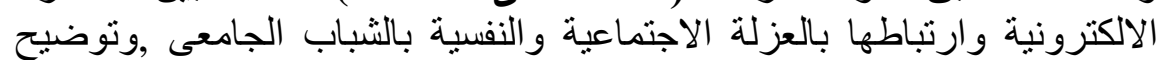

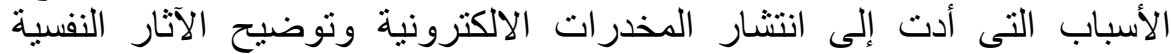

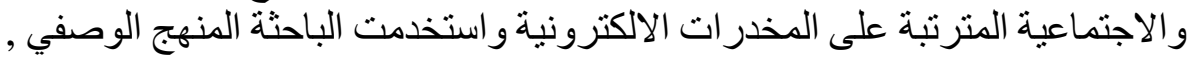

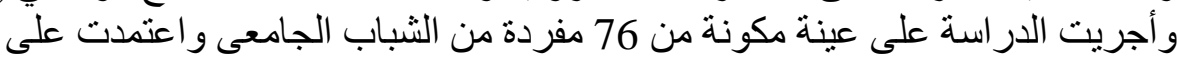

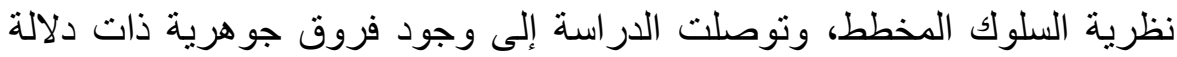

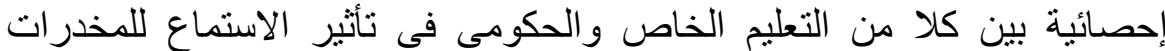

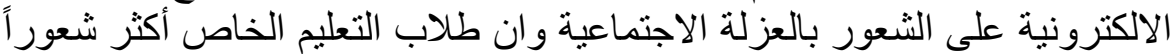

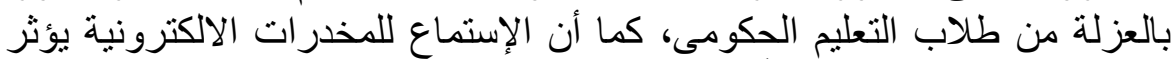
على التحصيل الدر اسى تأثير آ سلبا. وأثارت دراسة (Mahmoud Farooq, 2016) إلى معرفة تأثير بعض متغيرات الثخصبة على إدمان الفيس بوك، ومعرفة العلاقة بين إدمان الفيسبوك والعو امل الخمسة 


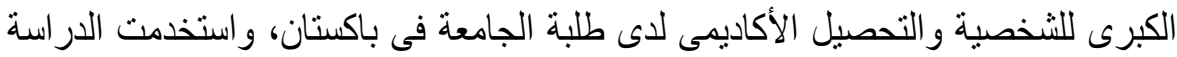

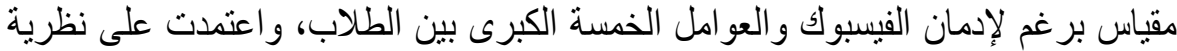
التنافر المعرفى، وتكونت العينة من 150 طالب، وتوصلت الدار اسة إلى وجود علاقة أرنباطية سالبة بين إدمان الفيس بوكئك و التحصيل الدر اسىى.

ورصدت دراسة ( محمد عبد المنعم، 2015 ) دوافع استخدام طلبة الجامعات الإني

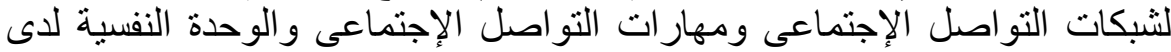

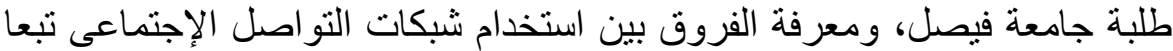

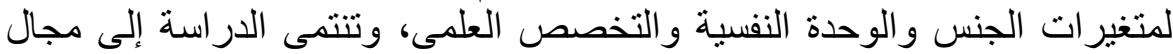

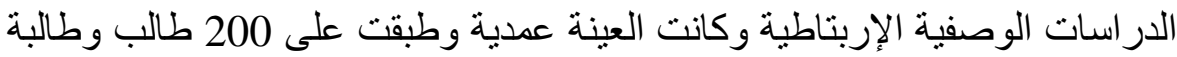

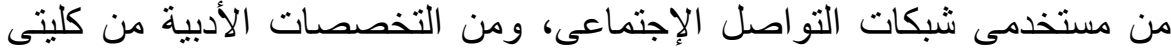

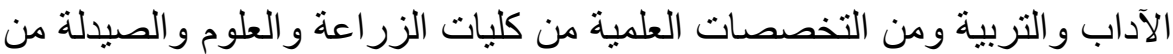

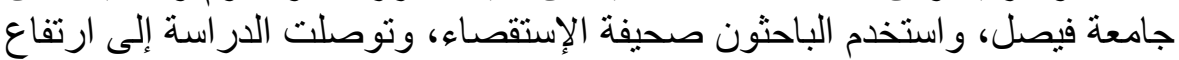

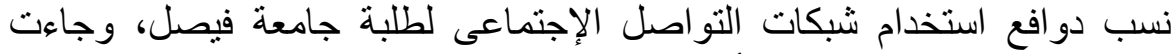

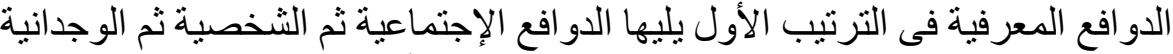

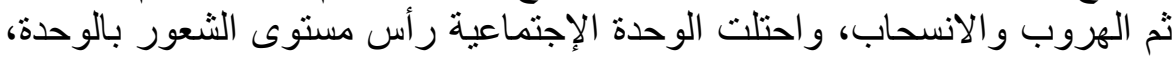

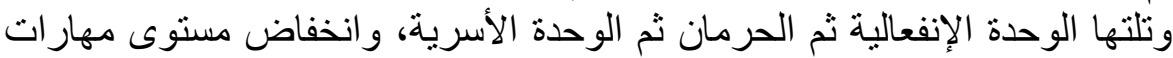
التو اصل لاى مستخدمى شبكات التو اصل الإنل الإجتماعى.

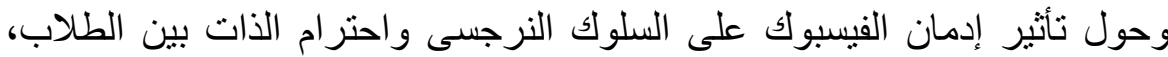
هدفت در اسة (Sadia and Maheen , 2015) إلى التحقير التحقيق في العلاقة بين إدمان الفيس بوك وكلا من النرجسية واحتر ام الذات وقد أجريت الدر اسة فئ في الفترة

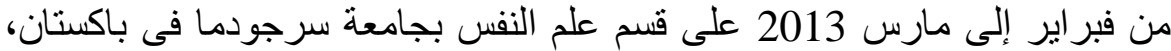

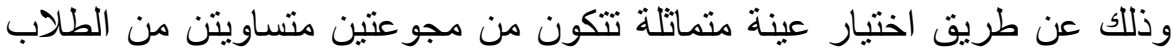

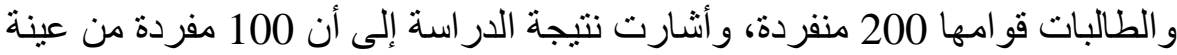

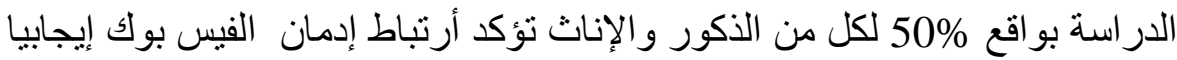
مع النرجسية لايهم، كما تؤكد ارتباط إدمان الفيس بوك الأبل سلبيا مع إحتر ام ذاتهم.

وتكملة لما سبق تتاولت در اسة (Ramesh and Sonaksh, 2015) إدمان الفيس

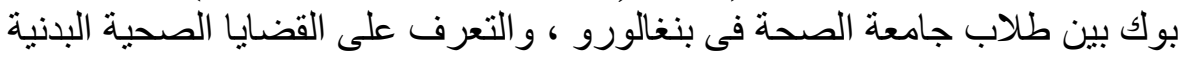

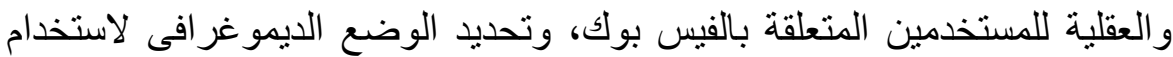
العينة للفيسبوك، وقد اجريت الدر اسة فى الفترة من مايو حتى يوليو 2013 على لإئ عينة

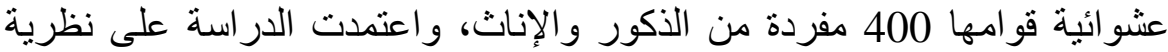

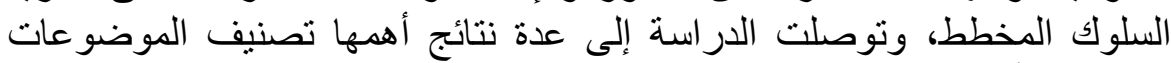

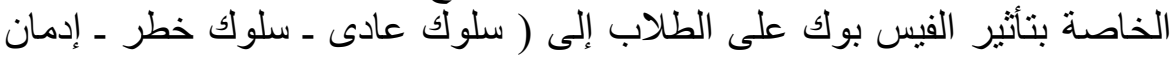
الفيس بوك) وتثير نتائج الدراسة إلى أن

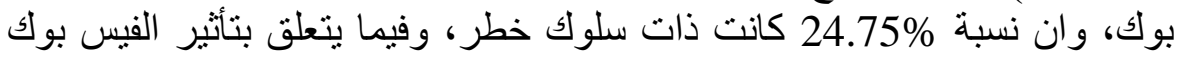


على الصحة البدنية للطلاب، فقد أشار 32\% من الطلاب انهم يعانون من إجهاد

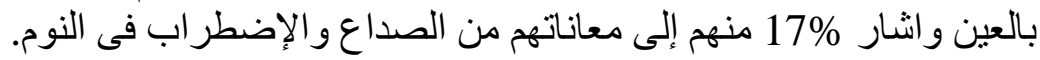

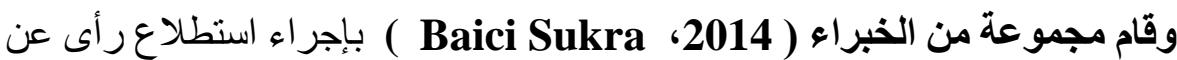

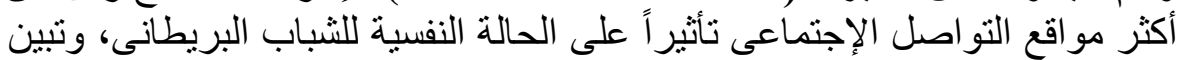

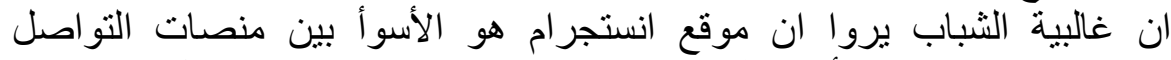

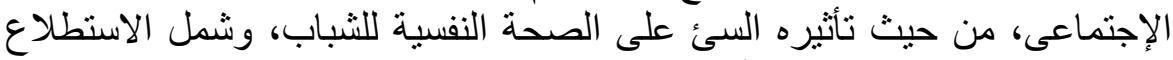

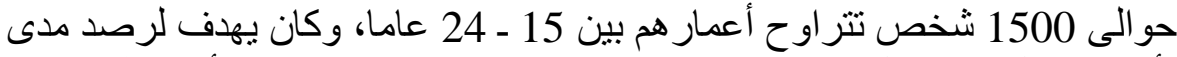

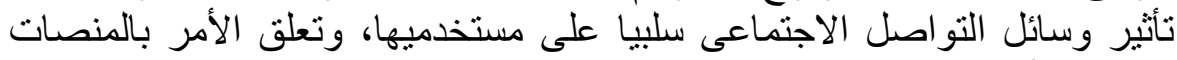

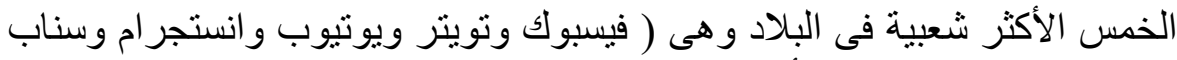

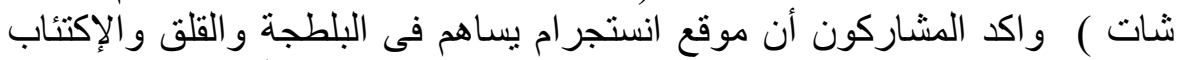

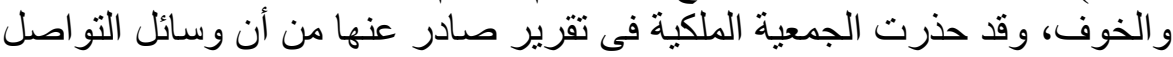

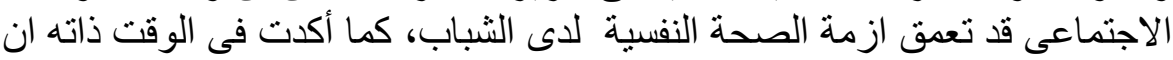

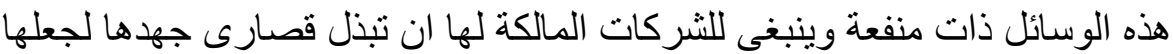

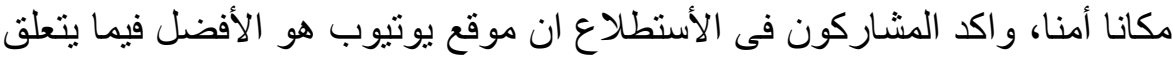
بالصحة النفسية يليه تويتر ثم فيسبوك في الكان.

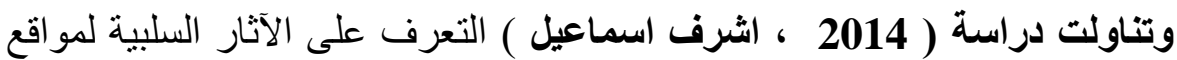

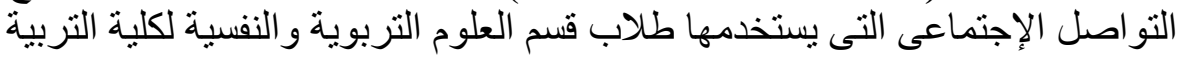

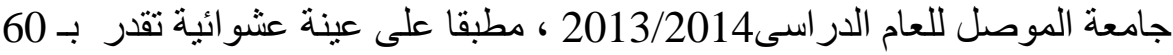
طالبا، مستخدما مقياس الآثار السلبية، ولتحديد آراء شريحة من طلبة الجامعات التاتية

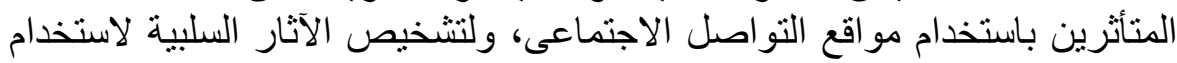

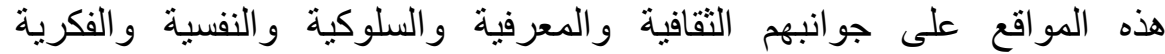

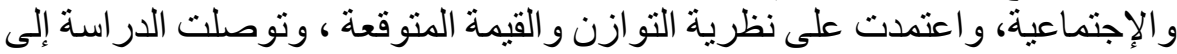

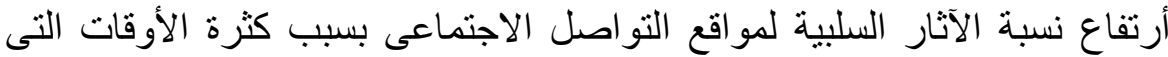

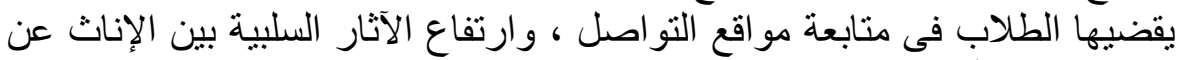
الذكور، ومنشأ ذلك من طبيعة المجتمع العر اقى عمو مأسا.

وبالنسبة لتأثير إدمان الفيسبوك لدى المدارس الثانوية بتركيا، اجرى الباحثان ( Baicio ), Tirgaki , 2014

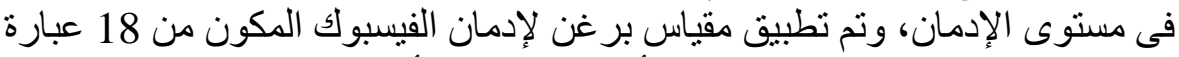

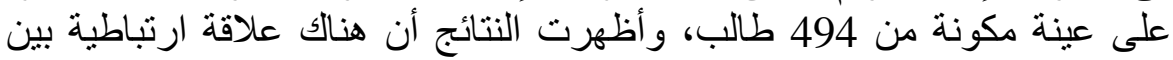

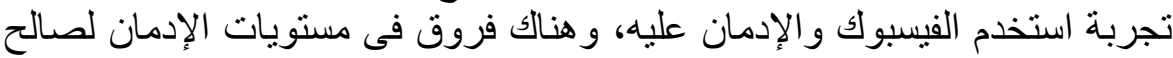

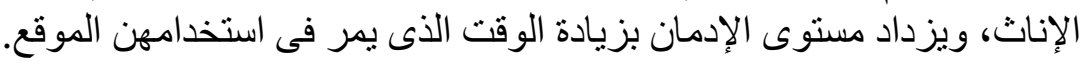

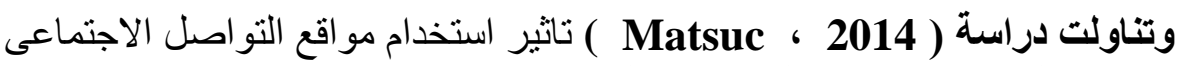

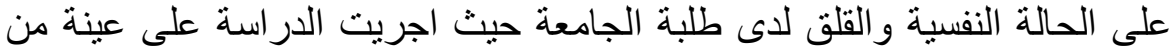
الطلبة قو امها 190 طالب وطالبة من جامعة صربيا ، وطبة ولنق عليها مقياس استخدام 
مو اقع التو اصل الاجتماعى ومقياس الحالة النفسية ، و اسفرت النتائج عن وجود تأثير

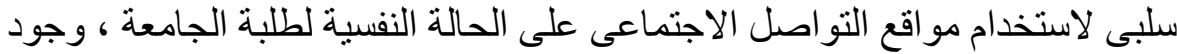

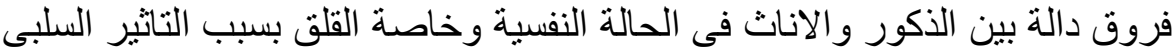

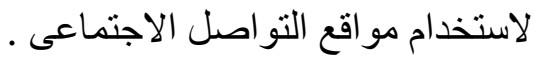

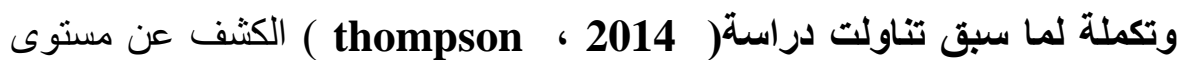

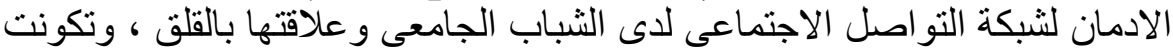

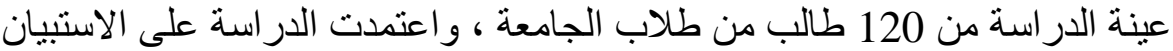

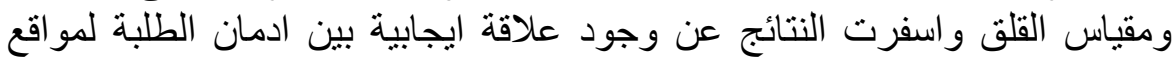

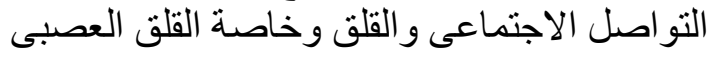
التعليق على الاراسات السابقة وحدود الاستفادة منها:-

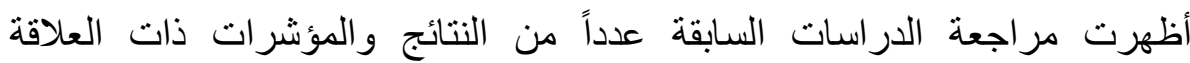

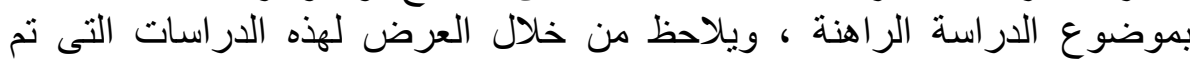

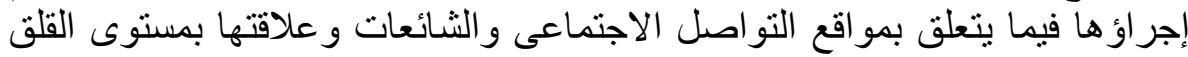

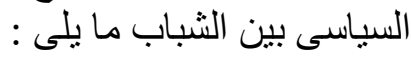

1- وجود العديد من الدراسات العربية والأجنبية التى تتناول موضوع التهات الثبكات الاجتماعية سواء فيما يتعلق بالثائعات والتأثثرات التية السياسية مما يثرى الخلفية

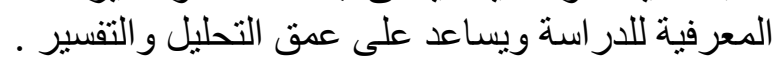

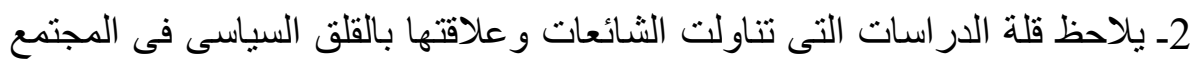

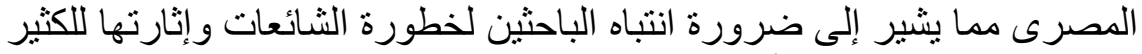

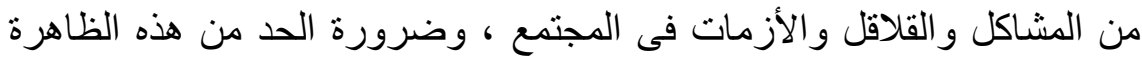

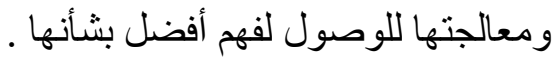

3- توصلت الدراسات سواء العربية أو الأجنبية إلى وجود دور مباشر لوسائل الإعلام

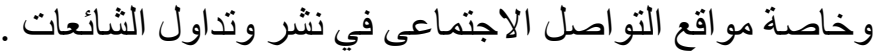

4ـ أكدت أغلب الدر اسات على الدور الكبير لوسائل الاتصال الحديثة كاحد مصادر

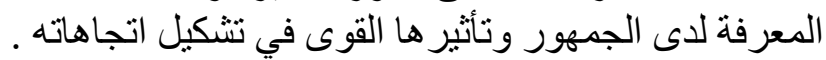

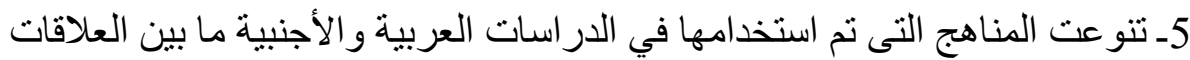

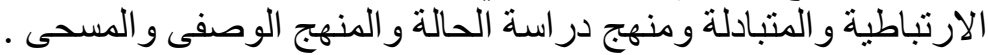

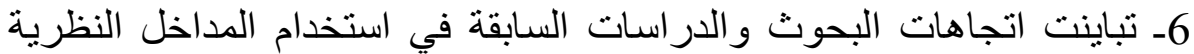

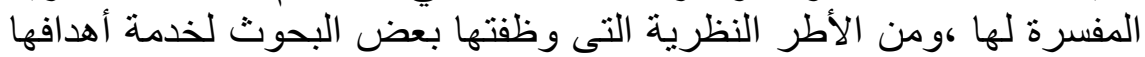

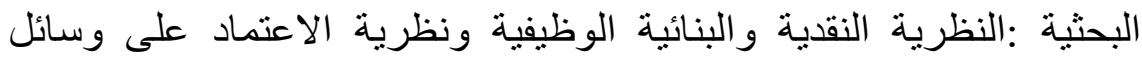

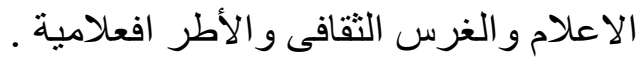




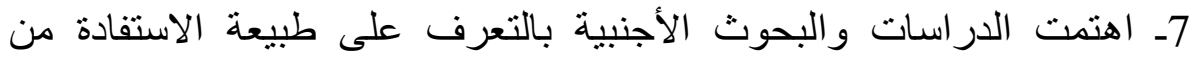

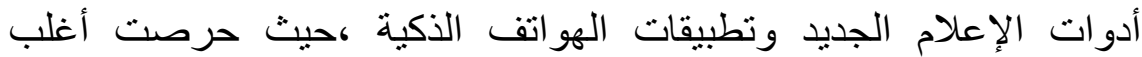
الدراسات على رصد مظاهر الاستفادة من التكنولوجيا في الأداء الإعلامى الفى الفات

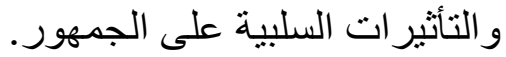

8ـ اعتمدت أغلب الدراسات على أداة الاستبيان والمقابلة وتحليل المضمون ،بينما

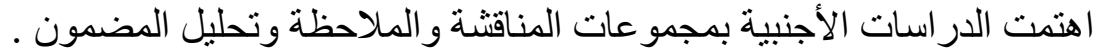
أوجه الاستفادة من الدراسـات السابقة :

1- جاءت الدراسات العربية والأجنية ثرية من حيث الأهداف والأهمية والمنهج

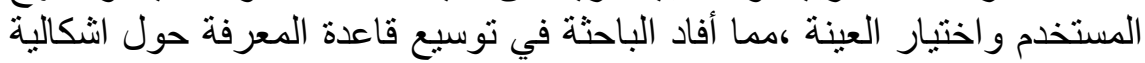

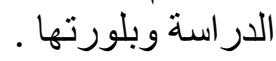

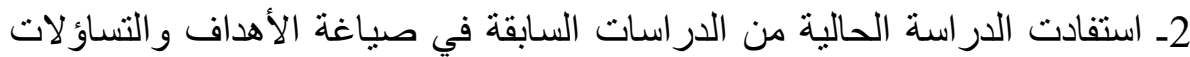

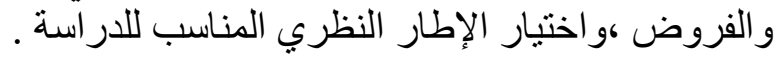

$$
\text { الإطار النظرى للاراسة : }
$$

أولاً : نظرية انتقال الشائعات Rumor Transmission Theory

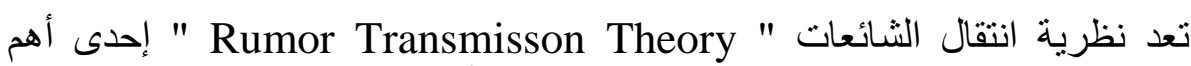
النظريات التى تفسر حركة انتقال الثائعات بين الأفر اد وكيفية استقبالهم لها ، التهات حيث اعتمد تايلور باكنر (1995) Taylor Buckner على مفهوم "القدرات التفات النقدية Critical Ability

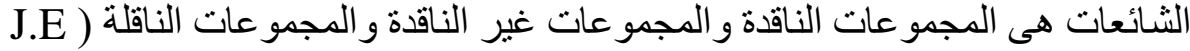

. (Roeckelein ,2006

واعتمد باكنر في بناء نظريته على الأساس النظرى الذى وضعه كور اس Chorus

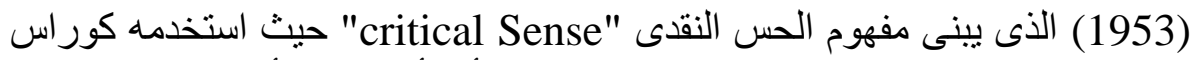

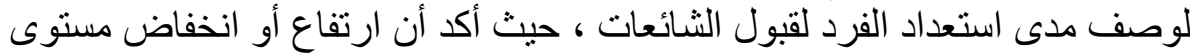

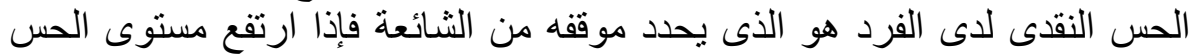

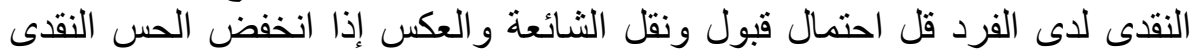

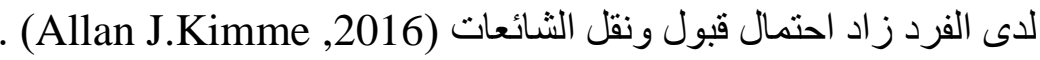
واستخدم التفكير الناقد كمتغير أساسى فى العديد من الدراسات التى تتناول المعلومات

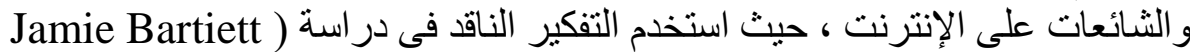
و \& Cart Miller , (2011 والتى هدفت إلى التعرف الأنى على مستوى إجادة الأطفال

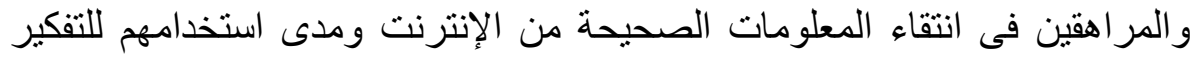

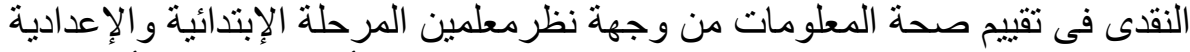
، من خلال تطبيق الاستبيان على الإنترنت ل506 معلم ، و أظهرت النتائج أن 47 الإعة 


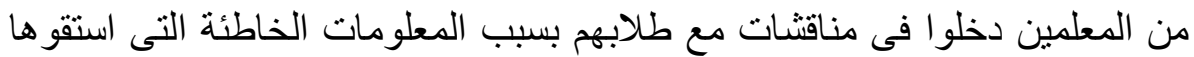

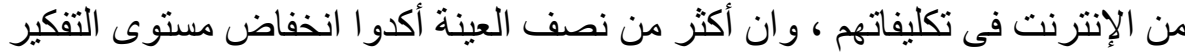

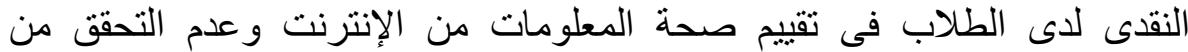

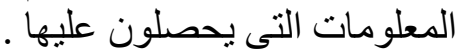

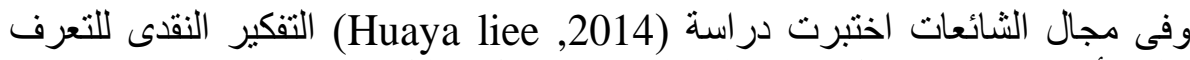
على تأثيره فى عملية نقل ونشر الثنائعات من خلال تحليل التغريدات على موقع تويتر

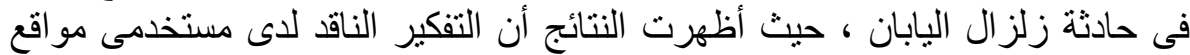

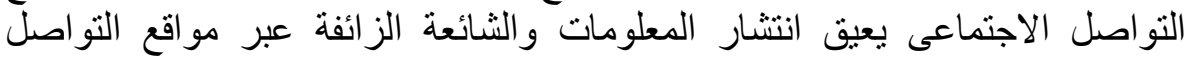

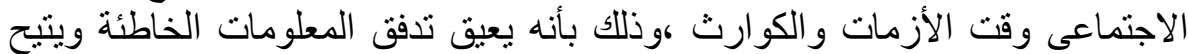

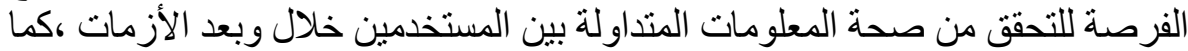
أظهرت نتائج التحليل أن أغلبية المستخدمين كتبو ا تعليقات وتغريدات التينة تناولت نقات نقات و أسئلة

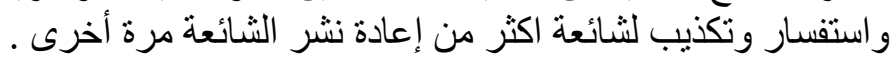

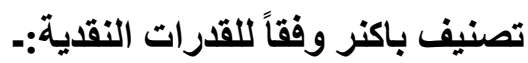

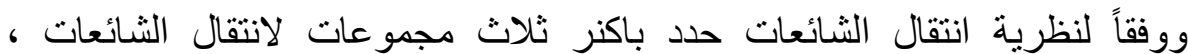

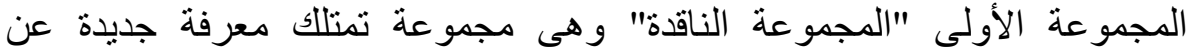

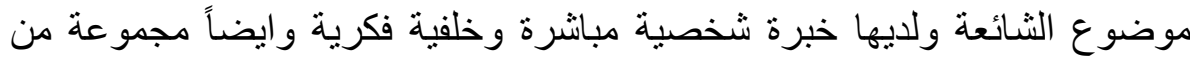

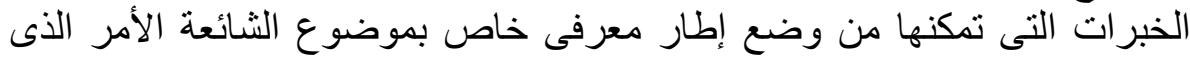

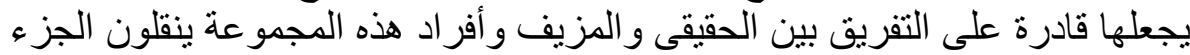

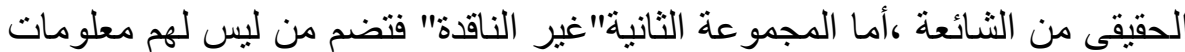

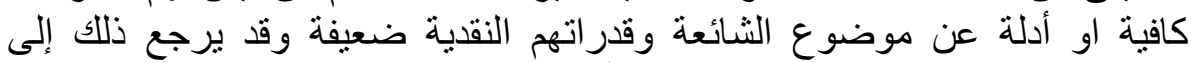

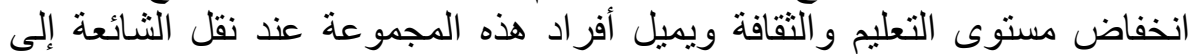

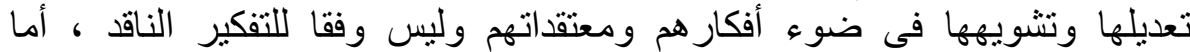

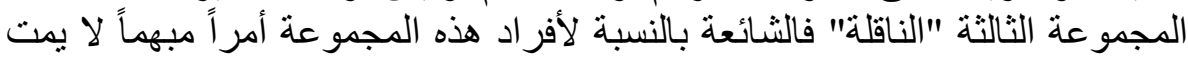

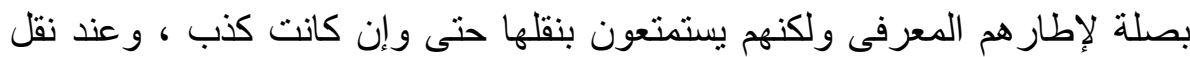

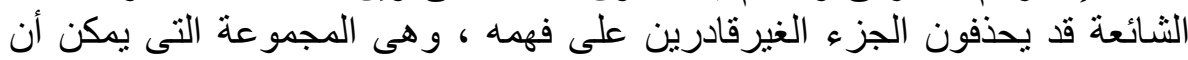

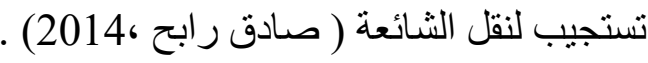
فى ضوء ما سبق يتضح أن النظرية تفترض وجود علاقة بين الإطار المعرفى الني

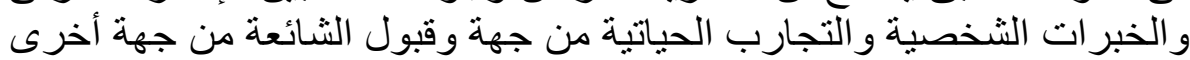
، فالأشخاص الذين يمتلكون معرفة كافية عن موضوع الثانية الثائعات وخبرة شخصية مباشرة مرتبطة بموضوع الشائعة فهم قادرون على التفريق بين التين

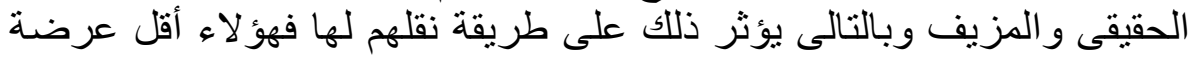

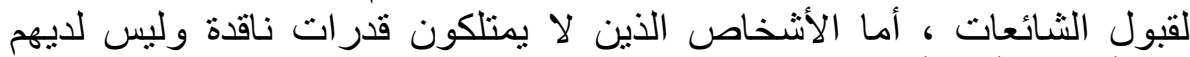

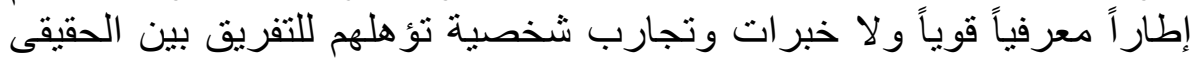
و المزيف فهم الأكثر عرضار لانة لقبول الثائعة . 


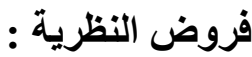

وتفترض النظرية وجود علاقة عكسية بين ارتفاع المستوى المعرفى والخبرات

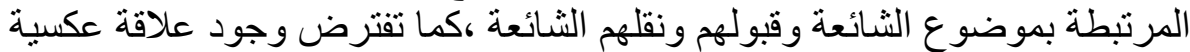

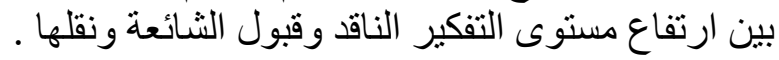

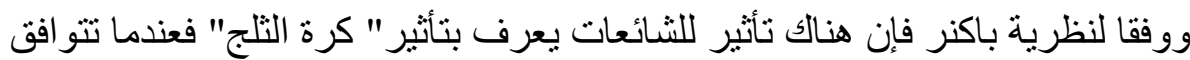

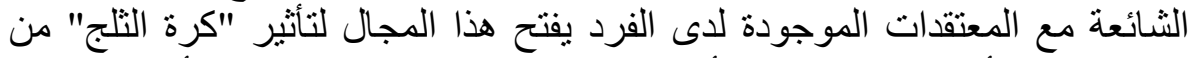

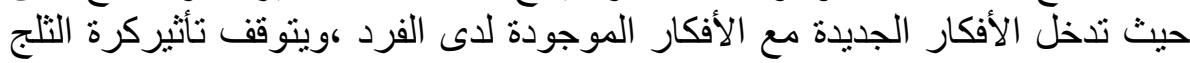

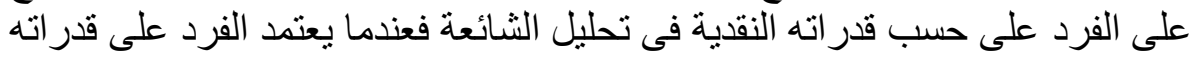

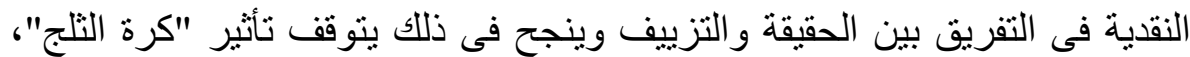

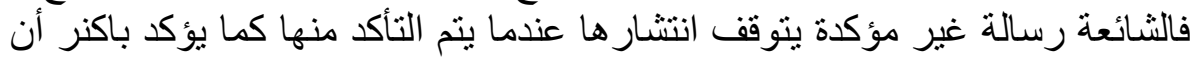

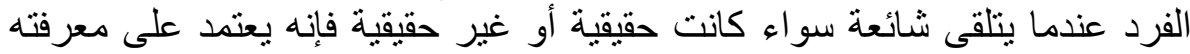

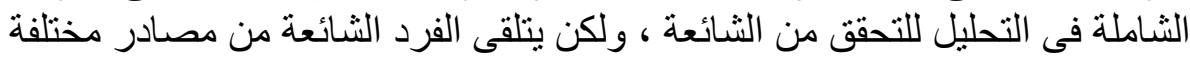

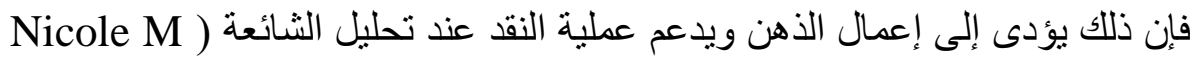
. Robinson, 2008

و أضاف تايلور باكنر أن هناك علاقة بين الطريقة التى تنقل بها الثائعات وتأثير ذلك

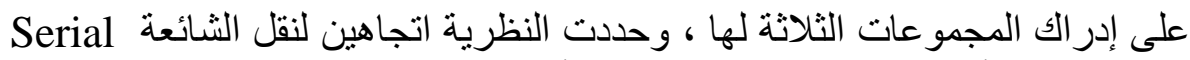
Chain

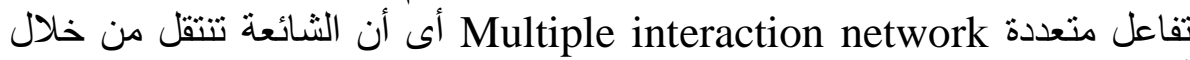
أكثر من مصدر وهذا الاتجاه يجعل التحقق من الثنائعات والتنقريق بين المزيف والحقيقى أكثر صعوبة (2007, Mark Schinlert) وتفترض النظرية وجود علاقة بين طريقة نقل الثنائعات وقبول الثائعة ، فالثائعة

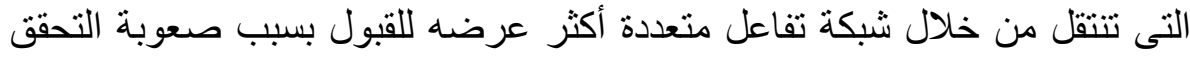

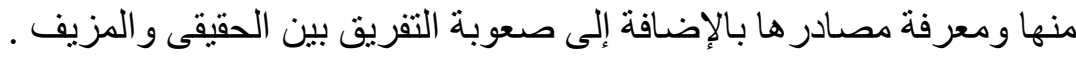

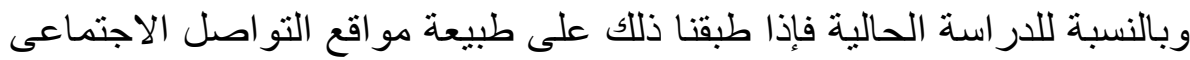

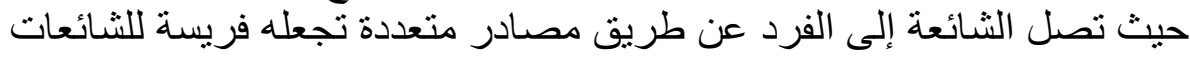

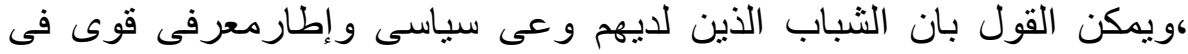

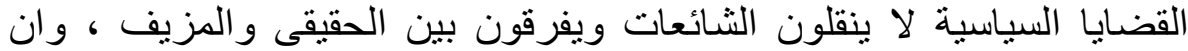

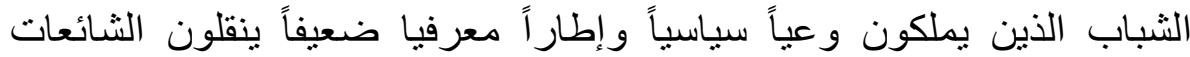

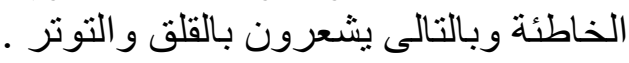

ثانياً : نظرية الانفعال المعرفى Congnitive Emotion Theory

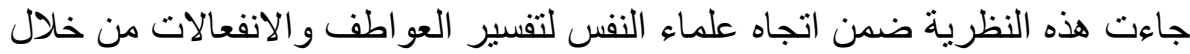

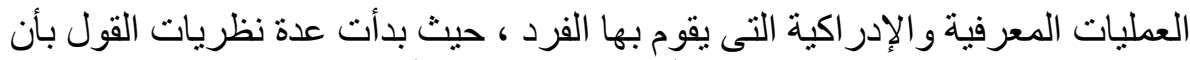
النشاط المعرفى فى شكل معرفة وأحكام وتقييمات وأفكار مسبب رلئ رئيسى لحدوث 


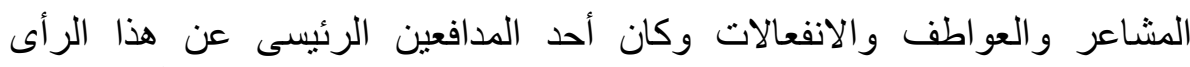

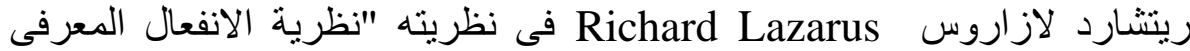

. (Reisenzen .R. ,2009)"

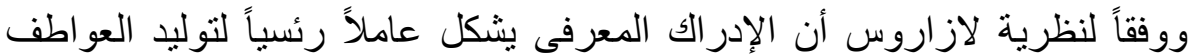

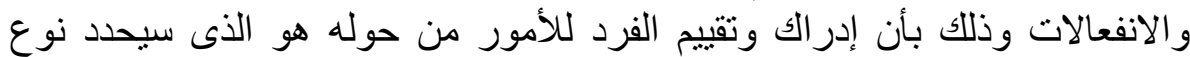

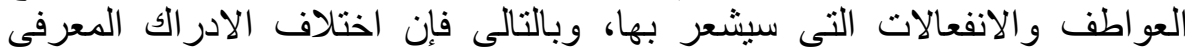

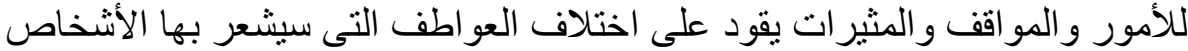
إزاء نفس الموقف وأن هذا الاختلاف سيؤدى بدوره إلى إلى اختلاف فى السلوك الذى الذى

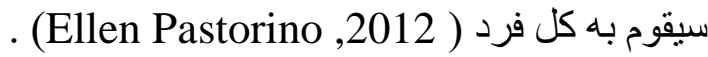

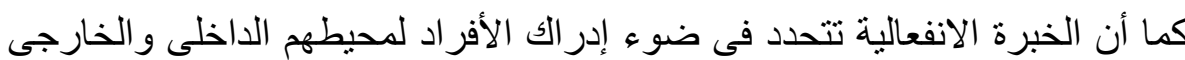

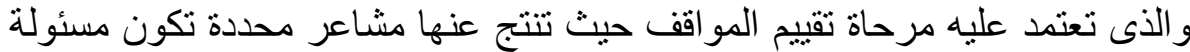

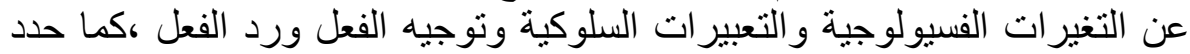

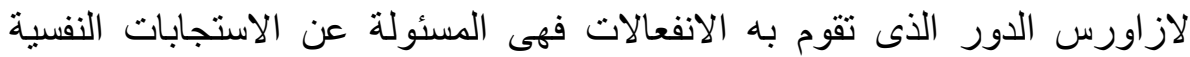

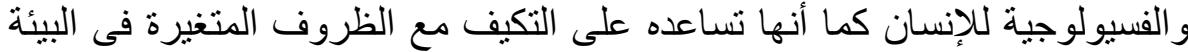

. (Becky Lynn Omdahi ,2014)

$$
\text { متغيرات النظرية :- }
$$

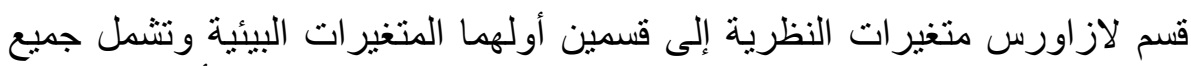

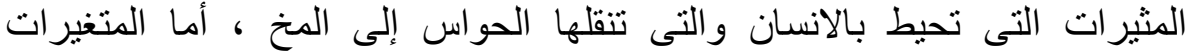

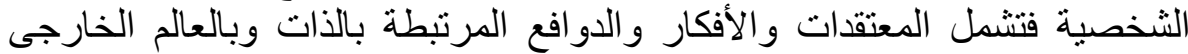

. (Lazarus Richaid ,2013)

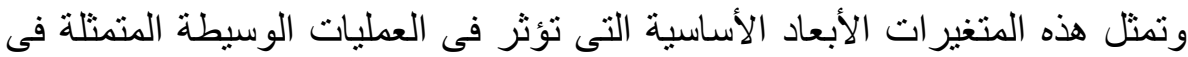

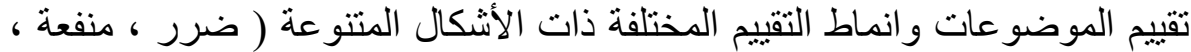

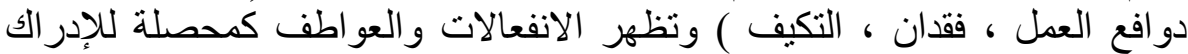

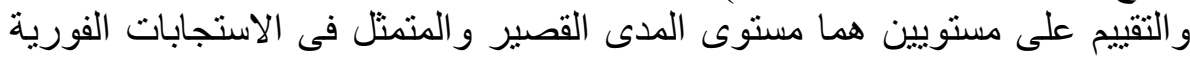

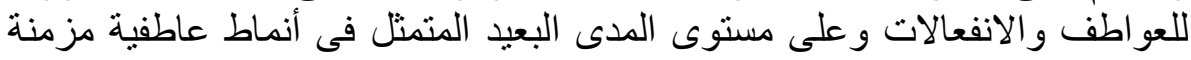

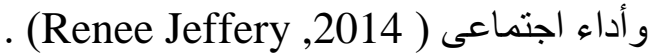

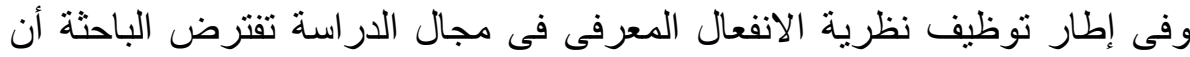

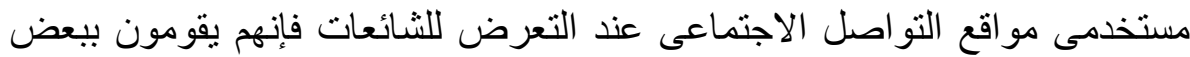

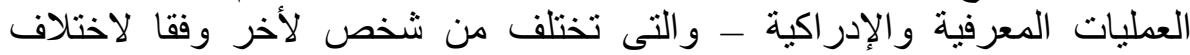

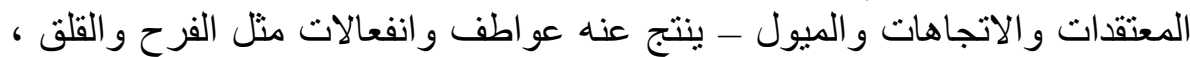

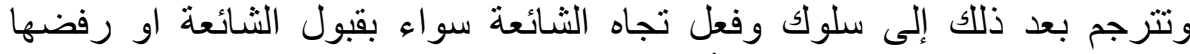

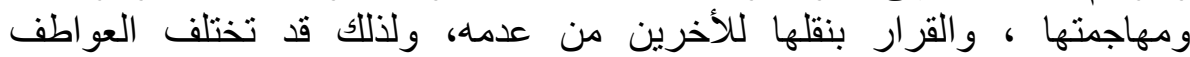
و الانفعالات و السلوكيات تجاه الثنائعة الواحدة . 


$$
\text { تساؤلات الاراسة :- ت ت }
$$

تسعى الدراسة إلى طرح عدد من التساؤلات التى تقيس الإجابة عليها أبعاد الدور

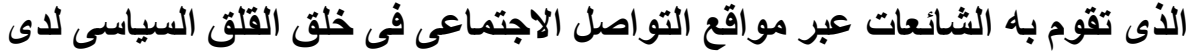

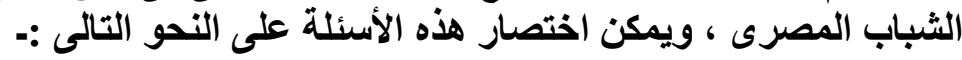

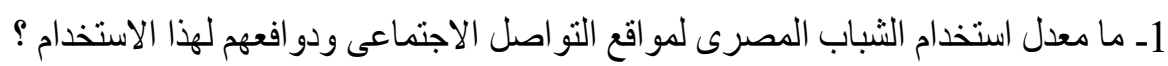

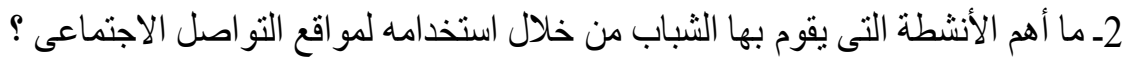

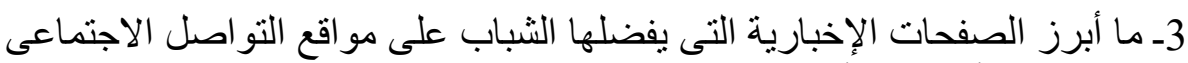

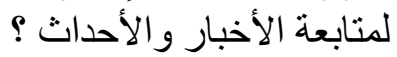

4ـ ما أهم أر اء المستخدمين لمواقع التو اصل الاجتماعى من حيث مصداقيتها وسر عة

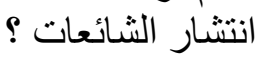

5ـ ما مقدار الثقة فى الأخبار و المعلومات التى تتشر عبر مواقع التو اصل الاجتماعى التصى و علاقتها بمستوى القلق السياسى لدى الثباب الثمات المصرى ؟

6ـ ما أهداف الثائعات التى تتشر عبر مو اقع التو اصل الاجتماعى وأثنار ها فى المجتمع ؟ 7ـ ما أهم أوقات بروز الثائعات التى تنشر عبر مو اقع التو اصل الاجتماعى و علاقتها

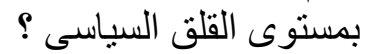
8ـ ما المعوقات التنظيمية والثخصية التى تساعد على انتشار الثنائعات عبر مواقع

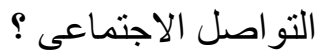

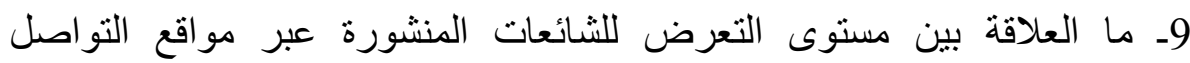

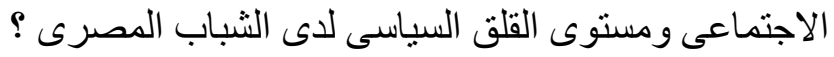

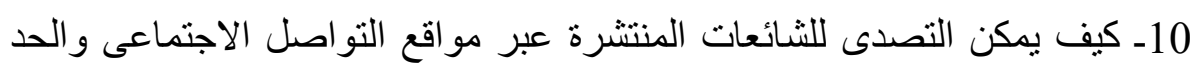
من القلق السياسى بين الثباب ؟ النعات

$$
\text { فروض الدراسة :- من الفقئ }
$$

فى ضوء تحديد المشكلة البحثية وأهدافها و إطار ها النظرى تتحدد فروض الدراسة

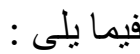
الفرض الأول : توجد فروق دالة إحصائياً بين الثباب المصرى فى كثافة وعادات

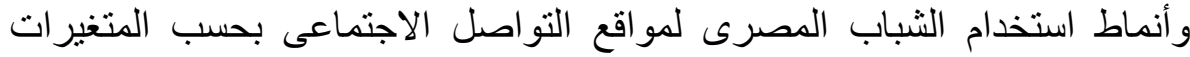

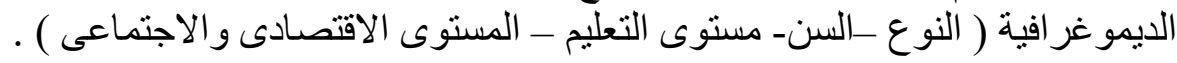

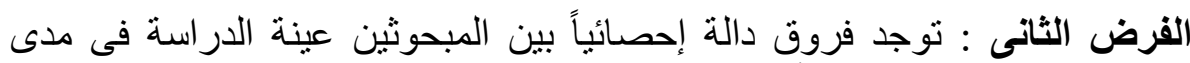

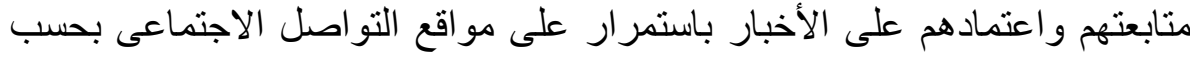

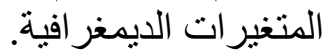




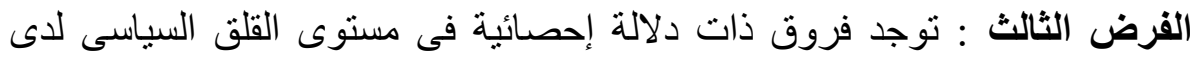

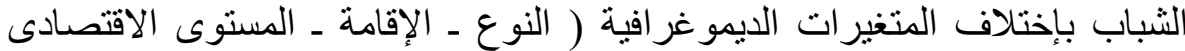

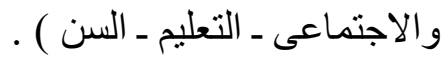

الفرض الرابع : توجد فروق ذات دلالة إحصائية بين كثافة تعرض الثباب لمو اقع التواصل

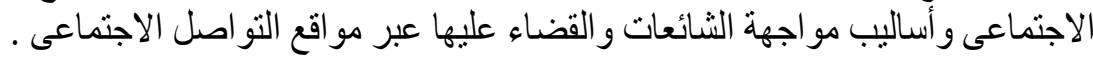

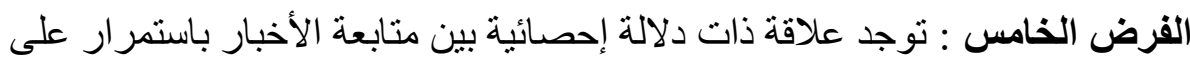

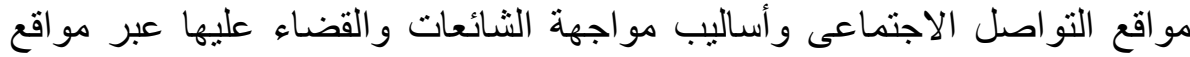

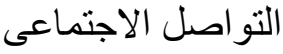

\section{الإجراءات المنهجية للاراسة}

نوع الاراسة :-

اعتمدت الباحثة على الدراسات الوصفية Dscriptive study و التى تهدف إلى التى تصنيف البيانات و الحقائق التى يتم تجمعيها وتسجيلها ثم تفسير ها وتحليل هذه البيات البيانات

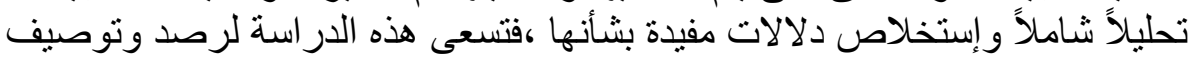

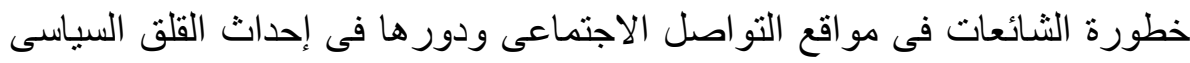

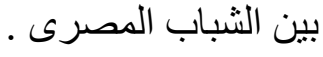

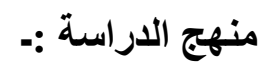

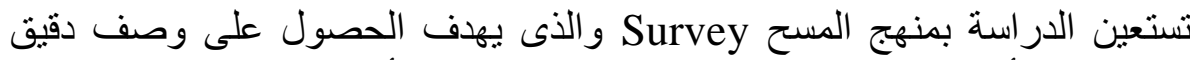

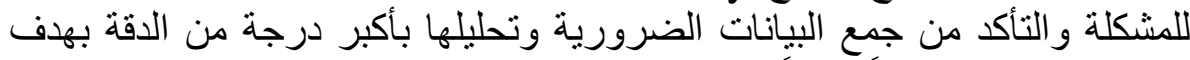

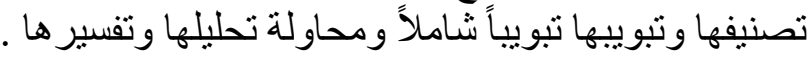

$$
\text { مجتمع الاراسة :- }
$$

اعتمدت الباحثة على العينة العمدية فى دراسة الحمهور و التى تعتمد على قيام الباحثة

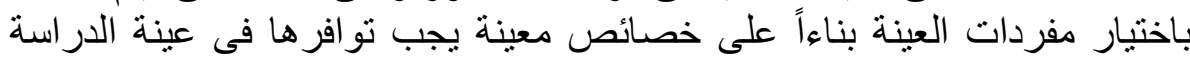

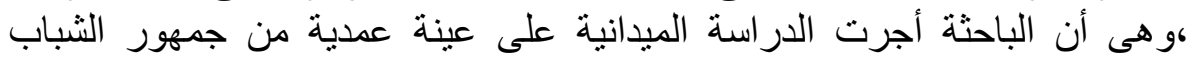

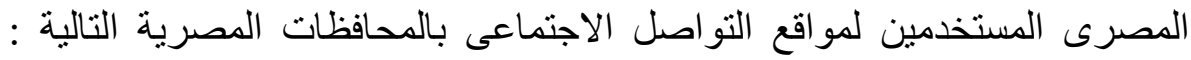

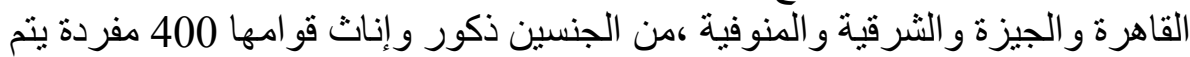

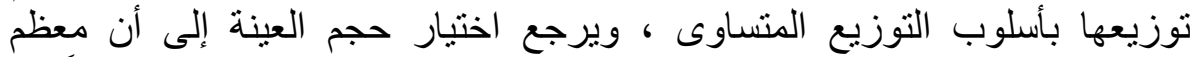

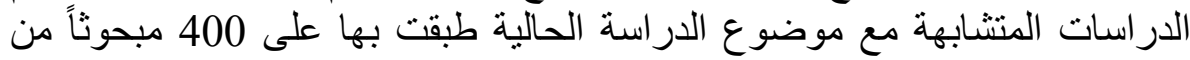

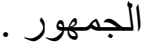

مبررات اختيار الشباب المصرى كعينة للاراسة الميدانية الحالية: ـ

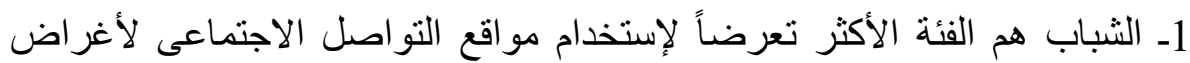

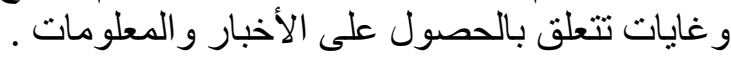


2ـ أنه مجتمع له أهميته الخاصة فهذه الفئة العمرية أكثر الثر ائح الاجتماعية استخداماً

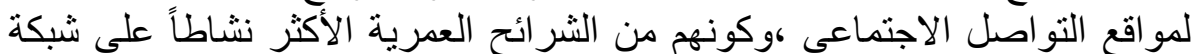

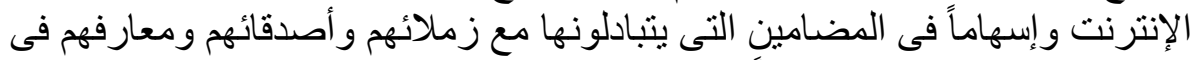

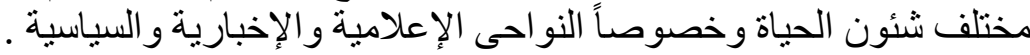

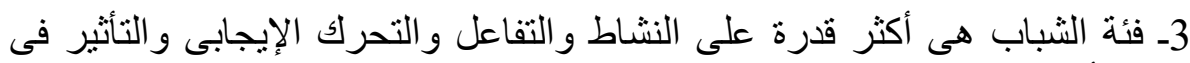
كافة الأمور وخاصة السياسية.

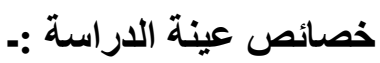

تم اختيار عينة الدر اسة من أربع محافظات هى : القاهرة و الجيزة و الثرقية و المنوفية

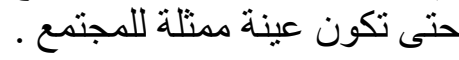

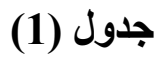

يوضح وصف عينة الدراسة

\begin{tabular}{|c|c|c|c|}
\hline \multicolumn{2}{|c|}{ إجمالي } & \multirow{2}{*}{\multicolumn{2}{|c|}{ المتغير ات }} \\
\hline$\%$ & ك & & \\
\hline 25 & 100 & 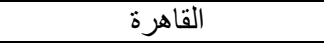 & \multirow{5}{*}{ المحافظة } \\
\hline 25 & 100 & الجيزة الجيزة & \\
\hline 25 & 100 & الثرقية الثرا & \\
\hline 25 & 100 & 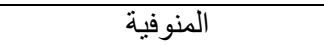 & \\
\hline 100 & 400 & 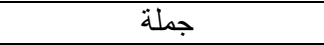 & \\
\hline 50 & 200 & ذكور & \multirow{3}{*}{ النوع } \\
\hline 50 & 200 & إناث & \\
\hline 100 & 400 & جملة & \\
\hline 29.8 & 119 & من 18 إلى أقل من 25 عام & \multirow{4}{*}{ 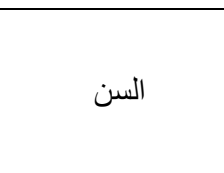 } \\
\hline 43.5 & 174 & من 25 إلى أقل من 30 عام & \\
\hline 26.8 & 107 & أكبر من 30 عام & \\
\hline 100 & 400 & جملة & \\
\hline 52.5 & 210 & ريف & \multirow{3}{*}{ الإقامة } \\
\hline 47.5 & 190 & 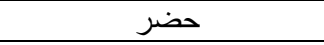 & \\
\hline 100 & 400 & جملة جما جما & \\
\hline 24 & 96 & منخفض & \multirow{4}{*}{ لمستوى الاقتصادى } \\
\hline 54.5 & 218 & متوسط & \\
\hline 21.5 & 86 & مرتفع & \\
\hline 100 & 400 & 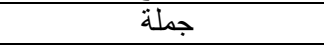 & \\
\hline 22 & 88 & دون المتوسط & \multirow{5}{*}{ المستوى التعليمي } \\
\hline 26.8 & 107 & متوسط & \\
\hline 46.3 & 185 & جامعي & \\
\hline 5 & 20 & در اسات عليا & \\
\hline 100 & 400 & جملة & \\
\hline
\end{tabular}


من حيث المحافظة: نسبة 25\% من أفر اد العينة بححافظة القاهرة, ونسبة 25\% منهم بحمافظة

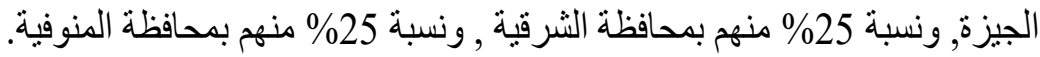

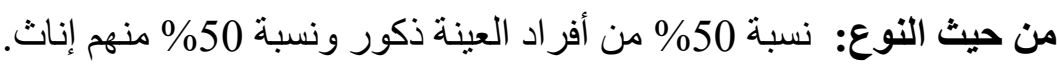

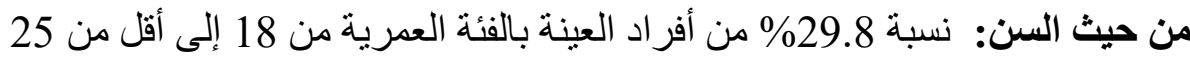

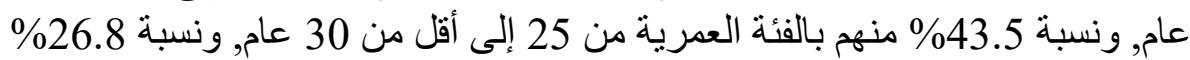
منهم بالفئة العمرية أكبر من 30 عام. من حيث الإقامة: نسبة 52.5\% من أفراد العينة مقيمين بالريف, ونسبة 47.5 \%

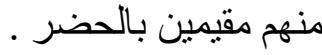

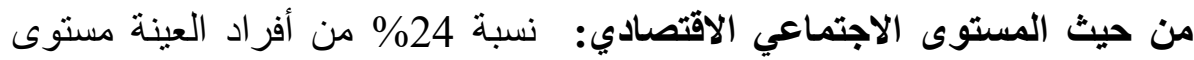

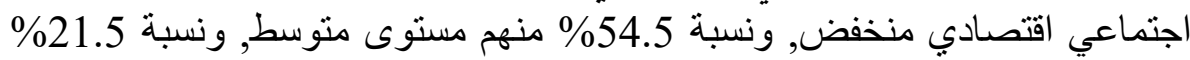
منهم مستوى مرتفع.

من حيث المستوى التعليمي: نسبة 22\% من أفراد العينة مستوى تعليمي دون

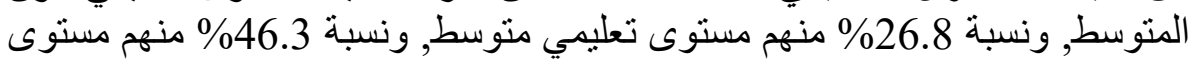
تعليم جامعي, ونسبة 5\% منهم مستوى تعليم در اسات عليا.

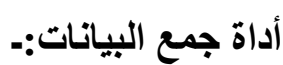

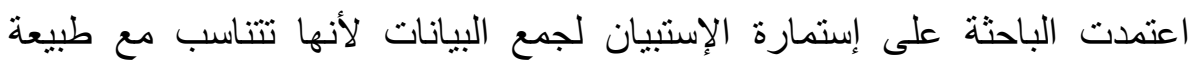

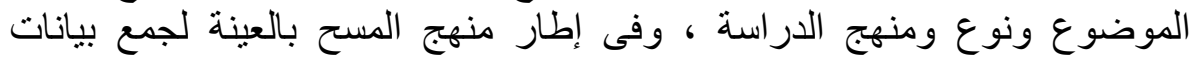

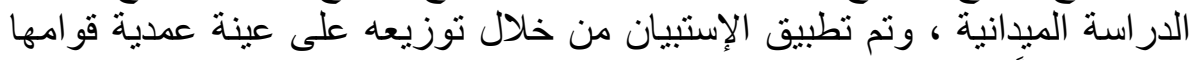

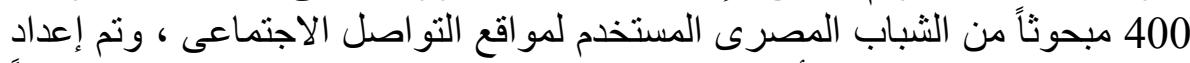

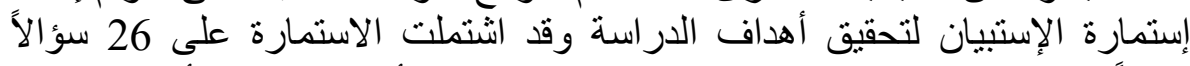

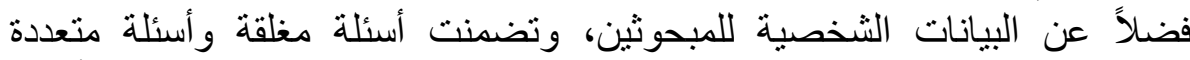

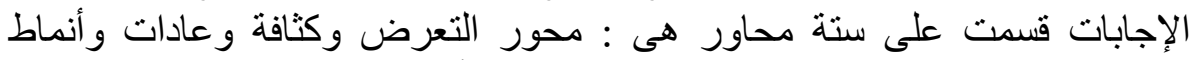

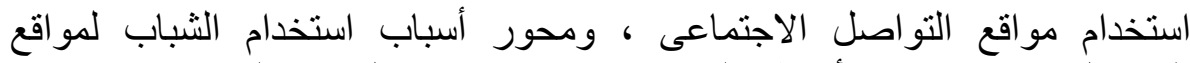

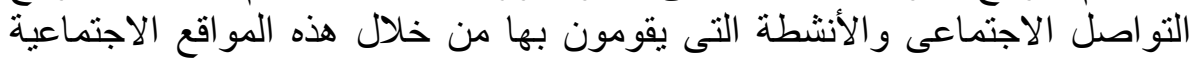

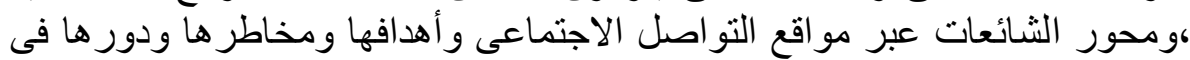

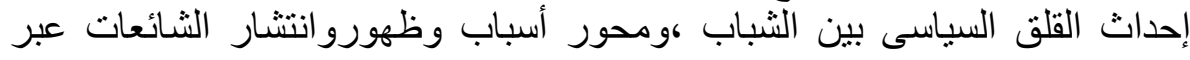

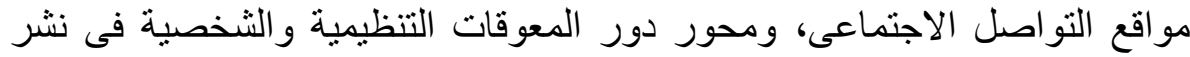

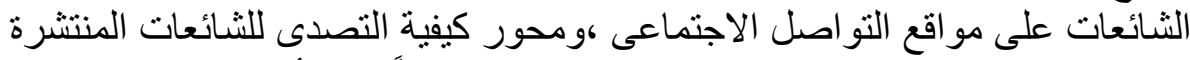

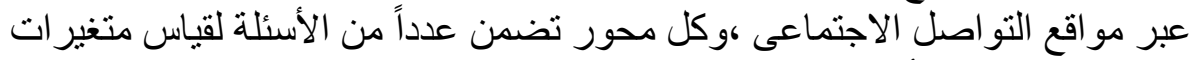

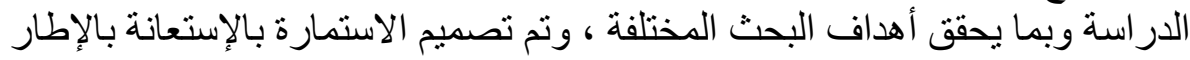

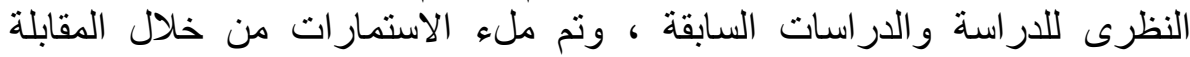
المباثرة مع عينة الدراسة خلال شهر أكتوبر 2019م . 
إجراءات الصدق والقياس :

تم قياس الصدق الظاهرى Face validity من خلال :1ـ تصميم الاستمارة فى ضوء أهداف وتساؤ لات الدر اسة .

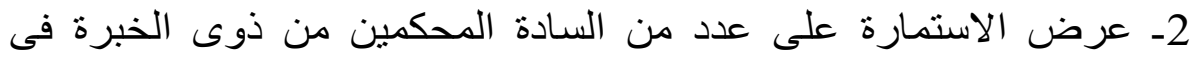

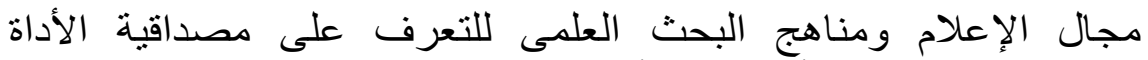

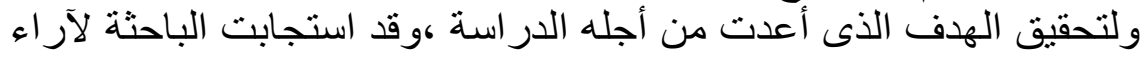

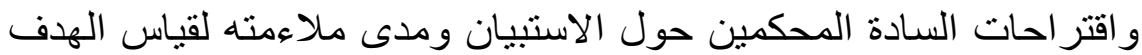

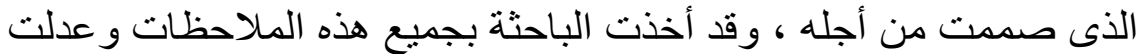

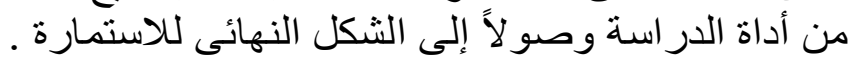

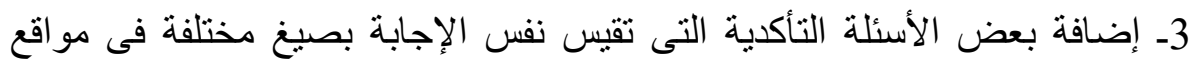

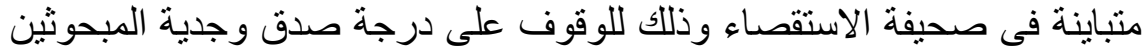
فى إجاباتهم على الأسئلة .

\section{تم قياس الثبات Reliability من خلال : -}

يهدف الثبات إلى التأكيد من وجود درجة كبيرة من الإتساق بين المبحوثين عند تطبيق

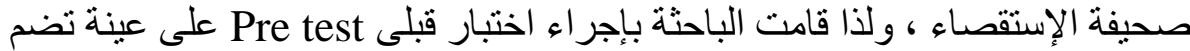

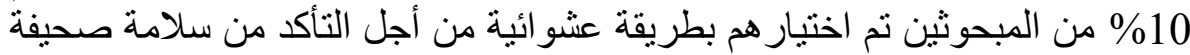

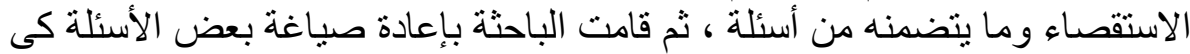

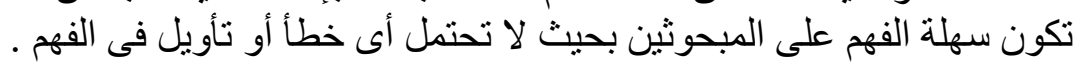

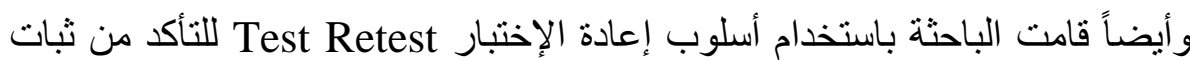

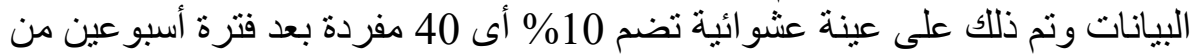

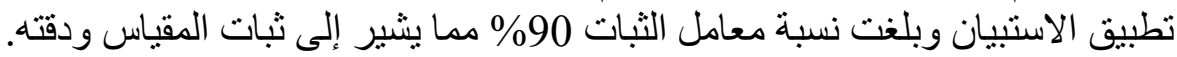

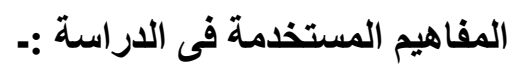

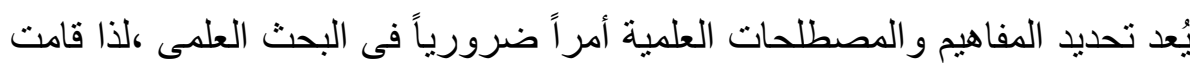
الباحثة بتحديد عدد من المفاهيم المستخدمة فى الدر اسة كما يلى :-

الثائعات : هى كل خبر أو معلومة أوبيان أو صورة او فيديو أو معلومات نصية أو غبر نصبة

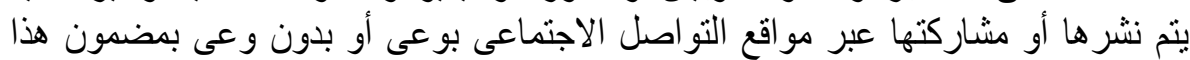

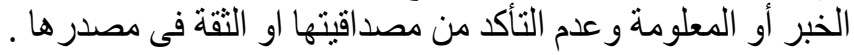

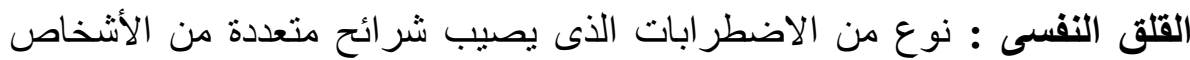

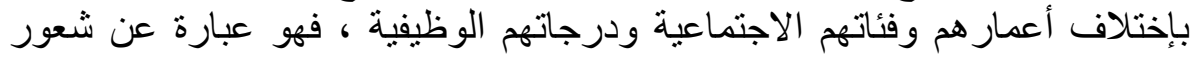
بالقلق مبالغ فيه. 


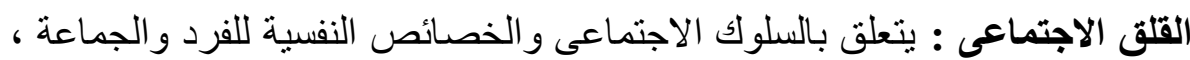

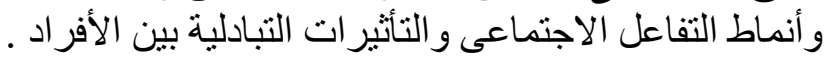

القلق الفسيولوجى : يتعلق بالتأثيرات النفسية المرتبطة بالثخصية ، وربطها مع العي الظواهر الحيوية والفسيولوجية الخاصة بالجهاز العصبى مثل طبيعة السلوك وكيفية بالكية

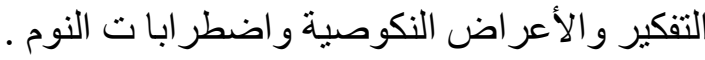
المعالجة الإحصائية للبيانات:

بعد الانتهاء من جمع بيانات الدر اسة الميدانية، تم ترميز البيانات و إدخالها إلي الحاسب الآلي، ثنم معالجتها وتحليلها واستخراج التانية النتائج الإحصائية " SPSS باستخدام برنامج " الحزمة الإحصائية للعلوم الاجتماعية والخية Statistical Package for the Social Science المعاملات و الاختبار ات الإحصائية التالية في تحليل بيانات الدر اسة: ـالتكر ار ات البسيطة والنسب المئوية. ـالمتوسطات الحسابية والانحر افات المعيارية. ـمعامل ارتباط بيرسون للعلاقة الخطية بين متغيرين. ـاختبار كا2 (Chi Square Test ) لدر اسـة الدلالة الإحصائية للعلاقة بين متغيرين من المتغير ات الاسمية ( Nominal )

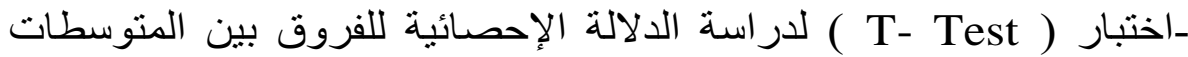

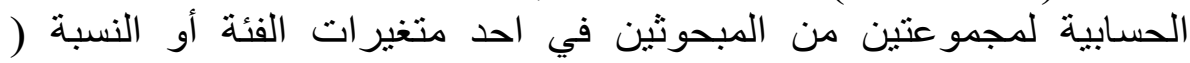

( Interval Or Ratio

ـ تحليل التباين ذي البعد الواحد (One Analysis of Variance ) المعروف اختصسار ا باسم ANOVA لدر اسة الدلالة الإحصائية للفروق بين

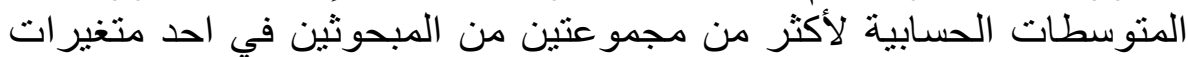
الفئة أو النسبة ( Interval Or Ratio)

ـالاختبار ات البعدية ( Post Hoc Tests ) بطريقة اقل فرق معنوي ( ( Least Significance Difference

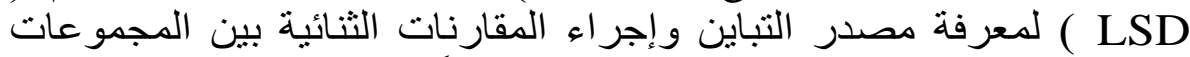
التي يثبت ANOVA وجود فروق دالة إحصائياً بينها. نتائج الدراسة :

تعرض الباحثة لنتائج الدر اسة الميدانية من خلال عرض النتائج العامة للار اسة وفقا

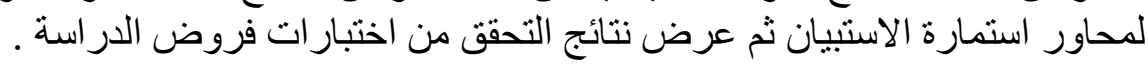


أولاً : النتائج العامة للاراسة :

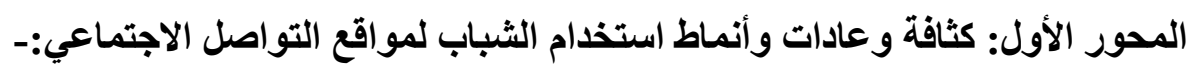
1- ترتيب أهم مواقع التواصل الاجتماعي التي يستخدمها الثباب المصري:

جدول (2)

يوضح ترتيب أهم مواقع التو اصل الاجتماعي التي يستخدمها الثباب المصري

\begin{tabular}{|c|c|c|c|c|c|c|c|c|c|c|c|}
\hline \multirow[t]{2}{*}{ الترتيب } & \multirow[t]{2}{*}{ منوسط } & \multicolumn{8}{|c|}{ الترتيب ن=400 } & \multirow{2}{*}{\multicolumn{2}{|c|}{ الموقع }} \\
\hline & & 8 & 7 & 6 & 5 & 4 & 3 & 2 & 1 & & \\
\hline \multirow[t]{2}{*}{1} & \multirow[t]{2}{*}{6.60} & 38 & 5 & 5 & 2 & 1 & 67 & 94 & 188 & 5 & \multirow[t]{2}{*}{ face book } \\
\hline & & 9.5 & 1.3 & 1.3 & 0.5 & 0.3 & 16.8 & 23.5 & 47 & $\%$ & \\
\hline \multirow[t]{2}{*}{2} & \multirow[t]{2}{*}{6.07} & 6 & 38 & 5 & 5 & 73 & 27 & 184 & 62 & 5 & \multirow[t]{2}{*}{ Twitter } \\
\hline & & 1.5 & 9.5 & 1.3 & 1.3 & 18.3 & 6.8 & 46 & 15.5 & $\%$ & \\
\hline \multirow[t]{2}{*}{6} & \multirow[t]{2}{*}{3.98} & 97 & 5 & 66 & 67 & 33 & 99 & 2 & 31 & 5 & \multirow[t]{2}{*}{ YouTube } \\
\hline & & 24.3 & 1.3 & 16.5 & 16.8 & 8.3 & 24.8 & 0.5 & 7.8 & $\%$ & \\
\hline \multirow[t]{2}{*}{5} & \multirow[t]{2}{*}{4.01} & 26 & 116 & 35 & 42 & 92 & 46 & 9 & 34 & ك & \multirow[t]{2}{*}{ Linked in } \\
\hline & & 6.5 & 29 & 8.8 & 10.5 & 23 & 11.5 & 2.3 & 8.5 & $\%$ & \\
\hline \multirow[t]{2}{*}{7} & \multirow[t]{2}{*}{3.59} & 27 & 100 & 62 & 129 & 37 & 2 & 33 & 10 & 5 & \multirow[t]{2}{*}{ Whats app } \\
\hline & & 6.8 & 25 & 15.5 & 32.3 & 9.3 & 0.5 & 8.3 & 2.5 & $\%$ & \\
\hline \multirow[t]{2}{*}{8} & \multirow[t]{2}{*}{3.17} & 106 & 4 & 126 & 89 & 36 & 37 & 0 & 2 & 5 & \multirow[t]{2}{*}{ Googlet } \\
\hline & & 26.5 & 1 & 31.5 & 22.3 & 9 & 9.3 & 0 & 0.5 & $\%$ & \\
\hline \multirow[t]{2}{*}{3} & \multirow[t]{2}{*}{4.35} & 6 & 121 & 9 & 66 & 96 & 29 & 38 & 35 & 5 & \multirow[t]{2}{*}{ Instagram } \\
\hline & & 1.5 & 30.3 & 2.3 & 16.5 & 24 & 7.3 & 9.5 & 8.8 & $\%$ & \\
\hline \multirow[t]{2}{*}{4} & \multirow[t]{2}{*}{4.24} & 94 & 11 & 92 & 0 & 32 & 93 & 40 & 38 & ك & \multirow[t]{2}{*}{ Snap chat } \\
\hline & & 23.5 & 2.8 & 23 & 0 & 8 & 23.3 & 10 & 9.5 & $\%$ & \\
\hline
\end{tabular}

يتضح من الجدول السابق أن ترتيب مواقع التواصل الاجتماعي التي يستخدمها

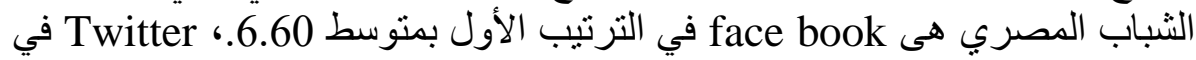

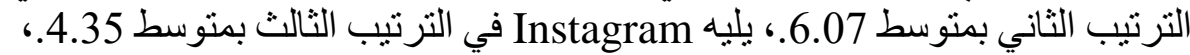

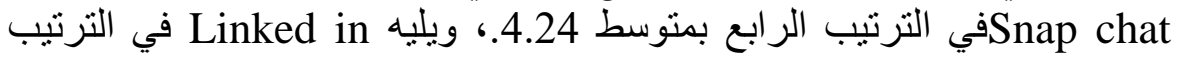

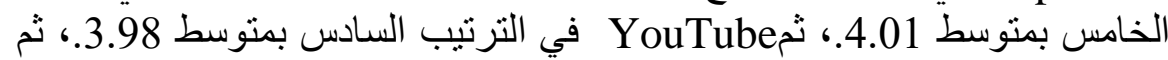
Whats app

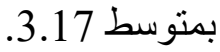

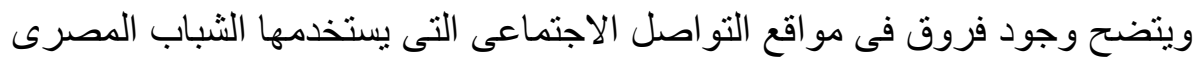

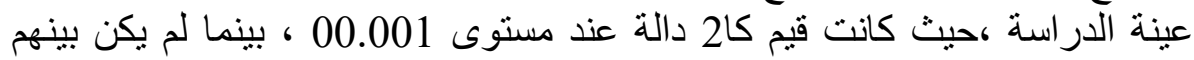

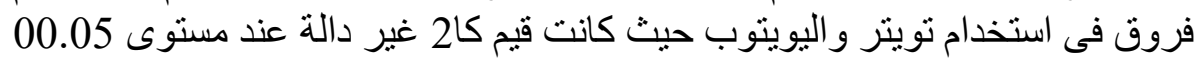

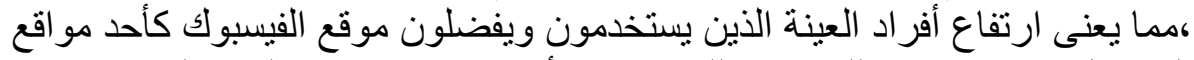

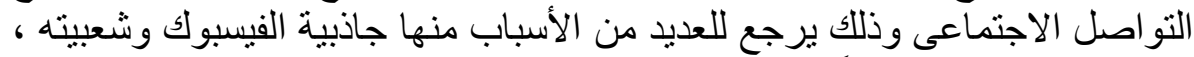

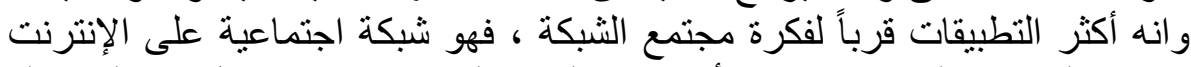

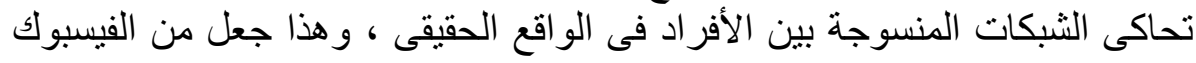


الثبكة الإجتماعية الأولى والأكثر تفضيلاً واستخداماً لاى الثباب عينة الدراسة ، واستة

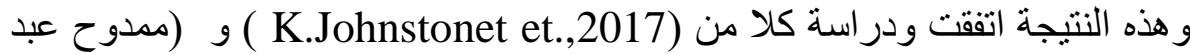

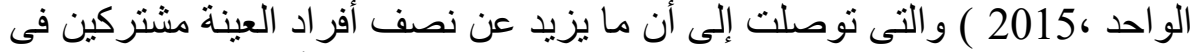

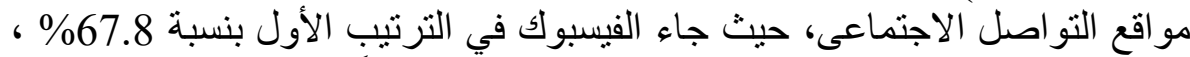

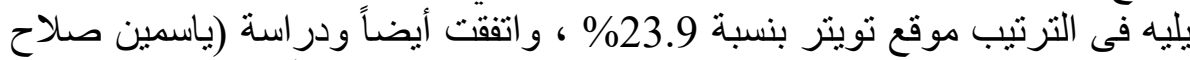

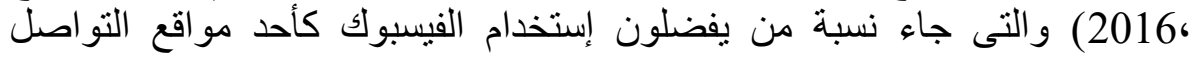

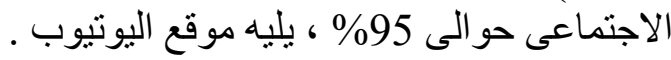

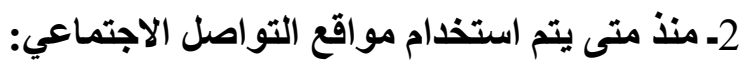
جدول (3) يوضتح منذ متى يتم استخدام مواقع التواصل الاجتماعي

\begin{tabular}{|c|c|c|c|c|}
\hline \multirow{2}{*}{ مستوى المعنوية } & \multirow{2}{*}{25} & \multicolumn{2}{|c|}{ الإجمالي } & \multirow{2}{*}{ منذ متى يتم استخدام مواقع التواصل الاجتماعي } \\
\hline & & $\%$ & 5 & \\
\hline \multirow{4}{*}{0.001} & \multirow{4}{*}{211.685} & 2.5 & 10 & منذ أقل من سنة \\
\hline & & 35.8 & 143 & من عام إلى أقل من 3 أعو ام \\
\hline & & 61.8 & 247 & من 3 أعوام فأكثر \\
\hline & & 100 & 400 & الإجمالى \\
\hline
\end{tabular}

يتضح من الجدول السابق أن نسبة 61.7\% من أفر اد العينة بيتخدموا مو اقع التو اصل

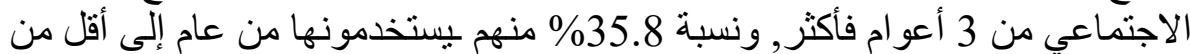
3 أعو اح, ونسبة 2.5\% منهم يستخدمونها منذ أقل من سنة.

كذللك يتضح وجود فروق ذات دلالة إحصائية بين أفراد العينة في منذ متى يتم

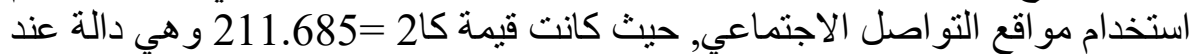
مستوى دلالة 0.001, ارتفاع نسبة أفراد العينة الذين يستخدموا مواقع التواصل التصل

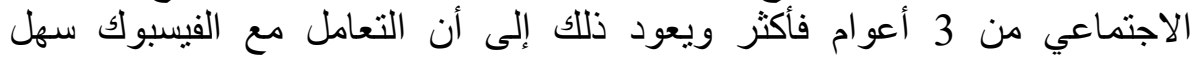

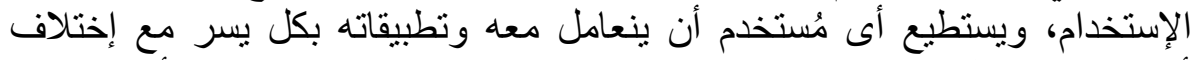

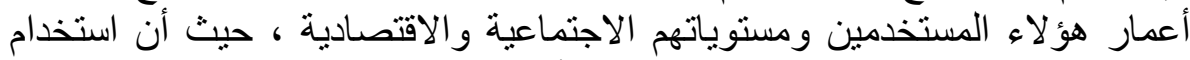

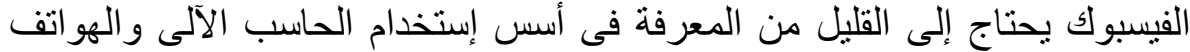
الأكية من أجل النشر وتحقيق التول اصل التل عبر الإنترنت .

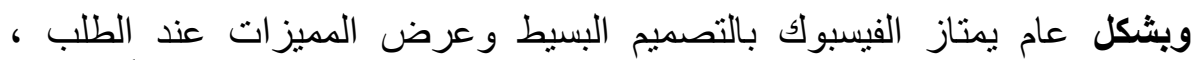

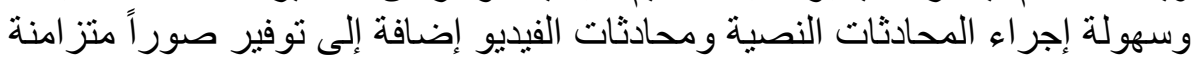

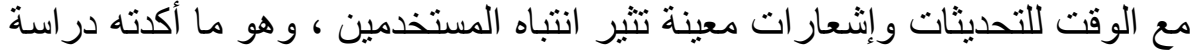

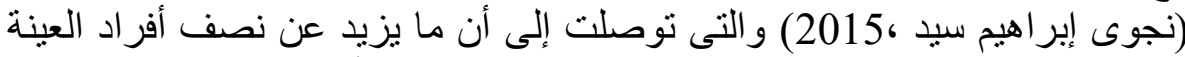

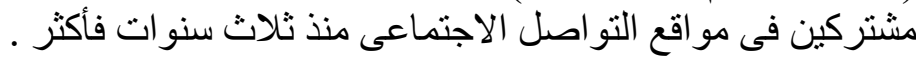


3- معدل استخدام الثباب المصري لمواقع التواصل الاجتماعي:

جدول (4) يوضح معدل استخدام الثباب المصري لمواقع التواصل الاجتماعي

\begin{tabular}{|c|c|c|c|c|}
\hline \multirow{2}{*}{ مستوى المعنوية } & \multirow{2}{*}{25} & \multicolumn{2}{|c|}{ الإجمالي } & \multirow{2}{*}{ معدل استخدام الثباب المصري لمواقع التواصل } \\
\hline & & $\%$ & ك5 & \\
\hline \multirow{4}{*}{0.001} & \multirow{4}{*}{173.555} & 3 & 12 & من 1-3 أيام في الأسبوع \\
\hline & & 54.3 & 217 & من 4-6 أيام فى الأسبوع \\
\hline & & 42.8 & 171 & يوميا \\
\hline & & 100 & 400 & ال الإجمالى \\
\hline
\end{tabular}

يتضح من الجدول السابق أن نسبة 42.8\% من أفر اد العينة يستخدموا مو اقع التو اصل الإل

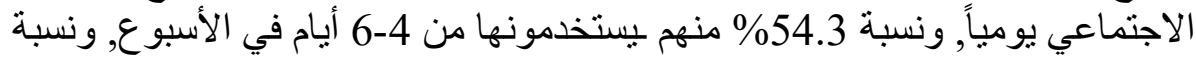

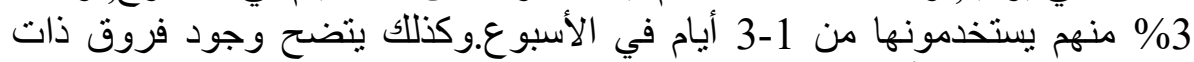

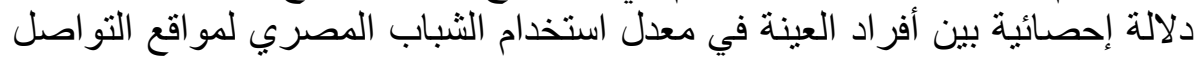

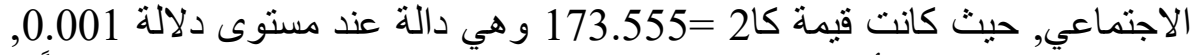
مما يعنى ارتفاع نسبة أفر اد العينة الذين يستخدموا مو اقع التو اصل الصل الاجتماعي يومياً .

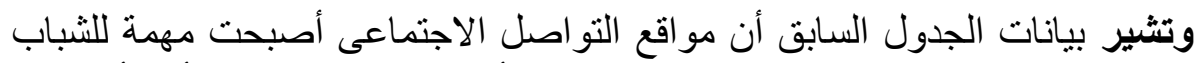

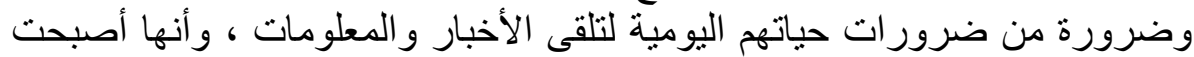

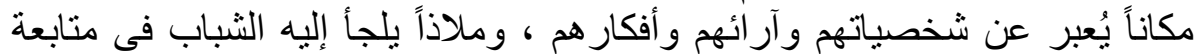

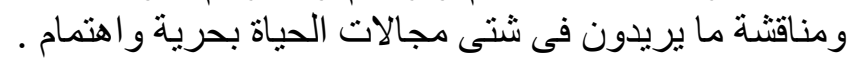

4- عدد الساعات التي تقضيها يومياً في استخدام مواقع التواصل الاجتماعي: جدول (5) يوضح عدد الساعات التي تقضيها يوميا في استخدام مواقع التواصل الاجتماعي مولي

\begin{tabular}{|c|c|c|c|c|}
\hline \multirow{2}{*}{ مستوى المعنوية } & \multirow[t]{2}{*}{ كا } & \multicolumn{2}{|c|}{ الإجمالي } & \multirow{2}{*}{ عدد الساعات التي تقضيها يومياً في استخدام التواعي } \\
\hline & & $\%$ & ك & \\
\hline \multirow[t]{5}{*}{0.001} & \multirow[t]{5}{*}{31.040} & 13 & 52 & ساعة يو مياً \\
\hline & & 30 & 120 & من ساعة الى ساعتين يومياً \\
\hline & & 29 & 116 & ثلاث ساعات يو مياً \\
\hline & & 28 & 112 & اكثر من ثناتث ساعات يو مياً \\
\hline & & 100 & 400 & الإجمالى \\
\hline
\end{tabular}

يتضح من الجدول السابق أن نسبة 30\% من أفراد العينة يقضو ا يومياً في استخدام

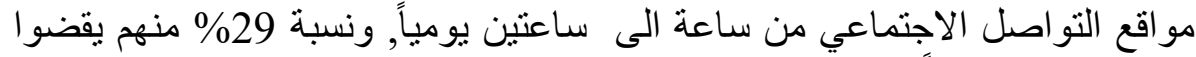

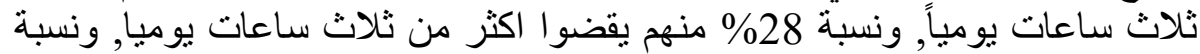

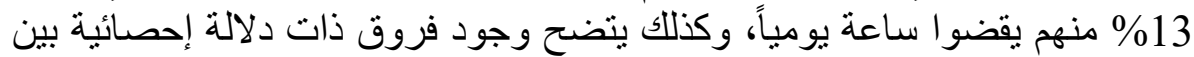

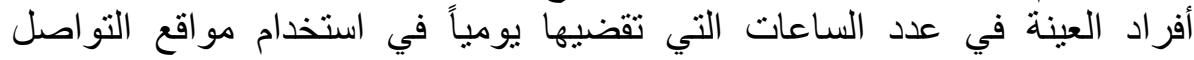

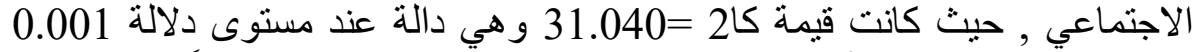

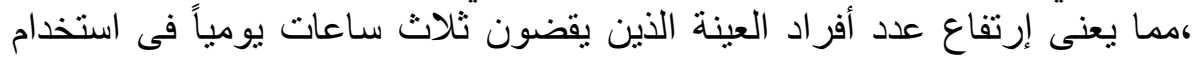

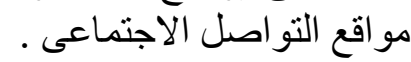


وترى الباحثة أن الاستخدام المتزايد و المكثف من قبل المبحوثين لمواقع التواصل

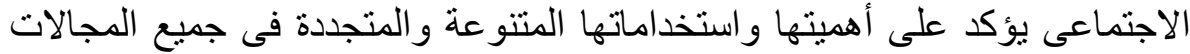

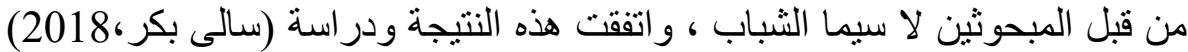

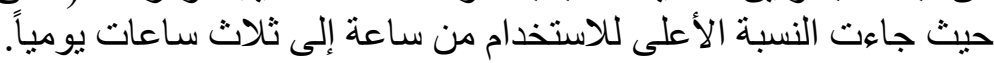

5- الوسيلة التي يستخدمها الثباب المصري عند الاخول على مواقع التو اصل الاجتماعي:

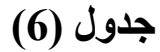

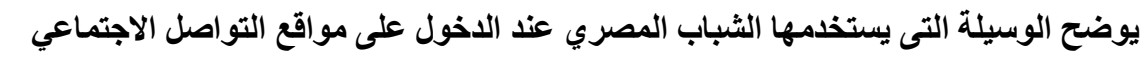

\begin{tabular}{|c|c|c|c|c|}
\hline \multirow{2}{*}{ مستوى المعنوية } & \multirow[t]{2}{*}{215} & \multicolumn{2}{|c|}{ الإجمالي } & \multirow{2}{*}{ 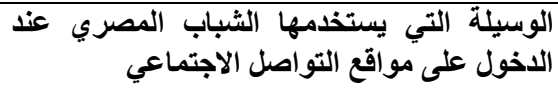 } \\
\hline & & $\%$ & ك & \\
\hline \multirow[t]{6}{*}{0.001} & \multirow[t]{6}{*}{118.250} & 12.3 & 49 & جهاز كمبيوتر عادى فى المنزل \\
\hline & & 15.8 & 63 & لاب توب \\
\hline & & 39.3 & 157 & هاتف ذكى \\
\hline & & 24 & 96 & كمبيوتر لوحى \\
\hline & & 8.8 & 35 & جميع ما سبق \\
\hline & & 100 & 400 & الإجمالى \\
\hline
\end{tabular}

يتضح من الجدول السابق أن نسبة 39.3\% من أفراد العينة يستخدموا عند الدخول

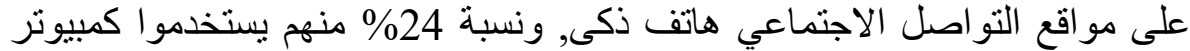

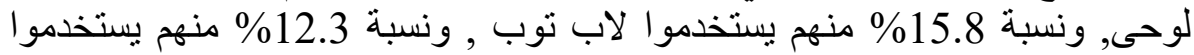

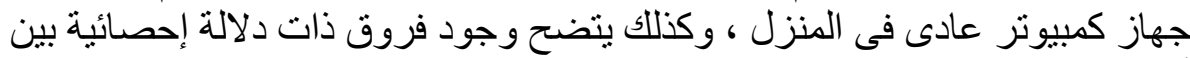

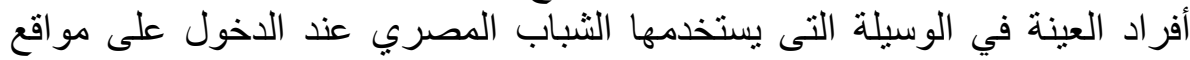

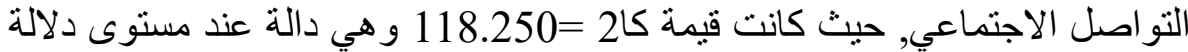
0.001. ,وذللك لارتفاع نسبة أفراد العينة الذين يستخدموا عند الدخول على مواقع التو اصل الاجتماعي هاتف ذكى نئ.

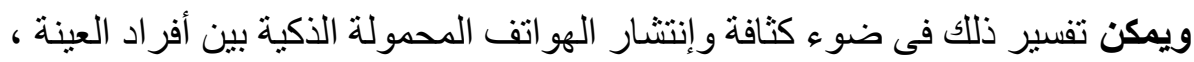

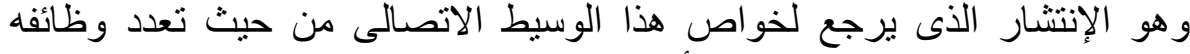

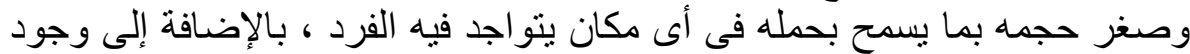

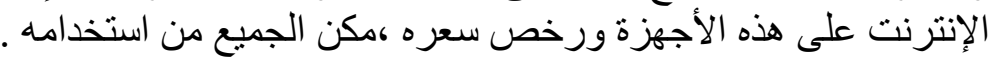

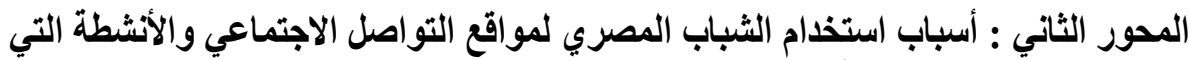
يقومون بها والتعامل مع الأخبار التي تنثر عبر مواقع التّو اصل الاجتماعي: 
6ـ أهم الأسباب التي تجعل الثباب المصري حريصاً على تصفح مواقع التو اصل الاجتماعي .

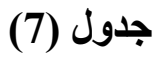

يوضح أهم الأسباب التي تجعل الثباب المصري حريصاً على تصفح مواقع التواصل

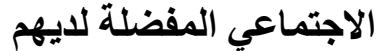

\begin{tabular}{|c|c|c|c|c|c|}
\hline \multirow[t]{2}{*}{ الد الالة } & \multirow[t]{2}{*}{25} & \multirow[t]{2}{*}{ الترتيب } & \multicolumn{2}{|c|}{ ن=إجمالي } & \multirow{2}{*}{ 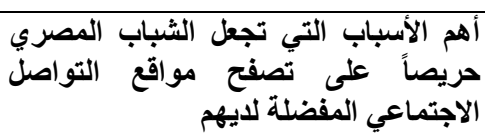 } \\
\hline & & & $\%$ & s & \\
\hline 0.05 & 5.290 & 2 & 55.8 & 223 & نشر الصور ومقاطع الفيديو \\
\hline ا & 0.360 & 5 & 51.5 & 206 & التو اصل مع الأهل و الأصدقاء \\
\hline 0.01 & 9.610 & 1 & 57.8 & 231 & التعرف على أصدقاء جدد \\
\hline 0.089 غير دالة & 2.890 & 7 & 45.8 & 183 & ـ تعليقات ـ تنغريدات) على الصفحات (منشورات \\
\hline 0.01 & 6.760 & 8 & 43.5 & 174 & لقضاء وقت الفراغ \\
\hline ا 0.2710 .0 & 1.210 & 4 & 52.8 & 211 & لمتابعة الأخبار و الأحداث \\
\hline 0.001 & 10.240 & 9 & 42 & 168 & للتعبير عن ر أيى بحرية مطلقة \\
\hline 0.001 & 38.440 & 11 & 34.5 & 138 & الإطلاع على الإعلانات دائما \\
\hline 0.001 & 19.360 & 10 & 39 & 156 & لمسايرة النطور ات الحديثة \\
\hline - l 0.072 غير دالة & 3.240 & 3 & 54.5 & 218 & لزيادة الوعى الثقافى \\
\hline - 0.689 غير دالة & 0.160 & 6 & 49 & 196 & لدعم قضية معينة \\
\hline
\end{tabular}

يتضح من الجدول السابق أن نسبة 57.8\% من أفراد العينة بروا أن أهم الأسباب

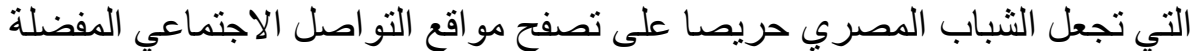

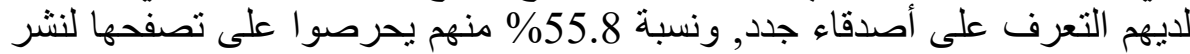

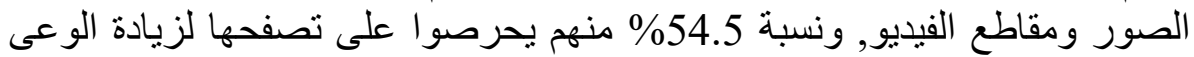
الثقافي, ونسبة 52.8\% منهم يحرصوا على تصفحها لمتابعة الأخبار والأحداث.

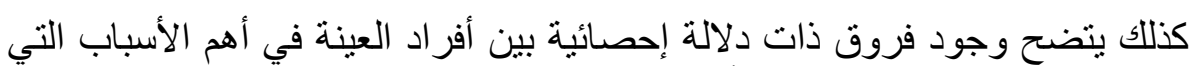

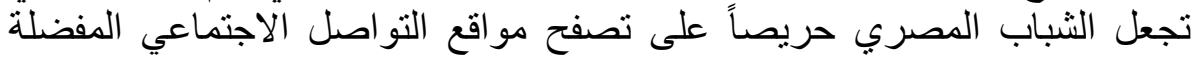

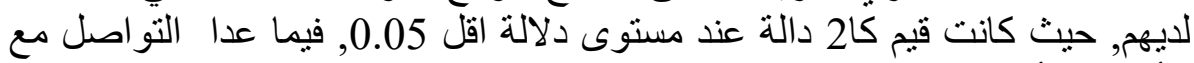

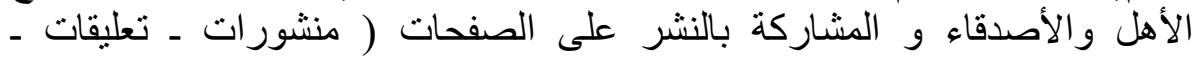

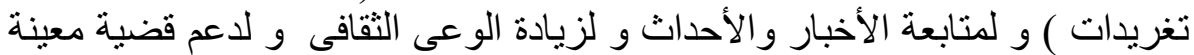

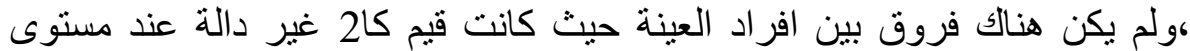

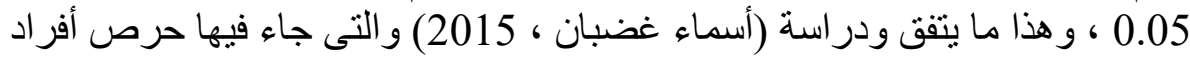

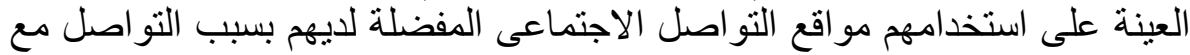
الأصدقاء والأهل فى الترتيب الأول ، يليه تصفح الأخبار بشكل عام ، ثم استخدامه للتسلية وقضاء وقت الفر اغل 
7- أهم الأنشطة التي يمكن أن يقوم بها الثباب المصري من خلال استخدامهم

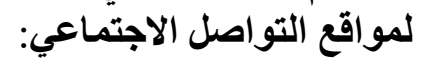

\section{جدول (8)}

يوضح أهم الأنشطة التي يمكن أن يقوم بها الشباب المصري من خلال استخدامهم

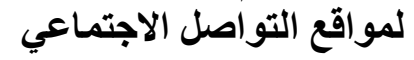

\begin{tabular}{|c|c|c|c|c|c|}
\hline \multirow[t]{2}{*}{ الدلالة 1 د 1} & \multirow[t]{2}{*}{25} & \multirow[t]{2}{*}{ الترتيب } & \multicolumn{2}{|c|}{ ن } & \multirow{2}{*}{ 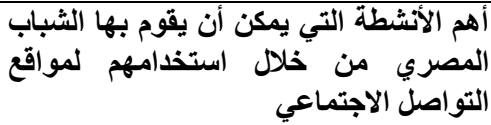 } \\
\hline & & & $\%$ & ك & \\
\hline 0.484 غير دالة & 0.490 & 5 & 51.8 & 207 & متابعة تحديثات الأصدقاء \\
\hline 0.001 & 54.760 & 10 & 31.5 & 126 & تحديث الحالة الخاصة بى \\
\hline 0.05 & 4.840 & 9 & 44.5 & 178 & وفيديوهات مات ينشره الآخرون من صور \\
\hline 0.920 غير دالة & 0.010 & 7 & 49.8 & 199 & 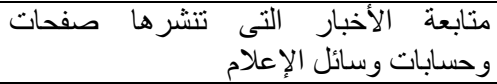 \\
\hline 0.001 & 11.560 & 2 & 58.5 & 234 & التعارف و إنشاء صداقات \\
\hline 0.110 غير دالة & 2.560 & 4 & 54 & 216 & المشاركة بالنشر على الصفحات \\
\hline 0.920 غير دالة & 0.010 & 7 & 49.8 & 199 & التثقيف و الإطلاع على كل ما هو جديد \\
\hline 0.01 & 9.610 & 3 & 57.8 & 231 & استخدامها لأغر اض علمية ومهنية \\
\hline 0.617 غير دالة & 0.250 & 8 & 48.8 & 195 & 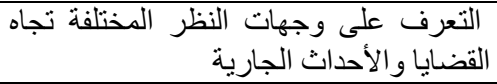 \\
\hline 0.920 غير دالة & 0.010 & 6 & 50.3 & 201 & التسويق الإلكترونى للمنتجات و الخدمات \\
\hline 0.001 & 28.090 & 1 & 63.3 & 253 & الشر اء الإلكترونى من خلالها \\
\hline 0.841 غير دالة & 0.040 & 6 & 50.5 & 202 & مطالعة الكتب \\
\hline
\end{tabular}

يتضح من الجدول السابق أن نسبة 63.3\% من أفراد العينة يروا أن أهم الأنشطة

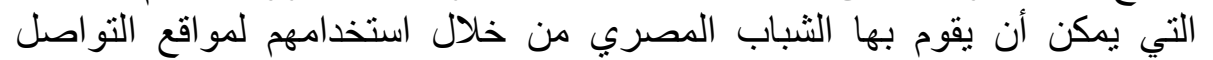

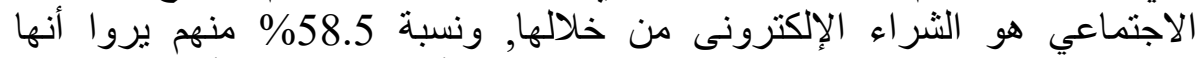

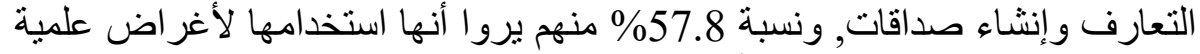
و مهنية, ونسبة 54\% منهم يروا أنها المشاركة بالنشر على على الصفحات.

كذلك يتضح عدم وجود فروق ذات دلالة إحصائية بين أفر اد العينة في أهم الأنشطة

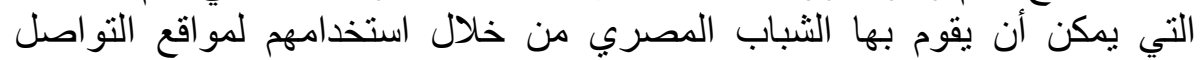

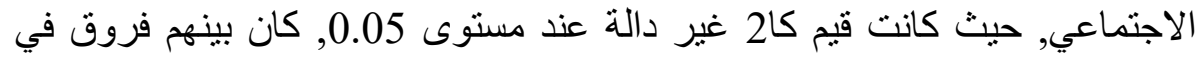

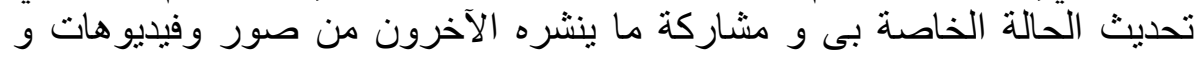

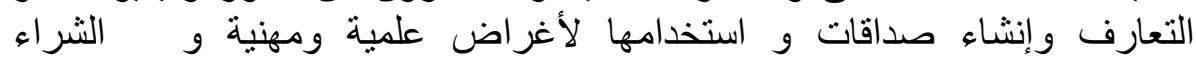
الإلكترونى من خلالها حيث كانت قيم كا2 دالة عند مسنوى دلالة اقل من 0.05.

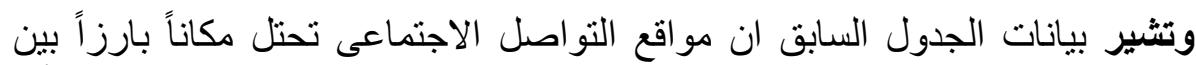

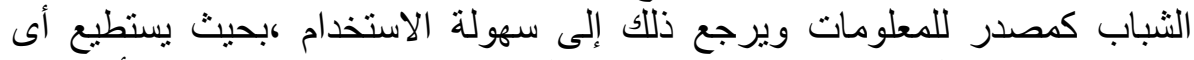

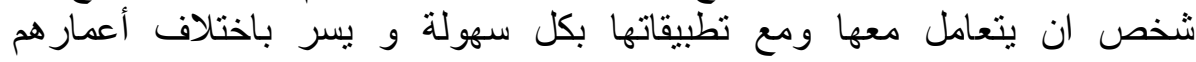




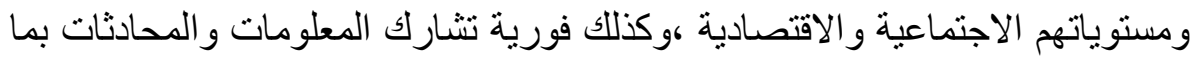

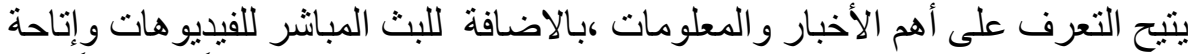

الميزة التشاركية ،كل هذا جعل مواقع التو اصل الاجتماعى أكثر استخداماً وتفضيلاً.

8- نوعية الصفحات التي يفضل الثباب متابعتها على مواقع التواصل الاجتماعي:

جدول (9) يوضح نوعية الصفحات التي يفضل الثباب متابعتها على مواقع

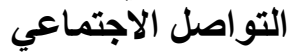

\begin{tabular}{|c|c|c|c|c|c|}
\hline \multirow[t]{2}{*}{ الدح ح 1} & \multirow[t]{2}{*}{25} & \multirow[t]{2}{*}{ الترتيب } & \multicolumn{2}{|c|}{ إجمالي } & \multirow{2}{*}{ 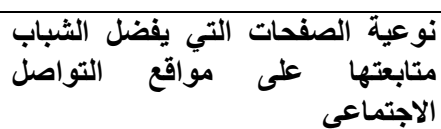 } \\
\hline & & & $\%$ & 5 & \\
\hline 0.001 & 49.000 & 2 & 67.5 & 270 & صفحات رياضية \\
\hline 0.05 & 4.840 & 4 & 44.5 & 178 & صفحات اقتصادية \\
\hline 0.001 & 79.210 & 1 & 72.3 & 289 & صفحات سياسية \\
\hline 0.001 & 72.250 & 8 & 28.8 & 115 & صفحات اجتماعية \\
\hline 0.001 & 27.040 & 7 & 37 & 148 & صفحات دينية \\
\hline 0.001 & 24.010 & 3 & 62.3 & 249 & صفحات ثقافية \\
\hline 0.05 & 6.250 & 5 & 43.8 & 175 & صفحات ساخرة \\
\hline 0.001 & 12.250 & 6 & 41.3 & 165 & صفحات تعليمية \\
\hline
\end{tabular}

يتضح من الجدول السابق أن نسبة 72.3\% من أفراد العينة يروا

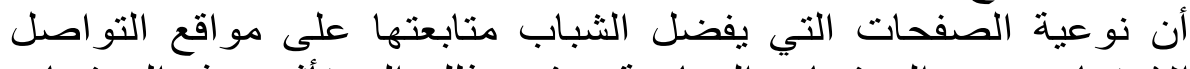

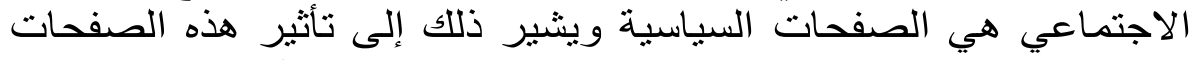

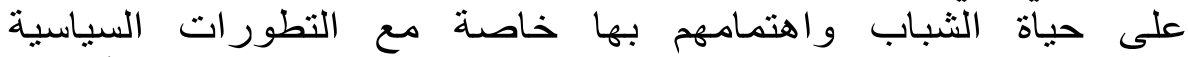

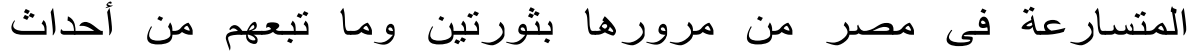
وموضو عات سياسية مختلفة وسعى الثباب للمشناركة السياسية و وإيصال

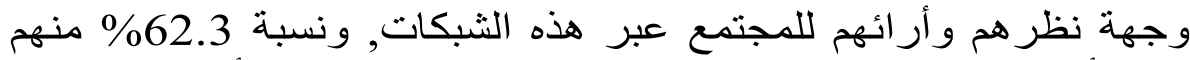

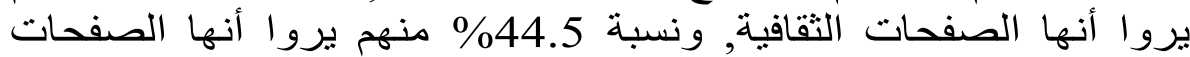

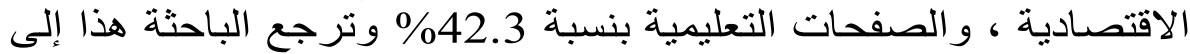

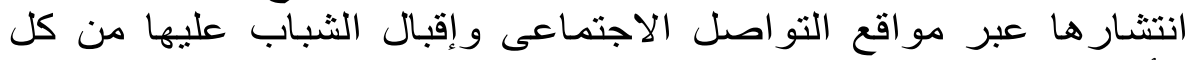

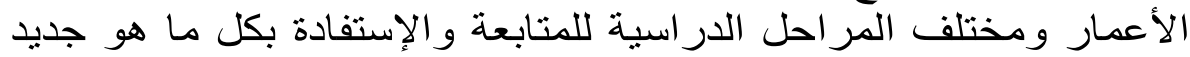

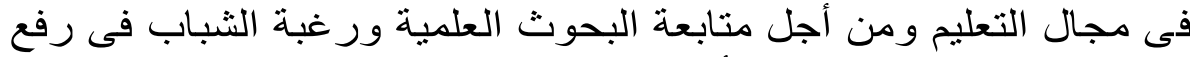

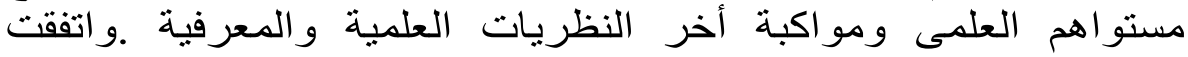
ودر اسة (سالى محمد،2018) التى تصواكية تصدرت التهات الصفحات السياسية قائمة الصفحات التى يتابعها الثباب عينة الدر اسة.

كذلك يتضح وجود فروق ذات دلالة إحصائية بين أفراد العينة في نوعية

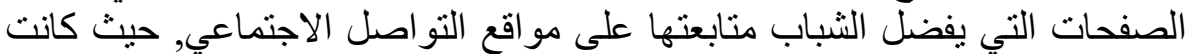
قيم كا2 دالة عند مستوى دلالة اقل من 0.05. 
9- مدى متابعة الأخبار باستتمرار على مواقع التواصل الاجتماعي:

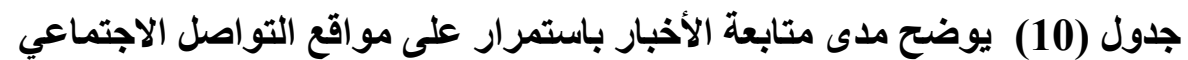

\begin{tabular}{|c|c|c|c|c|}
\hline \multirow{2}{*}{ المعنوى مستة } & \multirow[t]{2}{*}{ كا2 } & \multicolumn{2}{|c|}{ الإجمالي } & \multirow{2}{*}{ التواصل متابعة الأختماعي م باستمرار على مواقع } \\
\hline & & $\%$ & ك & \\
\hline \multirow[t]{4}{*}{0.001} & \multirow[t]{4}{*}{163.520} & 36 & 144 & دائما \\
\hline & & 58 & 232 & أحيانا \\
\hline & & 6 & 24 & $y$ \\
\hline & & 100 & 400 & الإجمالى \\
\hline
\end{tabular}

يتضح من الجدول السابق أن نسبة 36\% من أفر اد العينة يتابعوا الأخبار باستمرار على مو اقع التو اصل الاجتماعي, ونسبة 58\% منهم يتابعونها أحيانا, ونسبة 6 \% ل الا يتابعونها.

كذلك يتضح وجود فروق ذات دلالة إحصائية بين أفراد العينة في مدى الإئ

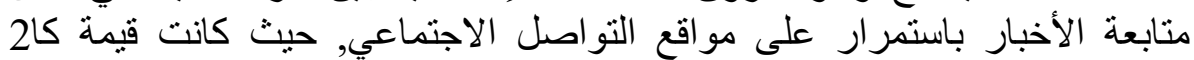

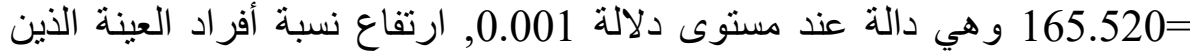

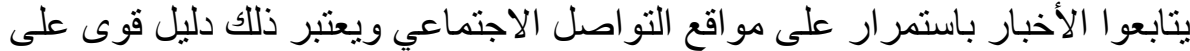

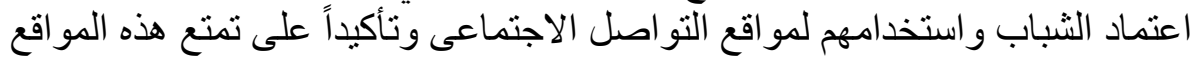
بالوظيفة الإعلامية الإخبارية . 10- أسباب متابعة الثباب المصري للأخبار على مواقع التواصل الاجتماعي: جدول (11)

يوضح أسباب متابعة الثباب المصري للأخبار على مواقع التواصل الاجتماعي

\begin{tabular}{|c|c|c|c|c|c|}
\hline \multirow[t]{2}{*}{ 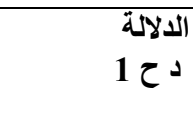 } & \multirow[t]{2}{*}{25} & \multirow[t]{2}{*}{ الترتيب } & \multicolumn{2}{|c|}{ ن=376 إجمالي } & \multirow[t]{2}{*}{ على مواقع التواصل الثل الاجتماعي المصري ل للأخبار } \\
\hline & & & $\%$ & ك & \\
\hline 0.122 غير دالة & 2.394 & 3 & 46 & 173 & الاجتماعى والمريعة وسعلة الإنتشار مواقع التواصل \\
\hline 0.180 غير دالة & 1.798 & 1 & 64.5 & 234 & الأخبار على على مواقع التواصل الحية الاجتماعى \\
\hline 0.001 & 22.511 & 2 & 45.2 & 175 & التقلبدية وشكل لاضيى فضبار فلى وسائل الإعلام \\
\hline 0.01 & 9.574 & 4 & 42 & 158 & مصير واضحر الأخبار فى وسائل الإعلام الأخرى \\
\hline 0.001 & 18.766 & 5 & 38.8 & 146 & شكل الأخبار فى وسائل الإعلام غير و اضح \\
\hline
\end{tabular}

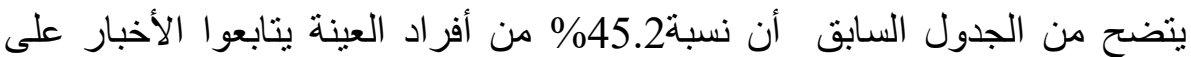

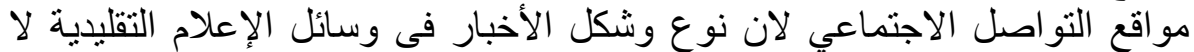

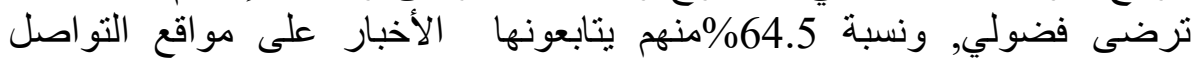


الاجتماعي مدعمة بالصورة الحية و الفيديو, ونسبة 46\% منهم يتابعونها لان الأخبار

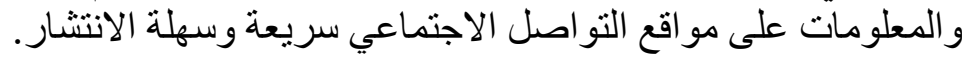

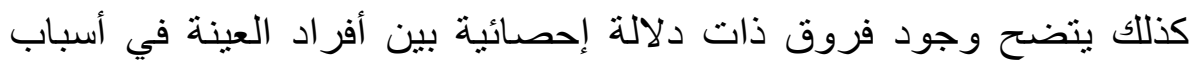

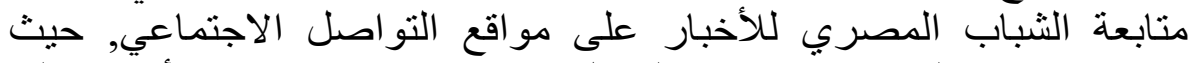

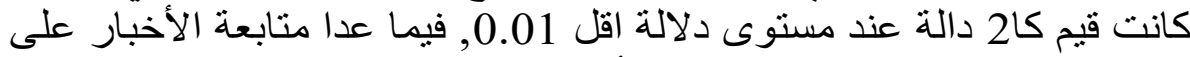

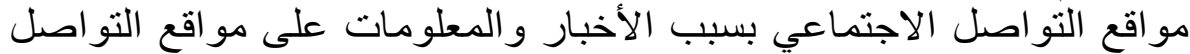

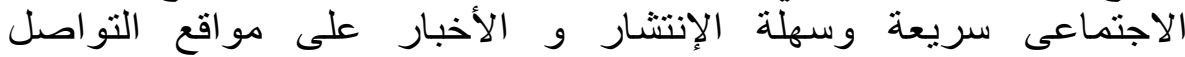

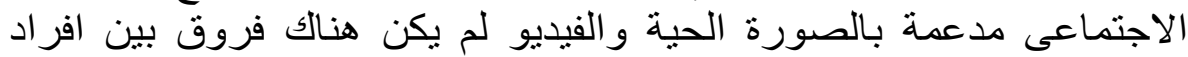
العينة حيث كانت قيم كاعث فير دالة دالة عند مستوى 0.05. 11- ما يقوم به الثباب في حالة اهتمامهم بخبر أو حدث أو موضوع عبر مواقع داقع

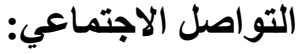

$$
\text { جدول (12) }
$$

يوضح ما يقوم به الشباب في حالة اهتمامهم بخبر أو حدث أو موضوع عبر مواقع التواصل الاجتماعي

\begin{tabular}{|c|c|c|c|c|}
\hline مستوى & \multirow[t]{2}{*}{25} & \multicolumn{2}{|c|}{ الإجمالي } & \multirow{2}{*}{ موضوع عبر مواقه الثباب في حالة اهتمامهم بخبر أو حلث أو التواعي } \\
\hline الم حمنوية & & $\%$ & 5 & \\
\hline \multirow[t]{7}{*}{0.001} & \multirow[t]{7}{*}{37.840} & 23.4 & 88 & قر اءة العناوين ومشاهدة الصور فقط \\
\hline & & 15.4 & 58 & اختيار جزء من الموضوع وقر اءته قراءة عميقة \\
\hline & & 12.8 & 48 & قر اعة الموضوع كاملا أو معظمه قر اعة سريعة \\
\hline & & 24.5 & 156 & الاحتماعرة تعليقات المستخدمين على مواقع التواصل \\
\hline & & 12.5 & 47 & انتقل إلى مصدر الخبر نفسه للتأكد من صحة المعلومات \\
\hline & & 11.4 & 43 & والتأكد من مع الأصداء لمعرفة تفاصيل الخبر بالكامل \\
\hline & & 100 & 427 & الإجمالى \\
\hline
\end{tabular}

يتضح من الجدول السابق أن نسبة 24.5\% من أفر اد العينة في حالة اهتمامهم بخبر

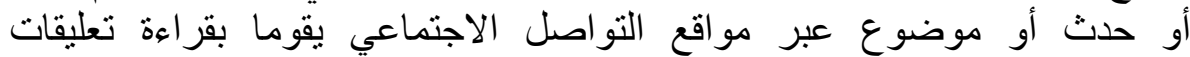

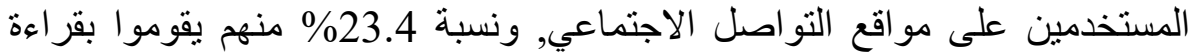

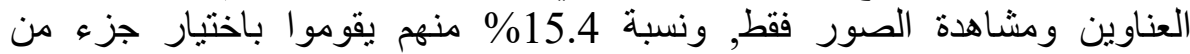

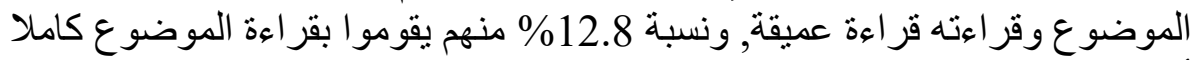
أو معظمه قر اءة سريعة.

كذللك يتضح وجود فروق ذات دلالة إحصائية بين أفر اد العينة في ما يقوم به الثباب

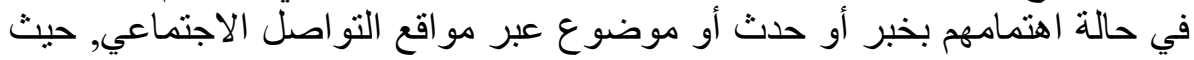
كانت قيمة كا2 =37.840 و هي دالة عند مستوى دلالة 
12- مدى مصداقية مواقع التواصل الاجتماعي فى نشر الأخبار والمعلومات المدعمة بالصور الحية والفيديو: مولئ القئ

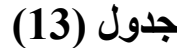

يوضح مدى مصداقية مواقع التواصل الاجتماعي فى نشر الأخبار والمعلومات

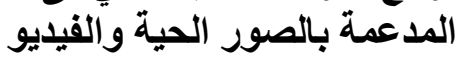

\begin{tabular}{|c|c|c|c|c|}
\hline \multirow{2}{*}{ د مستوى المعنوية } & \multirow[t]{2}{*}{ كا2 } & \multicolumn{2}{|c|}{ الإجمالي } & 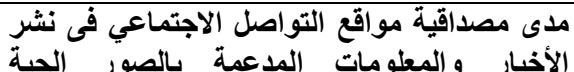 \\
\hline & & $\%$ & ك & والفيذيو والمعلومات الم \\
\hline \multirow[t]{4}{*}{0.001} & \multirow[t]{4}{*}{41.590} & 26.9 & 125 & صادقة \\
\hline & & 48.9 & 184 & صـادقة إلى حد ما \\
\hline & & 24.2 & 91 & غير صـادقة \\
\hline & & 100 & 400 & الجمـلة \\
\hline
\end{tabular}

يتضح من الجدول السابق أن نسبة 26.9\% من أفر اد العينة يروا أن مو اقع التو اصل

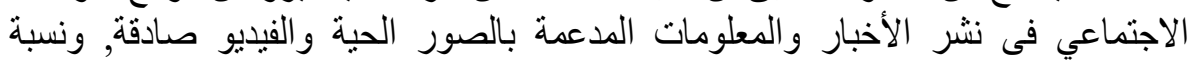

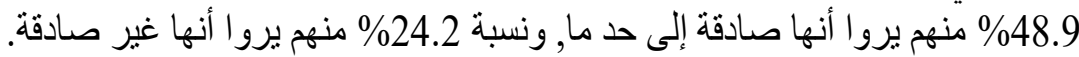

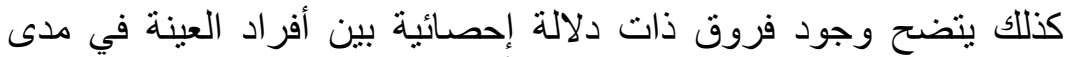

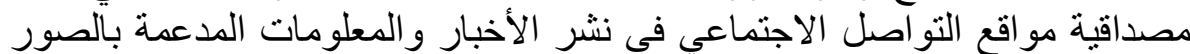

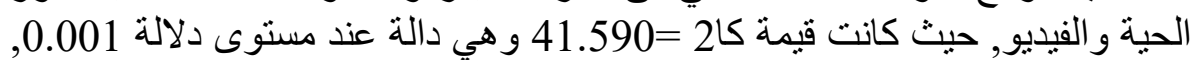
ارتفاع نسبة افر اد العينة الذين يروا أن مواقع التواصل الفي الاجتماعي فى نشر الأخبار

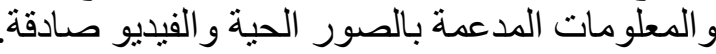

13- مدى سرعة انتشار الأخبار والمعلومات عبر مواقع التواصل الاجتماعي:

جدول (14) يوضح مدى سرعة انتثار الأخبار والمطلومات عبر مواقع التواصل الاجتماعي

\begin{tabular}{|c|c|c|c|c|}
\hline مستوى & \multirow[t]{2}{*}{ كا2 } & \multicolumn{2}{|c|}{ الإجمالي } & \multirow{2}{*}{ التواصل سرعة الاجتماعي الأخبار والمعلومات عبر مواقع } \\
\hline د المعنوية & & $\%$ & 5 & \\
\hline \multirow[t]{4}{*}{0.001} & \multirow[t]{4}{*}{111.468} & 52.7 & 198 & سريعة \\
\hline & & 38.3 & 144 & متوسطة \\
\hline & & 9 & 58 & بطيئة \\
\hline & & 100 & 400 & الإجمالى \\
\hline
\end{tabular}

يتضح من الجدول السابق أن نسبة 52.7\% من أفراد العينة يروا أن سرعة انتشار

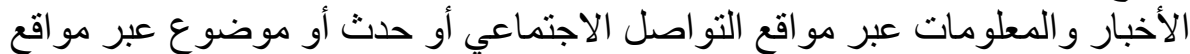

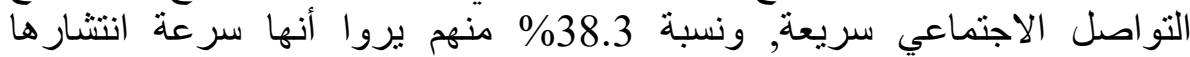
متوسطة, ونسبة 99\% منهم يروا أن سرعة ونسة انتشار ها بطيئة. كذلك يتضح وجود فروق ذات دلالة إحصائية بين أفر اد العينة في مدى سر عة التها انتشار

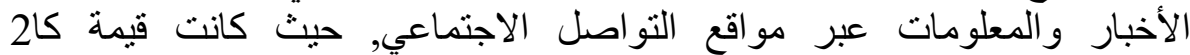


111.468=

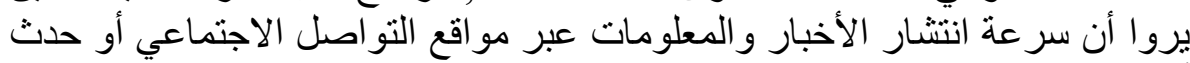
أو موضوع عبر مو اقع التو اصل الاجتماعي سريعة.

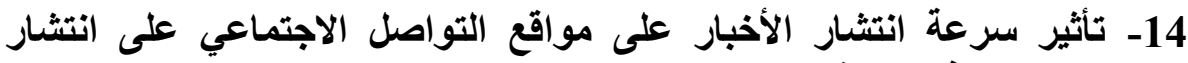

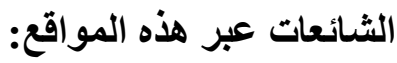

جدول (15)

يوضح مدى سرعة انتثار الأخبار والمعلومات عبر مواقع التواصل الاجتماعي

\begin{tabular}{|c|c|c|c|c|}
\hline \multirow{2}{*}{ دالمنتوية } & \multirow[t]{2}{*}{ كا2 } & \multicolumn{2}{|c|}{ الإجمالي } & \multirow{2}{*}{ 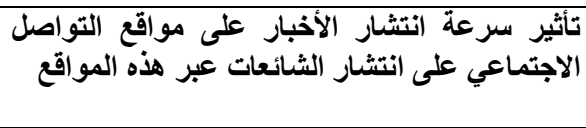 } \\
\hline & & $\%$ & 5 & \\
\hline \multirow[t]{6}{*}{0.001} & \multirow[t]{6}{*}{144.771} & 34.3 & 129 & عالية جدا \\
\hline & & 34.6 & 130 & عالية \\
\hline & & 16.5 & 62 & متوسط \\
\hline & & 10.4 & 39 & منخفضة \\
\hline & & 4.3 & 16 & منخفضة جدا \\
\hline & & 100 & 376 & الجمـلة \\
\hline
\end{tabular}

يتضح من الجدول السابق أن نسبة 34.3\% من أفراد العينة يروا أن نأثير

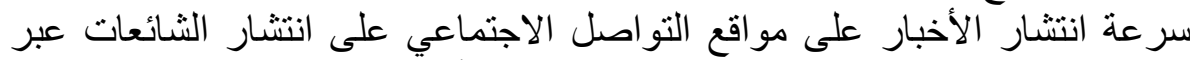

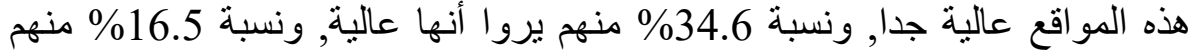

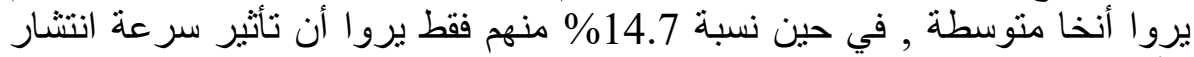

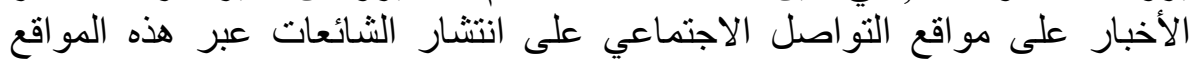
منخفض ومنخفض جدا. كذلك يتضح وجود فروف ذات دلالة إحصائية بين أفراد العينة في تأثير

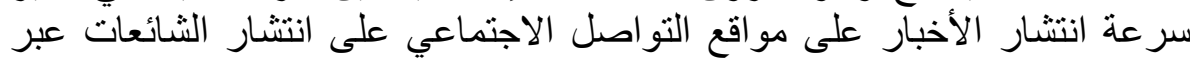
هذه المو اقع, حيث كانت قيمة كال2 =

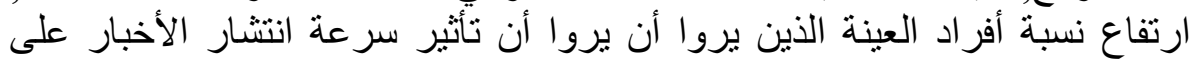

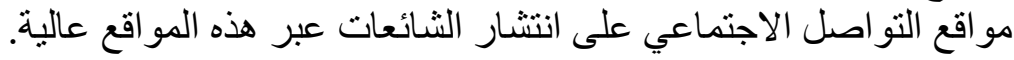

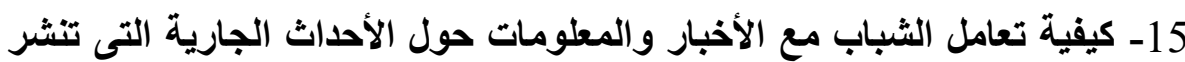

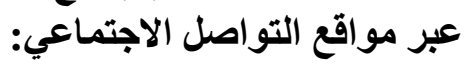


جدول (16) يوضح كيفية تعامل الشباب مع الأخبار والمعلومات حول الأحداث الجارية التى تنشر عبر مواقع التواصل الاجتماعي ن=376

\begin{tabular}{|c|c|c|c|c|c|c|c|c|}
\hline \multirow{2}{*}{ الاتجاه } & \multirow{2}{*}{ المتوسط } & \multicolumn{2}{|c|}{ معارض } & \multicolumn{2}{|c|}{ محايد } & \multicolumn{2}{|c|}{ موافق } & \multirow{2}{*}{ تعامل الثباب مع الاخبارولالأحلاث الاستجابة } \\
\hline & & $\%$ & 5 & $\%$ & ك & $\%$ & 5 & \\
\hline موافق & 2.75 & 7.2 & 27 & 9.8 & 37 & 83 & 312 & 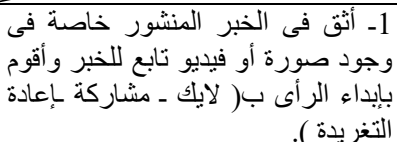 \\
\hline موافق & 2.42 & 12.5 & 47 & 32.7 & 123 & 54.8 & 206 & 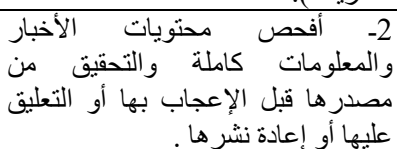 \\
\hline معارض & 1.39 & 64.5 & 258 & 22.9 & 86 & 8.5 & 32 & 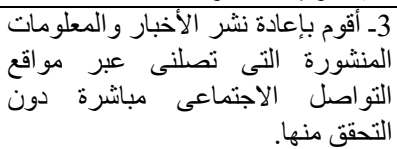 \\
\hline محايد & 1.75 & 43.6 & 163 & 36.3 & 145 & 18.1 & 68 & 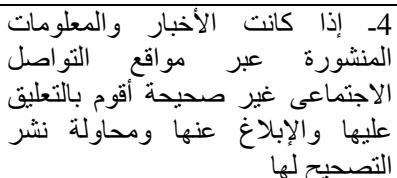 \\
\hline محايد & 1.67 & 47.1 & 177 & 38.8 & 146 & 14.1 & 53 & 5ـ أكتفى بمتابعة الخبر دون إضافة أى مصد \\
\hline معارض & 1.61 & 42.6 & 160 & 54.3 & 204 & 3.2 & 12 & 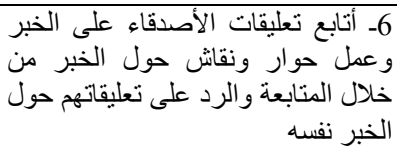 \\
\hline محايد & 1.70 & 42.3 & 159 & 44.9 & 169 & 12.8 & 48 & 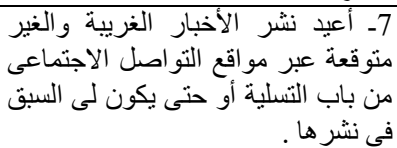 \\
\hline معارض & 1.45 & 61.4 & 231 & 31.4 & 118 & 7.2 & 27 & 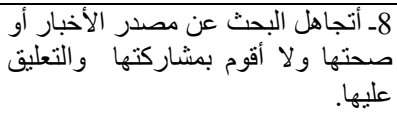 \\
\hline
\end{tabular}

\section{يتضح من الجدول السابق أن الثباب يتعامل مع الأخبار والمعلومات حول}

\section{الأحداث الجارية التى تنشر عبر مواقع التواصل الاجنيان التماعي هي:}

ـ أنق فى الخبر المنشور خاصة فى وجود صورة أو فيديو تابع للخبر و أقوم بإبداء

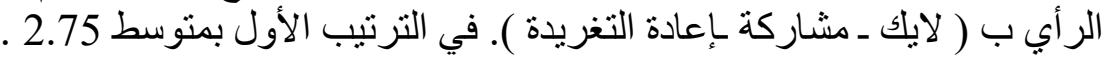

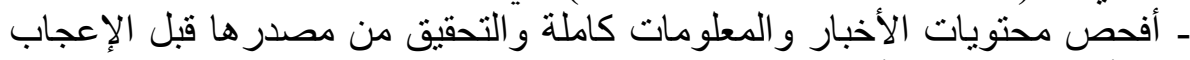
بها أو التعليق عليها أو إعادة نشر ها في الترتيب الثاني بمتوسط 2.42.

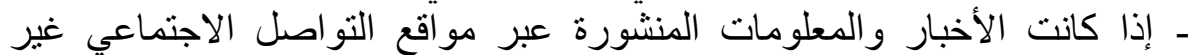

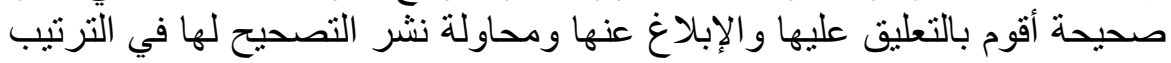




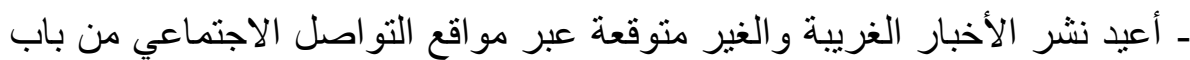

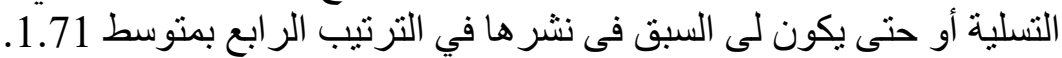

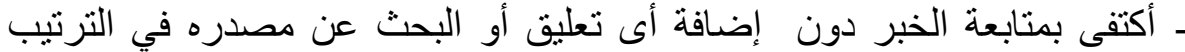

الخامس بمتوسط ابعة 1.67.

المحور الثالث : الثائعات عبر مواقع التواصل الاجتماعي وعلاقتها بمستوى القلق

السياسي لاى الثباب المصري:

16- ماهية الثائعات عبر مواقع التواصل الاجتماعى:

جدول (17) يوضح ماهية الشائعات عبر مواقع التواصل الاجتماعى ن=400

\begin{tabular}{|c|c|c|c|c|c|c|c|c|}
\hline \multirow[t]{2}{*}{ الاتجاه } & \multirow{2}{*}{ المرجح } & \multicolumn{2}{|c|}{ معارض } & \multicolumn{2}{|r|}{ محايد } & \multicolumn{2}{|r|}{ موافقي } & \multirow{2}{*}{ ماهية الثائعات } \\
\hline & & $\%$ & ك & $\%$ & ك & $\%$ & ك & \\
\hline مو افق & 2.71 & 8.5 & 34 & 12.5 & 50 & 79 & 316 & 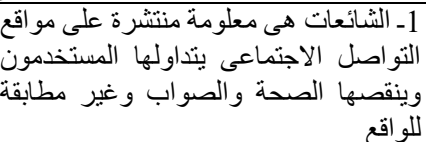 \\
\hline مو افق & 2.37 & 12.8 & 51 & 37.5 & 150 & 49.8 & 199 & 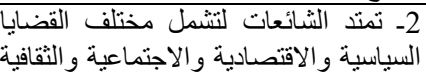 \\
\hline مو افق & 2.61 & 12 & 48 & 14.8 & 59 & 73.3 & 293 & 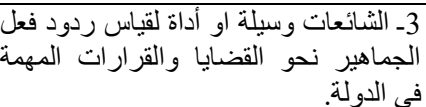 \\
\hline مو افق & 2.38 & 13.8 & 55 & 34.3 & 137 & 52 & 208 & 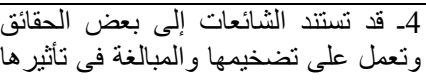 \\
\hline مو افق & 2.66 & 9.8 & 39 & 14.8 & 59 & 75.5 & 302 & موثوق لا تشتند الثائعة إلى مصدر أو مصادر \\
\hline مو افق & 2.36 & 14 & 56 & 35.8 & 143 & 50.3 & 201 & و الغموض تستخدم بعض الثائعة لمواجهة التعتيم \\
\hline محايد & 2.33 & 9.3 & 37 & 48.3 & 193 & 42.5 & 170 & 7 و قد حقيقى . \\
\hline
\end{tabular}

يتضح من الجدول السابق أن الثباب يرى ماهية الثائعات عبر مواقع التواصل

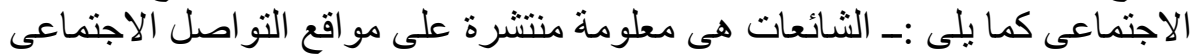

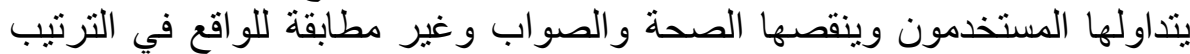

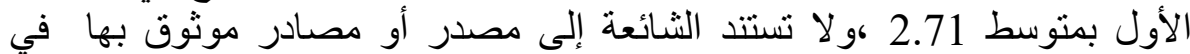

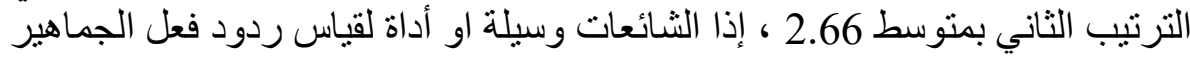

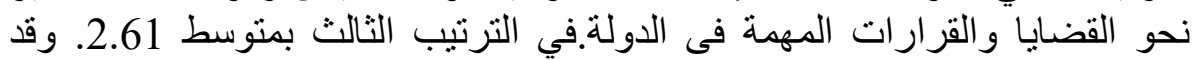

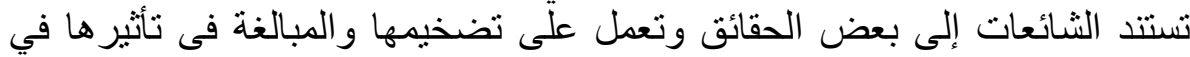
الترتيب الرابع بمتوسط 2.38 ،وتمند الثائعات لتشمل مختلف القضايا النياسية و الاقتصادية والاجتماعية والثقافية في الترتيب الخامس بمتوسط 2.37.

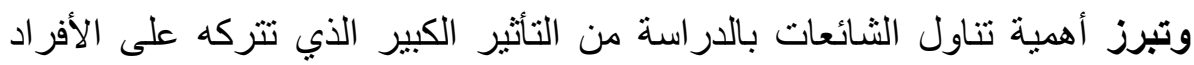

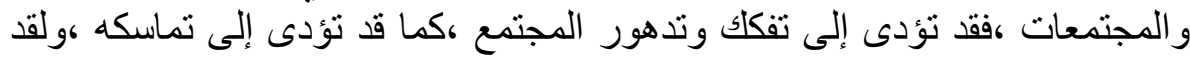




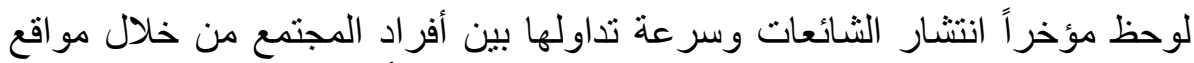

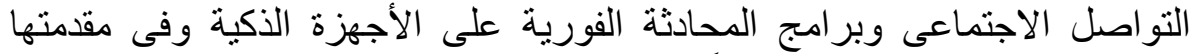

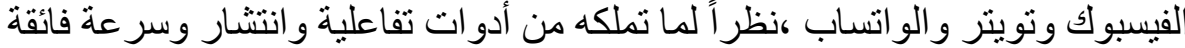
على التشهير و إثارة البلبلة والتأثثر على الثباب .

17- أهداف الشائعات التي تنشر عبر مواقع التواصل الاجتماعي من وجهة نظر

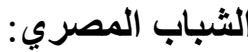
جدول (18) يوضح أهداف الثائعات التى تنشر عبر مواقع التواصل الاجتماعي من وجهة نظر الثباب المصري

\begin{tabular}{|c|c|c|c|c|c|}
\hline \multirow[t]{2}{*}{ الالالة } & \multirow[t]{2}{*}{25} & \multirow[t]{2}{*}{ التزتيب } & \multicolumn{2}{|c|}{ ن } & \multirow[t]{2}{*}{ 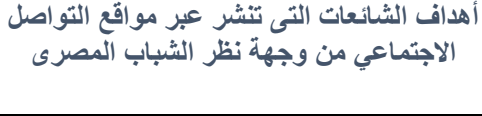 } \\
\hline & & & $\%$ & 5) & \\
\hline 0.001 & 54.760 & 4 & 68.5 & 274 & تفكاك وحدة المجتمع. \\
\hline 0.841 غير دالة & 0.040 & 5 & 49.5 & 198 & تدمير النظام القيمي و السلام المجتمعي \\
\hline 0.001 & 100.000 & 1 & 75 & 300 & إثارة البلبلة و الفوضى بين الأفر اد . . \\
\hline 0.001 & 60.840 & 3 & 69.5 & 278 & في الكجتمع ـ الكرة و الخصومة و البغضاء بين الأفر اد \\
\hline 0.001 & 60.840 & 3 & 69.5 & 278 & إثارة القلاقل و الفتن داخل المجتمع . \\
\hline 0.617 غير دالة & 0.250 & 6 & 48.8 & 195 & عدم الاستقر ار النفسي و القلق السياسي . \\
\hline 0.001 & 73.960 & 2 & 71.5 & 286 & يضعف الثقة بأداء المؤسسات الحكومية . \\
\hline
\end{tabular}

يتضح من الجدول السابق أن نسبة 75\% من أفراد العينة يروا أن أهداف الثائعات التي تنتر

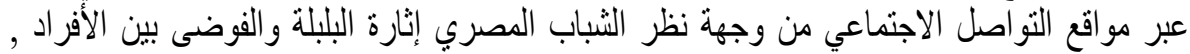

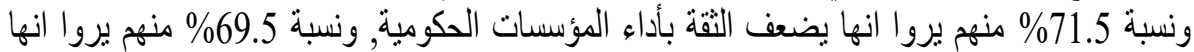
نشر الكر اهية والخصومة والبغضاء بين الأفراد فى المجتمع, ونسبة 69.5\% منهم يروا انها إثارة القلاقل

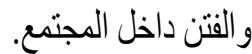
كذلك يتضح وجود فروق ذات دلالة إحصائية بين أفراد العينة في أهداف

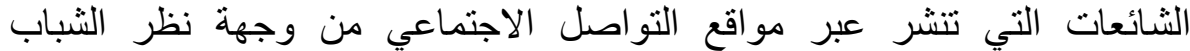

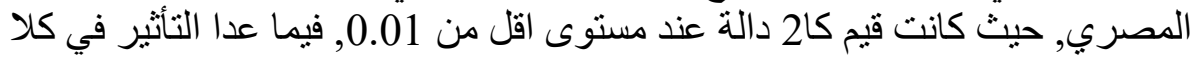

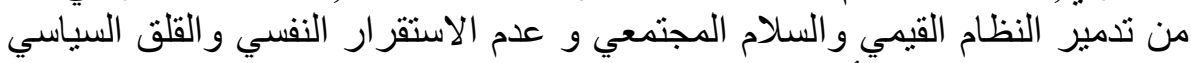

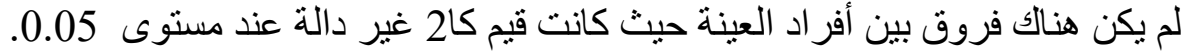

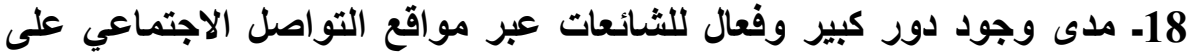

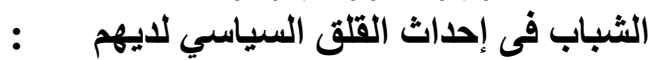

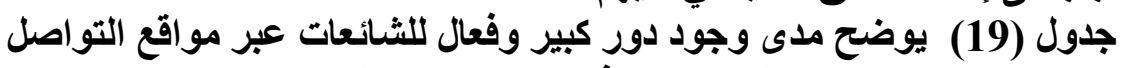

\begin{tabular}{|c|c|c|c|c|}
\hline \multirow{2}{*}{ 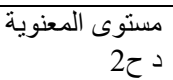 } & \multirow[t]{2}{*}{ كا" } & \multicolumn{2}{|c|}{ 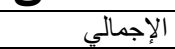 } & \multirow{2}{*}{ 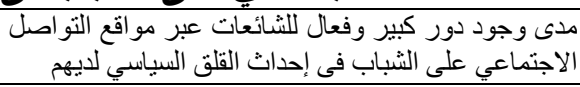 } \\
\hline & & $\%$ & ك & \\
\hline \multirow[t]{4}{*}{0.001} & \multirow[t]{4}{*}{133.505} & 41.5 & 166 & نعرم \\
\hline & & 51.8 & 207 & أحبانا \\
\hline & & 6.8 & 27 & $\gamma$ \\
\hline & & 100 & 400 & الإجمالى \\
\hline
\end{tabular}


يتضح من الجدول السابق أن نسبة 41.5\% من أفراد العينة يروا وجود دور كبير

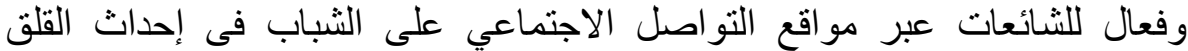
السياسي لديهر, ونسبة 51.8\% منهم يروا وجوده أحيانا , ونسبة 6.8 \%

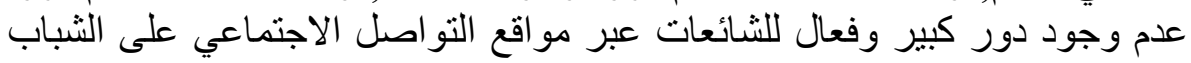
فى إحداث القلق السياسي لديهم.

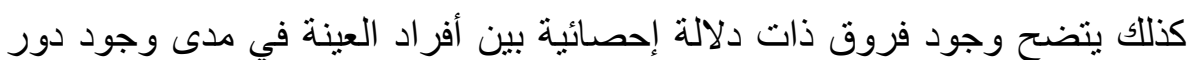
كبير وفعال للشائعات عبر مواقع التواصل الاجتماعي على الثباب في إنى إحداث القلق

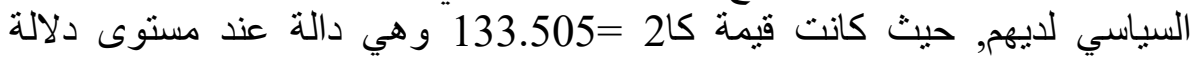

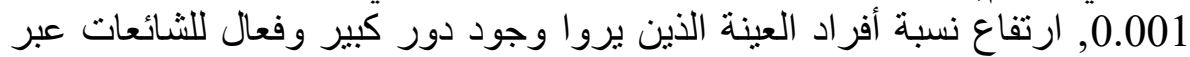
مواقع التو اصل الاجتماعي على الثباب فى إحداث القلق السياسي لديهم.

19-أوقات بروز الثائعات عبر مواقع التواصل الاجتماعي وعلاقتها بمستوى القلق

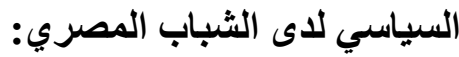

\section{جدول (20)}

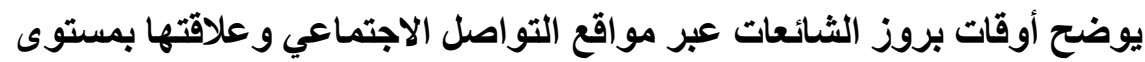
القلق السياسي لاتى الثباب المصري

\begin{tabular}{|c|c|c|c|c|}
\hline \multirow{2}{*}{ المعنوية } & \multirow[t]{2}{*}{25} & \multicolumn{2}{|c|}{ الإجمالي } & \multirow{2}{*}{ 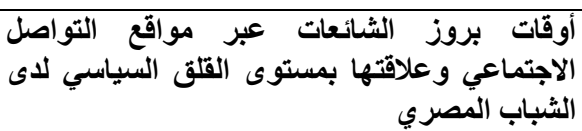 } \\
\hline & & $\%$ & إ & \\
\hline \multirow[t]{7}{*}{0.001} & \multirow[t]{7}{*}{131.450} & 30.3 & 121 & أجو اء الترقب " \\
\hline & & 30 & 120 & وقت الأزمات \\
\hline & & 8.3 & 33 & الانقلابات \\
\hline & & 10 & 40 & الحروب \\
\hline & & 10.5 & 42 & العمليات الإر هابية في المجتمع \\
\hline & & 11 & 44 & وقت الثور ات \\
\hline & & 100 & 400 & الإجمالى \\
\hline
\end{tabular}

يتضح من الجدول السابق أن نسبة 30.3\% من أفراد العينة يروا أن أوقات أبرات

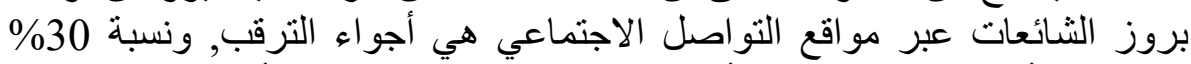

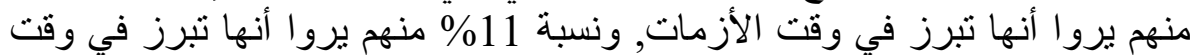

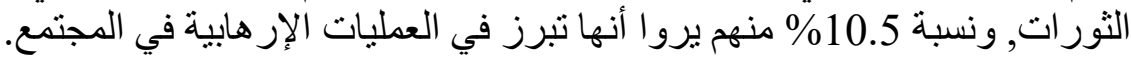
كذلك يتضح وجود فروق ذات دلالة إحصائية بين أفراد العينة في مدى التى

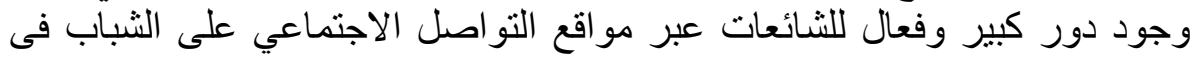

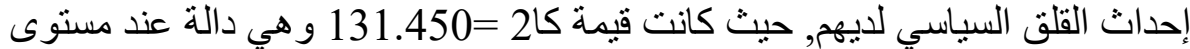

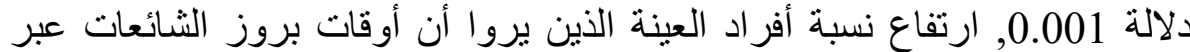

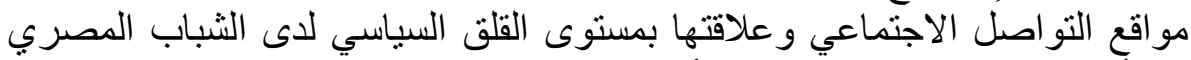

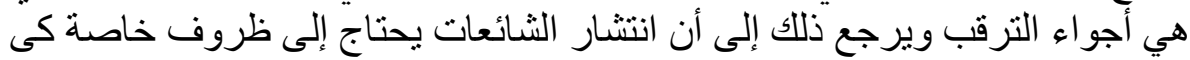




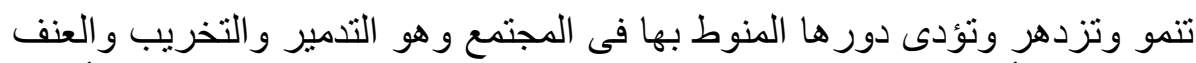

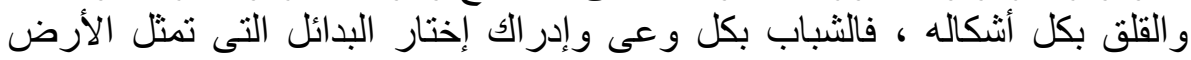
الخصبة لنمو وازدهار الثائعات ووضعها في مقدمة البدائل التى اختار ها ووجد النها أنها

تتمشى معهد .

20- دور الثائعات المنشورة عبر مواقع التواصل الاجتماعي فى صناعة القلق بلق

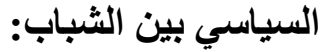

جدول (21) يوضح دور الثائعات المنشورة عبر مواقع التواصل الاجتماعي فى التي صناعة القلق السياسي بين الثباب الثراب

\begin{tabular}{|c|c|c|c|c|}
\hline \multirow{2}{*}{ المعنوية } & \multirow[b]{2}{*}{215} & \multicolumn{2}{|c|}{ الإجمالي } & \multirow{2}{*}{ 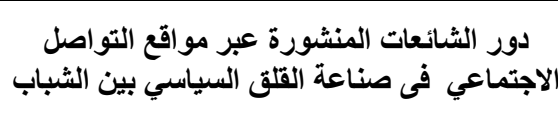 } \\
\hline & & $\%$ & 5 & \\
\hline \multirow{6}{*}{0.001} & \multirow{6}{*}{233.950} & 25.8 & 103 & كبير جدا \\
\hline & & 46.3 & 185 & كبير \\
\hline & & 17.8 & 71 & متوسط \\
\hline & & 5.3 & 21 & ضعيف \\
\hline & & 5 & 20 & ضعيف جدا \\
\hline & & 100 & 400 & الإجمالى \\
\hline
\end{tabular}

يتضح من الجدول السابق أن نسبة 25.8\% من أفراد العينة يروا أن دور

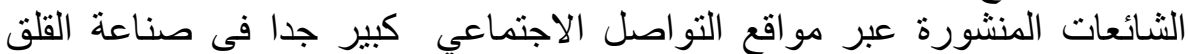

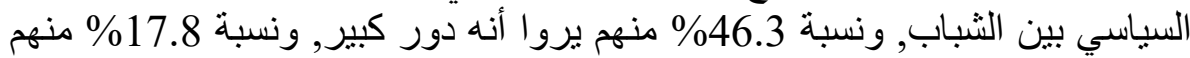

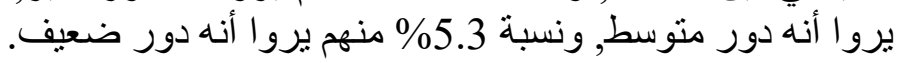

كذلك يتضح وجود فروق ذات دلالة إحصائية بين أفراد العينة في دور

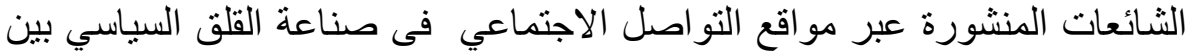

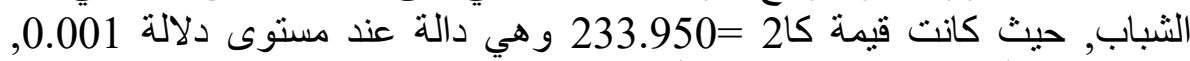

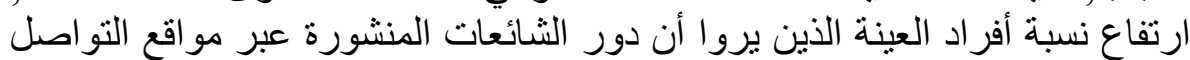

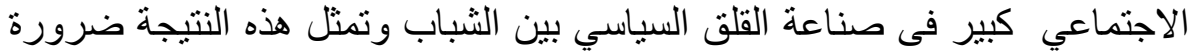

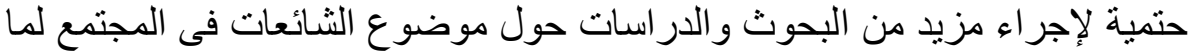

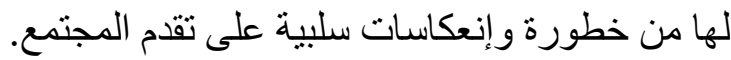

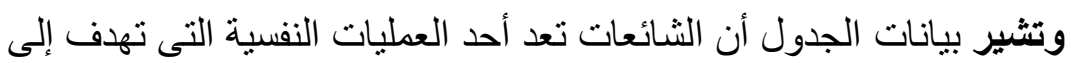

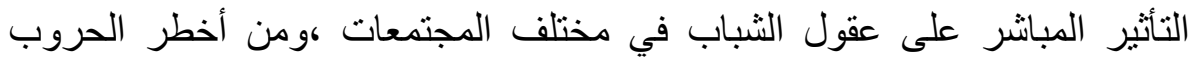
المعنوية التى تتشر في ظل أجواء مشحونة بعواتئل امل اجتماعية واقتصادية وسياسية

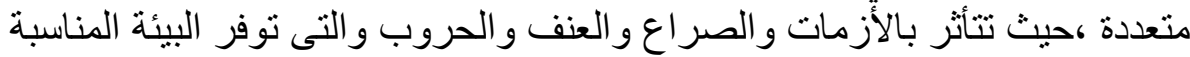

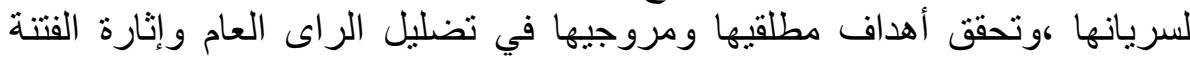

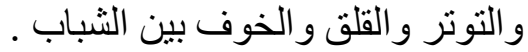

21- دور الثائعات التى تثشر عبر مواقع التواصل الاجتماعي فى إحداث القلق السياسي 


\section{جدول (22)}

يوضح دور الشائعات التى تنشر عبر مواقع التواصل الاجتماعي فى إحداث القلى السياسي بين الثباب التير

\begin{tabular}{|c|c|c|c|c|c|}
\hline \multirow[t]{2}{*}{ الدلالة } & \multirow[t]{2}{*}{ كا2 } & \multirow[t]{2}{*}{ الترتيب } & \multicolumn{2}{|c|}{ ن=إجمالي } & \multirow{2}{*}{ 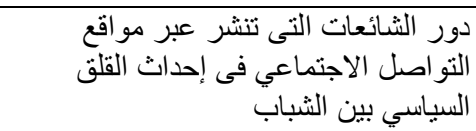 } \\
\hline & & & $\%$ & 5 & \\
\hline د 0.424 دالة غير & 0.640 & 4 & 52 & 208 & الثشباب معلومات مغلوطة ومشوهة لدى \\
\hline 0.001 & 40.960 & 1 & 66 & 264 & خلق نوع من البلبلة فى الأفكار لاى الثباب \\
\hline 0.001 & 16.810 & 2 & 60.3 & 241 & 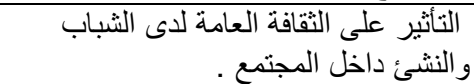 \\
\hline 0.01 & 7.840 & 5 & 43 & 172 & تفكير هم . التُثى نمط تربية الثباب و أساليب \\
\hline 0.001 & 12.960 & 3 & 59 & 236 & 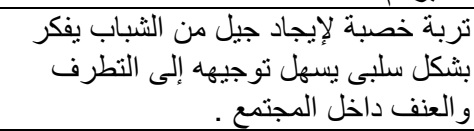 \\
\hline
\end{tabular}

يتضح من الجدول السابق أن نسبة 66\% من أفراد العينة بروا أن الثائعات التى التى

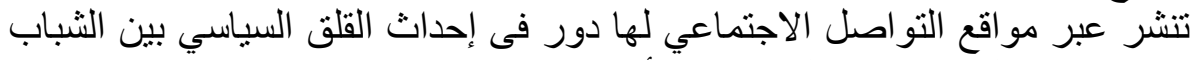

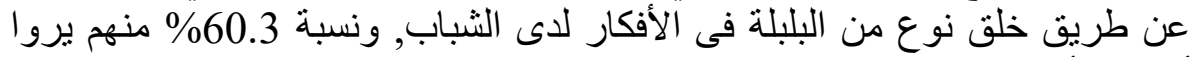

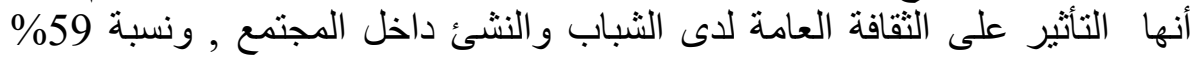

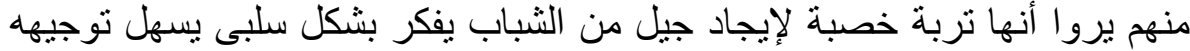

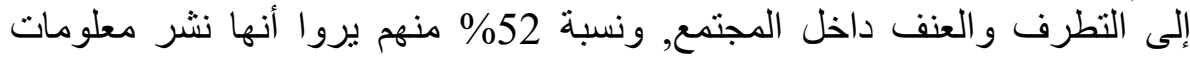
مغلوطة ومشو هة لدى الثباب.

كذلك يتضح وجود فروق ذات دلالة إحصائية بين أفراد العينة في دور الثائعات التى التى التي

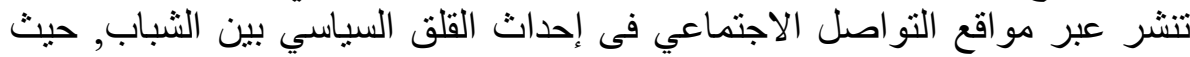

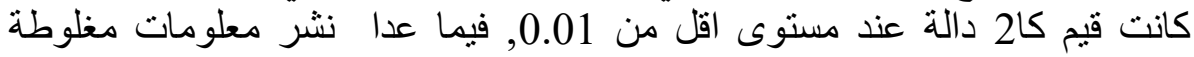
ومشوهة لدى الثباب لم يكن هناك فروق بين افر اد التهن العينة حيث كانت قيم كا2 غير دالة عند مستوى 0.05.

وتثبر بيانات الجدول السابق إلى ارتفاع وعى الثباب و إداركهم لخطورة الثنائعات

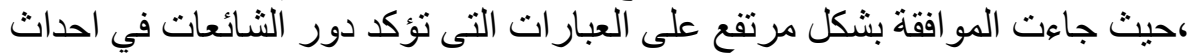

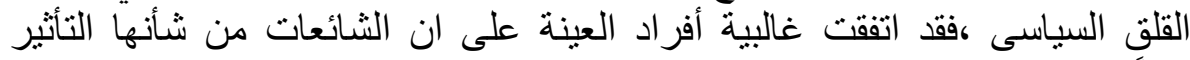

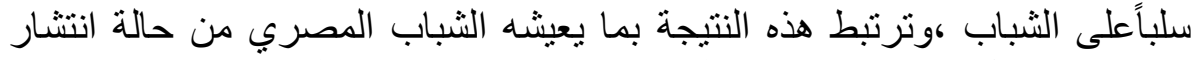

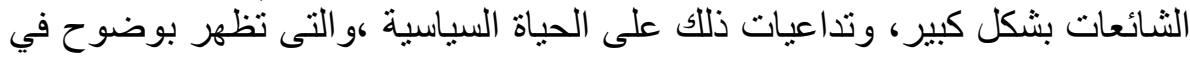

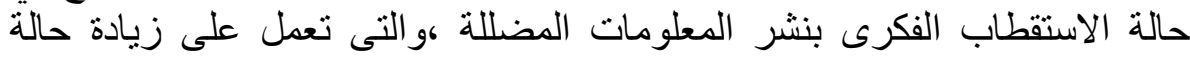

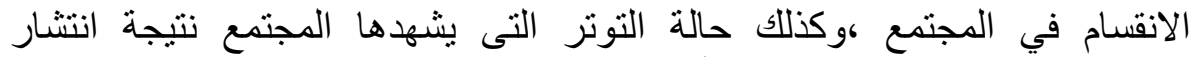

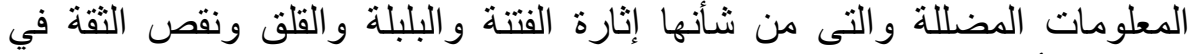

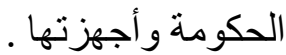


الدحور الرابع : أسباب ظهور وانتثار الثائعات عبر مواقع التواصل الاجتماعي

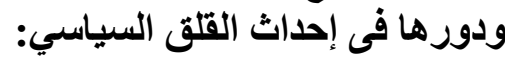
22- أسباب ظهور الثائعات على مواقع التواصل الاجتماعي:

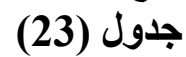

\begin{tabular}{|c|c|c|c|c|c|}
\hline \multirow{3}{*}{ الد الالة } & \multirow[t]{3}{*}{215} & \multirow[t]{3}{*}{ الترتيب } & \multirow{2}{*}{\multicolumn{2}{|c|}{ إجمالي }} & \multirow{3}{*}{ أتوباب الاجتماعي الثائعات على مواقع } \\
\hline & & & & & \\
\hline & & & $\%$ & s & \\
\hline 0.001 & 65.610 & 1 & 70.3 & 281 & ضعف التوثيق \\
\hline 0.001 & 33.640 & 7 & 35.5 & 142 & التشبث بالر أى \\
\hline 0.764 غير دالة & 0.090 & 4 & 49.3 & 197 & إثارة المشكلات \\
\hline 0.05 & 5.290 & 6 & 44.3 & 177 & المخاطرة فى الطرح \\
\hline 0.001 & 57.760 & 2 & 69 & 276 & الكذب و النفاق \\
\hline 0.230 غير دالة & 1.440 & 5 & 47 & 188 & عدم القدرة على التحليل \\
\hline 0.05 & 5.760 & 3 & 56 & 224 & الخروج عن المألوف \\
\hline
\end{tabular}

يتضح من الجدول السابق أن نسبة 70.3\% من أفراد العينة يروا أن أسباب ظهور

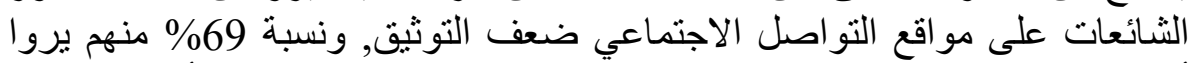

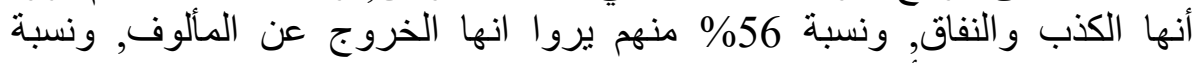

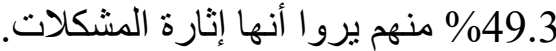
كذللك يتضح وجود فروق ذات دات دلالة إحصائية بين أفراد العينة في أسباب ظهور

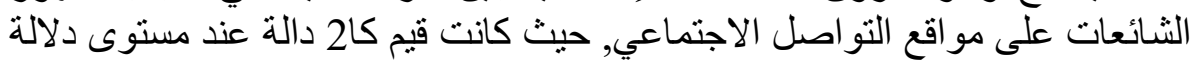

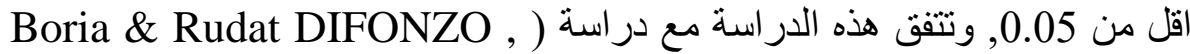

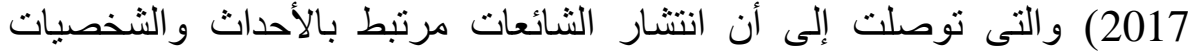

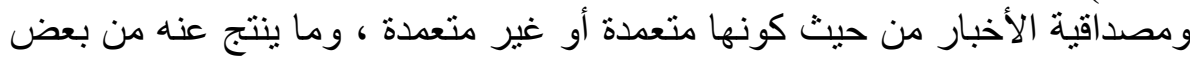

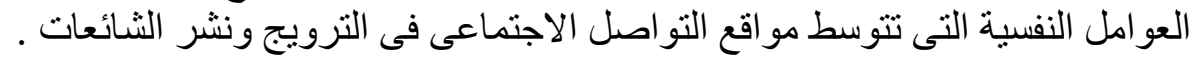
23- المعوقات التنظيمية التى ساعلت على انتثار الثنائعات عبر مواقع التو اصل التل الاجتماعي:

$$
\text { جدول (24) }
$$

يوضح المعوقات التنظيمية التى ساعدت على انتثار الثائعات عبر مواقع التواصل

$$
\text { الاجتماعي ن=400 }
$$

\begin{tabular}{|c|c|c|c|c|c|c|c|c|}
\hline \multirow[t]{2}{*}{ الاتجاه } & \multirow{2}{*}{ المرجح } & \multicolumn{2}{|c|}{ معارض } & \multicolumn{2}{|c|}{ محايد } & \multicolumn{2}{|r|}{ مو افق } & \multirow{2}{*}{ 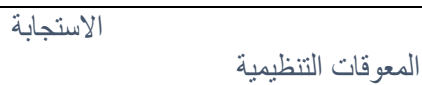 } \\
\hline & & $\%$ & S & $\%$ & ك & $\%$ & S & \\
\hline موافق & 2.74 & 8 & 32 & 10.5 & 42 & 81.5 & 326 & بالأمن المعلوماتى واللوائج والأنظمة الإلكترونية. \\
\hline مو افقى & 2.47 & 10 & 40 & 33.5 & 134 & 56.5 & 226 & 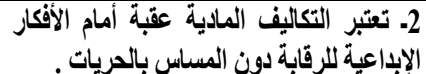 \\
\hline مو افق & 2.72 & 8.8 & 35 & 11 & 44 & 80.3 & 321 & 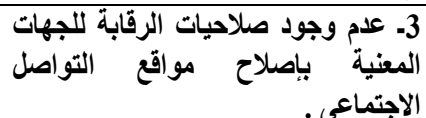 \\
\hline مو افقى & 2.51 & 10.5 & 42 & 28 & 112 & 61.5 & 246 & 4ـ المز ميذائه المن جنوحة . للمراقب لا تتناسب \\
\hline
\end{tabular}




\begin{tabular}{|c|c|c|c|c|c|c|c|c|}
\hline هوافق & 2.74 & 8 & 32 & 10 & 40 & 82 & 328 & 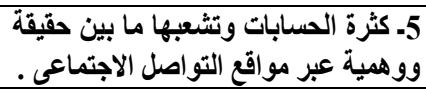 \\
\hline موافق & 2.74 & 8 & 32 & 10 & 40 & 82 & 328 & 6ـــتهافومة التجبيرهور نظم الرقابة وعلام \\
\hline موافق & 2.51 & 9 & 36 & 31 & 124 & 60 & 240 & 7- قلمطلة الاهتمام بتطوير أنظمة الأمن \\
\hline موافقى & 2.72 & 8.3 & 33 & 12 & 48 & 79.8 & 319 & 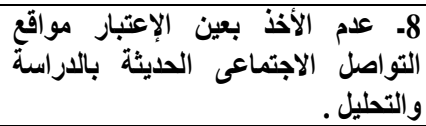 \\
\hline موافقى & 2.53 & 11 & 44 & 25.5 & 102 & 63.5 & 254 & 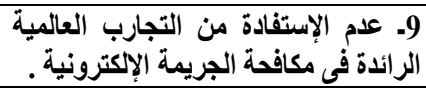 \\
\hline
\end{tabular}

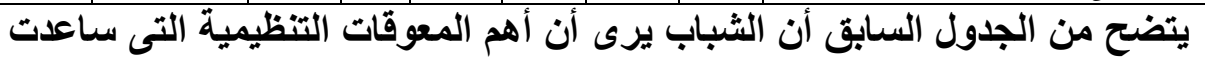

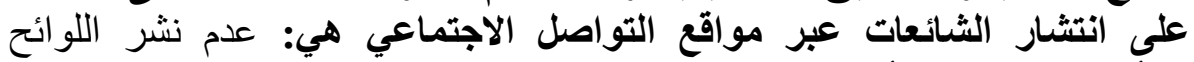

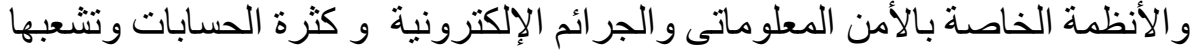

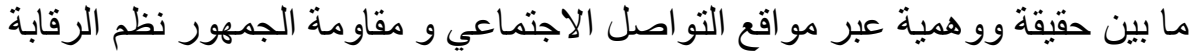

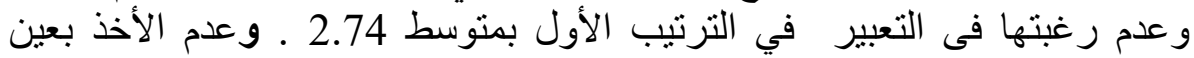

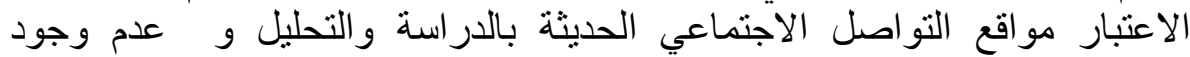
صلاحيات الرقابة للجهات المعنية بإصلاح مواقع التواصلاصل التول الاجتماعي في الترتيب

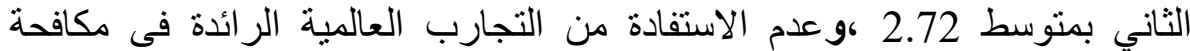

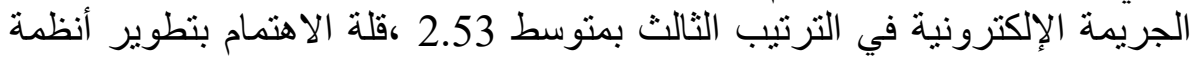

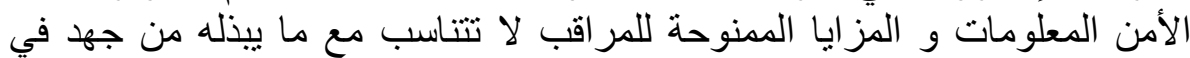
الترتيب الرابع بمتوسط 2.51 ،و تعتبر التكاليف المادية عقبة أمام الأفكار الإبداعية

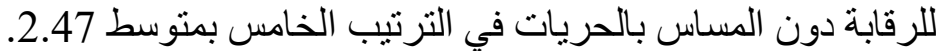

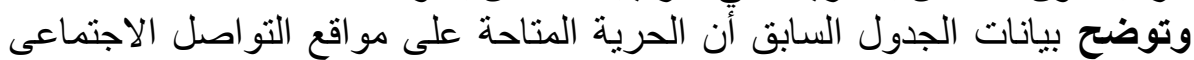

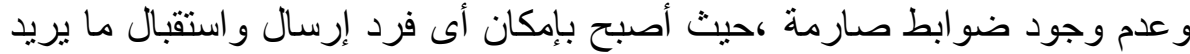

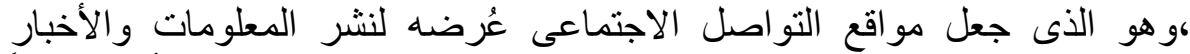

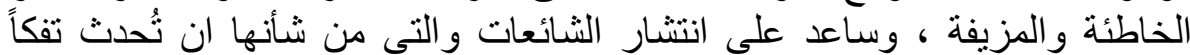

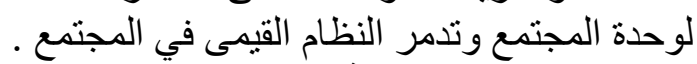

24- المعوقات الشخصية التى ساعدت فئ على انتشار الثائعات عبر مواقع التواصل

جلول (25)

يوضح المعوقات الثخصية التى ساعدت على انتشار الثائعات عبر مواقع التواصل الاجتماعي ن=

\begin{tabular}{|c|c|c|c|c|c|c|c|c|}
\hline \multirow[t]{2}{*}{ الاتجاه } & \multirow{2}{*}{ المرجح المتوسط } & \multicolumn{2}{|c|}{ معارض } & \multicolumn{2}{|r|}{ محايد } & \multicolumn{2}{|r|}{ مو افق } & \multirow{2}{*}{ 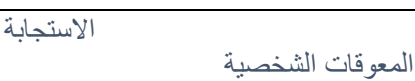 } \\
\hline & & $\%$ & 5 & $\%$ & 5 & $\%$ & s) & \\
\hline مو افق & 2.71 & 8 & 32 & 12.8 & 51 & 79.3 & 317 & 1- التو اصل الاجتماعي . للمشاركة في مواقع \\
\hline مو افق & 2.42 & 8.8 & 35 & 40.3 & 161 & 51 & 204 & 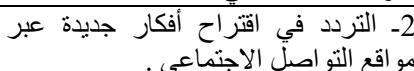 \\
\hline مو افق & 2.60 & 8 & 32 & 24 & 96 & 68 & 272 & 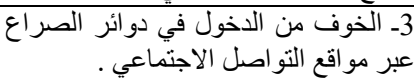 \\
\hline
\end{tabular}




\begin{tabular}{|c|c|c|c|c|c|c|c|c|}
\hline مو افق & 2.45 & 9.8 & 39 & 35.5 & 142 & 54.8 & 219 & 4ـ اقنع التواض اصل مستوى الاجتماعي . الرضا النفسي عن \\
\hline مو افق & 2.64 & 7.3 & 29 & 21.5 & 86 & 71.3 & 285 & 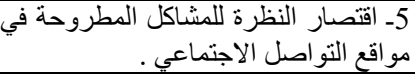 \\
\hline مو افق & 2.42 & 9 & 36 & 40.3 & 161 & 50.8 & 203 & 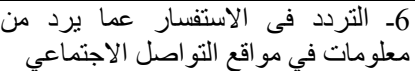 \\
\hline مو افق & 2.65 & 7.3 & 29 & 20.8 & 83 & 72 & 288 & 7- تفضيل الاستمرار و عدم الميل إلى \\
\hline مو افق & 2.44 & 9 & 36 & 38.3 & 153 & 52.8 & 211 & 8- أفر اد المجتم الوازع الديني بالنسبة لبعض \\
\hline مو افق & 2.63 & 8 & 32 & 21.5 & 86 & 70.5 & 282 & 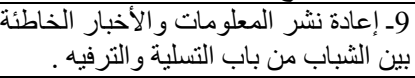 \\
\hline مو افق & 2.46 & 10.3 & 41 & 33.3 & 133 & 56.5 & 226 & بين الأطر افت المختلفة . الاختلال الفكري و الثقافي \\
\hline
\end{tabular}

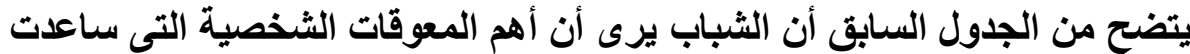

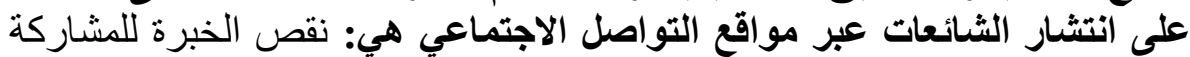

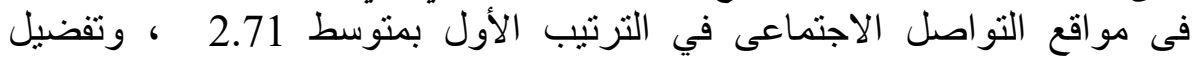

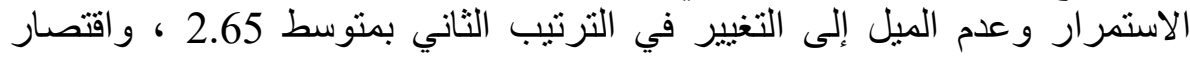
النظرة للمشاكل المطروحة في مواقع التو اصل التيل الاجنماعى في الترتيب التثالث بمتوسط

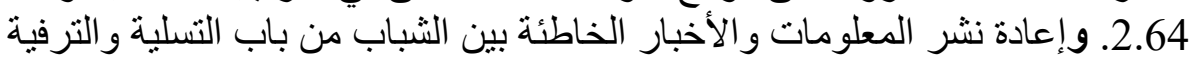

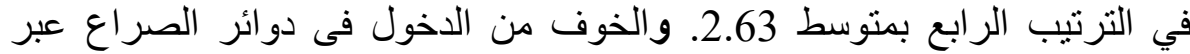
مواقع التو اصل الاجتماعى في الترتيب الخامس بمتوسط 2.60.

ويمكن تفسير ذلك بقلة خبرة مستخدمى مو اقع التو اصل الاجتماعى ،حيث أن النسبة

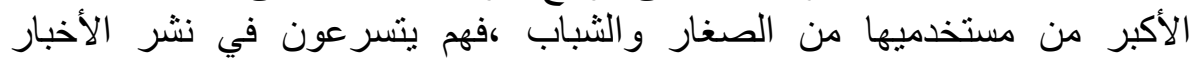

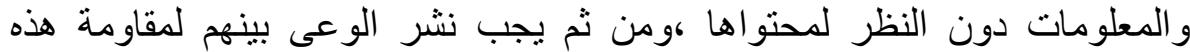

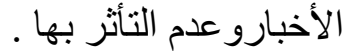

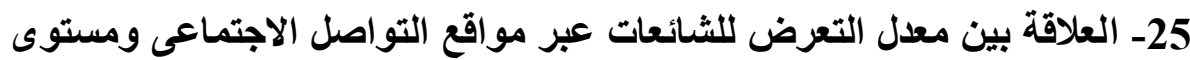
القلث السياسى لدى الثلى معل الثباب:

\section{جدول (26)}

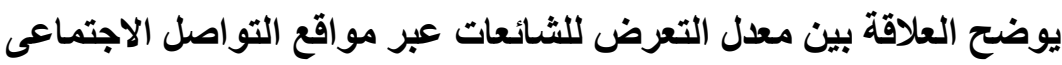
ومستوى القلق السياسى لاى الشباب ن=

\begin{tabular}{|c|c|c|c|c|c|c|c|c|c|c|c|c|c|}
\hline \multirow[t]{2}{*}{ الآجاه } & \multirow{2}{*}{ المرجتج } & \multicolumn{2}{|c|}{ لا تحلث } & \multicolumn{2}{|c|}{ تحثث ناير } & \multicolumn{2}{|c|}{ تحدث أحيانا } & \multicolumn{2}{|c|}{ تحدث غالبا } & \multicolumn{2}{|c|}{ باستمرار } & \multirow{2}{*}{\multicolumn{2}{|c|}{ الأعراض }} \\
\hline & & $\%$ & 5 & $\%$ & 5 & $\%$ & 5 & $\%$ & ك & $\%$ & 3 & & \\
\hline أحيانا & 2.98 & 7.3 & 29 & 11 & 44 & 66.8 & 267 & 6.8 & 27 & 8.3 & 33 & 1 الالثعبر بعضات الجسدية مثل & 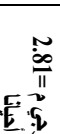 \\
\hline تحلاث & 2.77 & 6.8 & 27 & 31.8 & 127 & 45.5 & 182 & 9.8 & 39 & 6.3 & 25 & 2ـ الاضطر بابتض في النوم & E. \\
\hline
\end{tabular}




\begin{tabular}{|c|c|c|c|c|c|c|c|c|c|c|c|c|c|}
\hline أحيانًا & 2.82 & 7 & 28 & 20.3 & 81 & 62 & 248 & 5.8 & 23 & 5 & 20 & 3- أشعر بفقدان شهيتى & \\
\hline 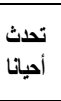 & 2.65 & 9.3 & 37 & 31.3 & 125 & 49.5 & 198 & 5.3 & 21 & 4.8 & 19 & 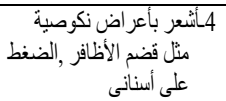 & \\
\hline ت أحياث & 2.86 & 6.3 & 25 & 19.3 & 77 & 63 & 252 & 5.5 & 22 & 6 & 24 & 5ـ فرط فى الحركة . & \\
\hline تحائاث & 2.99 & 7.3 & 29 & 11 & 44 & 65.8 & 263 & 7.5 & 30 & 8.5 & 34 & 1ـ أتوقتم حدوث الأسوأ & $F$ \\
\hline أحيانا & 2.87 & 6.8 & 27 & 29 & 116 & 44.5 & 178 & 9.8 & 39 & 10 & 40 & 2ـ العدبية و الثتوتر الدائم . & $\frac{E}{E}$ \\
\hline أحيانًا & 2.93 & 7 & 28 & 17.5 & 70 & 60 & 240 & 6.3 & 25 & 9.3 & 37 & 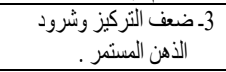 & $\tilde{\dot{\omega}}$ \\
\hline أحياناث & 2.76 & 9 & 36 & 29.3 & 117 & 47.5 & 190 & 5.5 & 22 & 8.8 & 35 & 4ـ التزردد وفقان الثقة بالنفس . & 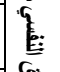 \\
\hline ت أحياثًا & 3.04 & 6 & 24 & 14.3 & 57 & 60.5 & 242 & 8.5 & 34 & 10.8 & 43 & 5ـ الثُعور بالقلث و الاكتئاب . & 䇺 \\
\hline أحيانا & 3.19 & 6 & 24 & 9 & 36 & 57.8 & 231 & 14.8 & 59 & 12.5 & 50 & 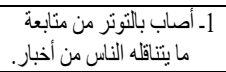 & $E$ \\
\hline أحيانًا & 2.91 & 6.8 & 27 & 29.8 & 119 & 38 & 152 & 16.5 & 66 & 9 & 36 & 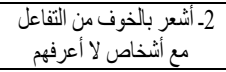 & E. \\
\hline أحيانا ت ت أن & 2.99 & 6.3 & 25 & 17.3 & 69 & 55.3 & 221 & 13.3 & 53 & 8 & 32 & 3ــ الشعور بالوحدة والعزلة . & ii \\
\hline أحيانا ت تحاث & 2.79 & 8.5 & 34 & 28.5 & 114 & 44.8 & 179 & 12.5 & 50 & 5.8 & 23 & 4ـ أفقد مهارتى الاجتماعية . & E \\
\hline أحياناث & 3.08 & 5.5 & 22 & 16.3 & 65 & 54.3 & 217 & 13.3 & 53 & 10.8 & 43 & 5- لا أجد جائوى من التُبير. & 焉 \\
\hline
\end{tabular}

• من 1: 1.8 لا تحدث, ومن 1.81: 2.60 تحدث نادرا, ومن 2.41: 2.61: 3.40 تحدث

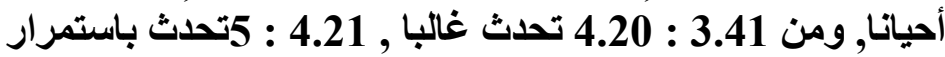

يوضح الجدول السابق رأى عينة الاراسة فى أعراض القلق الفسيولوجي الناتج

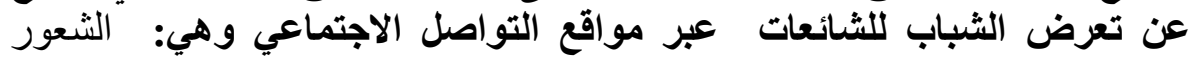

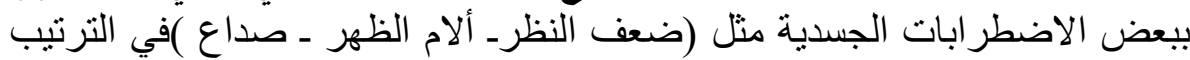

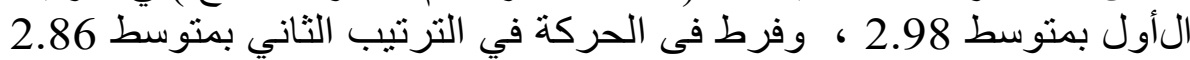
كو أشعر بفقدان شهيتى في الترتيب الثالث بمتوسط

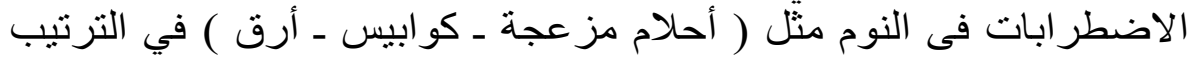

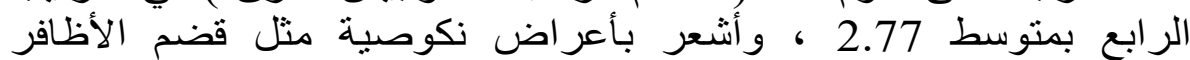
الضغط على أسنانى في الترتيب الخامس بمتوسط 2.65.

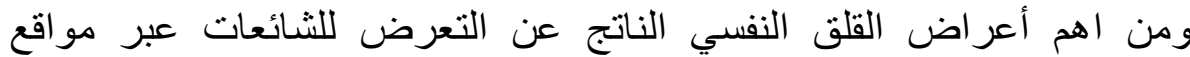
التواصل الاجتماعي هي: الشعور بالقلق والاكتئاب في الترتيب الترني الأول بمتوسط

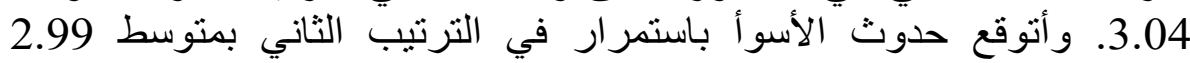
،وضعف التركيز وشرود الذهن المستمر في الترنيب الثالث بمتوسط 2.93

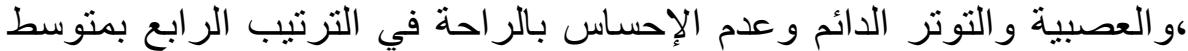

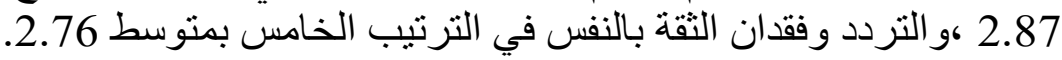




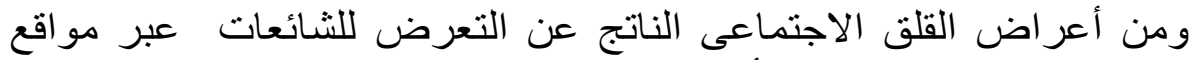

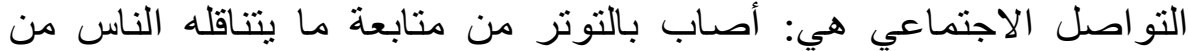
أخبار في الترتيب الأول بمتوسط 3.19 ،ولا لا أجد جدوى من التعبير عن من

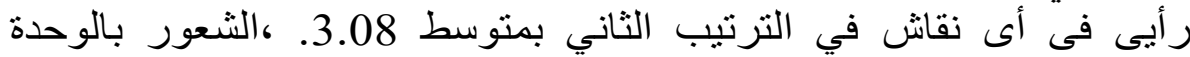

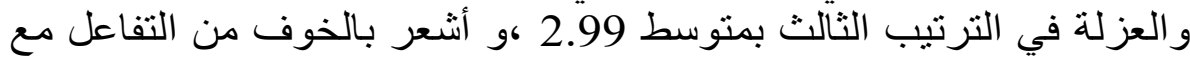
أشخاص لا أعرفهم في الترتيب الرابع بمتوسط 2.91 ، ثم أفقد مهارتى الاجتماعية في الترتيب الخامس بمتوسط ألتر 2.79.

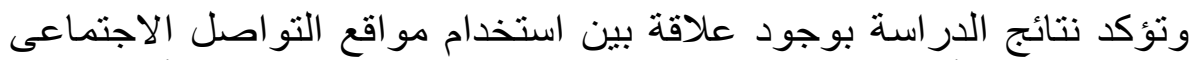

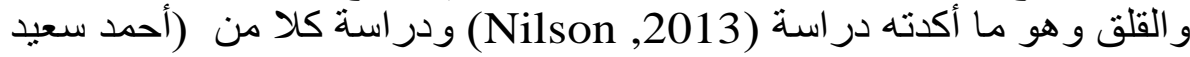

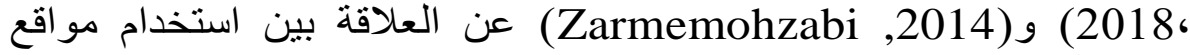
التواصل الاجتماعى ونقص المهارات الاجتماعية و العنف و الصحة النفسية

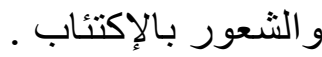

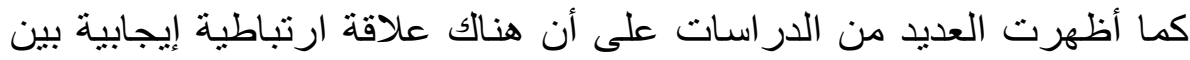

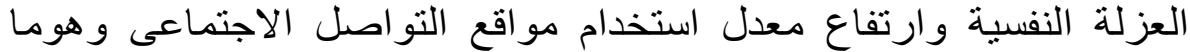

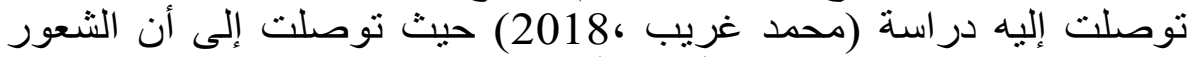

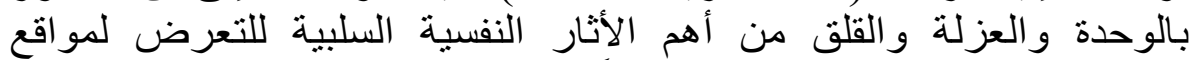

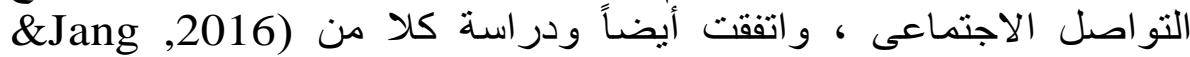
(Lee) و) و (Regmer 2015) وهو أن استخدام مواقع التو اصل الاجتماعى لها

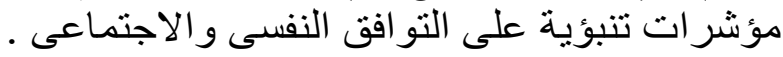
26- أساليب مواجهة الثائعات والقضاء عليها عبر مواقع التواصل الاجتماعى: جدول (27) يوضح أساليب مواجهة الشائعات والقضاء عليها عبر مواقع التواصل الاجتماعن=400

\begin{tabular}{|c|c|c|c|c|c|c|c|c|}
\hline \multirow[t]{2}{*}{ الاتجاه } & \multirow{2}{*}{ المترجط } & \multicolumn{2}{|c|}{ معارض } & \multicolumn{2}{|r|}{ محايد } & \multicolumn{2}{|r|}{ موافق } & \multirow{2}{*}{ الأستاليب } \\
\hline & & $\%$ & ك & $\%$ & 5 & $\%$ & ك & \\
\hline موافق & 2.51 & 9.3 & 37 & 31 & 124 & 59.8 & 239 & و الري التأكد الو اردة صحة الخبر المعلومات و الأخبار \\
\hline موافق & 2.69 & 6.3 & 25 & 18.3 & 73 & 75.5 & 302 & 2ـ السر عة في التى الرد على الثنائعات المنتشرة \\
\hline موافق & 2.48 & 7.8 & 31 & 36.3 & 145 & 56 & 224 & 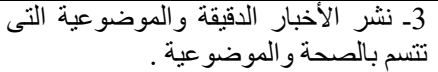 \\
\hline موافق & 2.69 & 6 & 24 & 19.5 & 78 & 74.5 & 298 & 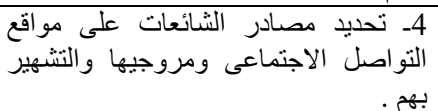 \\
\hline موافق & 2.51 & 8.8 & 35 & 32 & 128 & 59.3 & 237 & 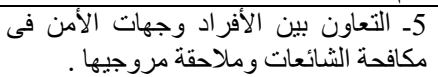 \\
\hline موافق & 2.67 & 6.8 & 27 & 19.5 & 78 & 73.8 & 295 & 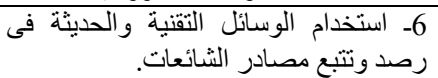 \\
\hline موافق & 2.53 & 6.8 & 27 & 33.3 & 133 & 60 & 240 & 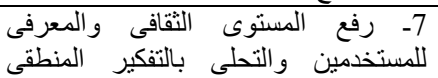 \\
\hline
\end{tabular}




\begin{tabular}{|c|c|c|c|c|c|c|c|c|}
\hline & & & & & & & & و النقدى عند متابعة الخبر \\
\hline موافق & 2.69 & 6.5 & 26 & 18 & 72 & 75.5 & 302 & 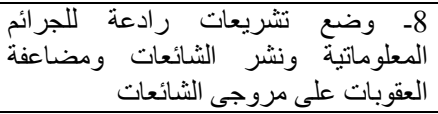 \\
\hline موافق & 2.50 & 7.3 & 29 & 35.3 & 141 & 57.5 & 230 & 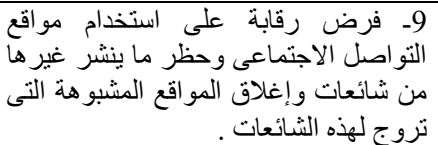 \\
\hline موافق & 2.66 & 8 & 32 & 17.8 & 71 & 74.3 & 279 & 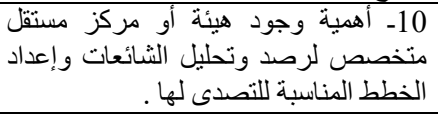 \\
\hline
\end{tabular}

توضح بيانات الجدول السابق رأى عينة الدراسة في أهم أساليب مواجهة الشائعات

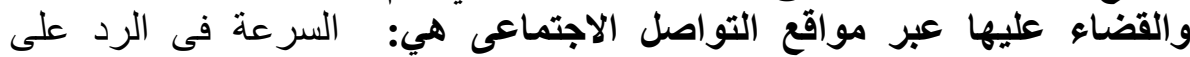

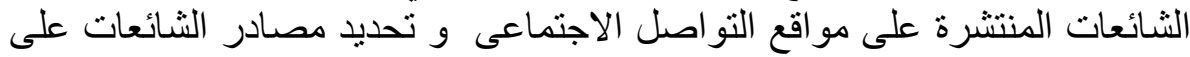

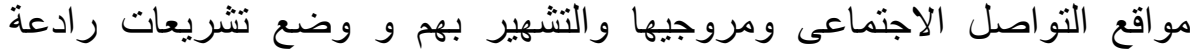

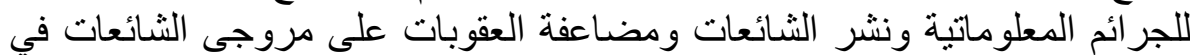

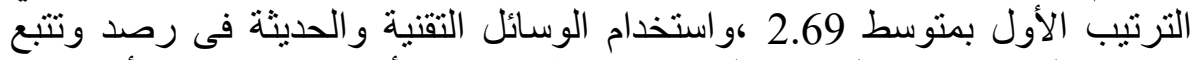

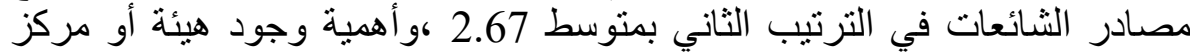

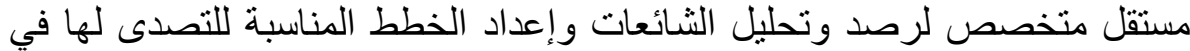
الترتيب الثالث بمتوسط 2.66 ، ورفع المستوى الثقافى والمعرفى للمستخدمين

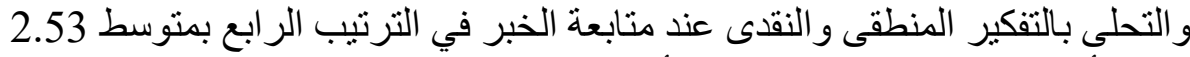

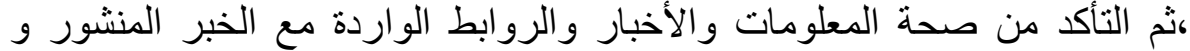

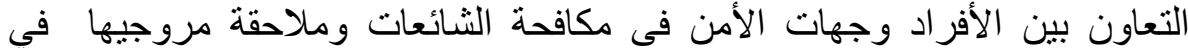
الترتيب الخامس بمتوسط 2.51. ثانياً : اختبارفروض الدراسة :

1- توجد علاقة ذات دلالة إحصائية بين كثافة تعرض الثباب لمواقئ التابل التواصل الاجتماعي وبين كيفية تعامل الشباب مع الأخبار والمعلومات الأبة حول الأحداث الجارية

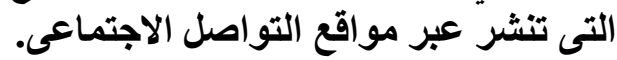

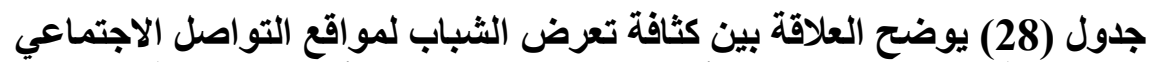

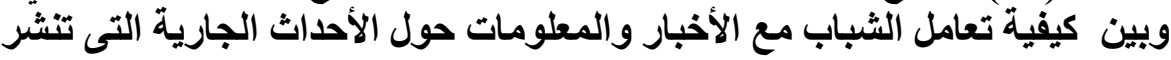
عبر مواقع التواصل الاجتماعى والمعات الاصول

\begin{tabular}{|c|c|c|c|c|c|c|}
\hline الدلالة & القوة & الاتجاه & الارتباط & المعياري الانحر اف & المتوسط & المتغير \\
\hline \multirow[t]{2}{*}{0.01} & \multirow[t]{2}{*}{ ضعيف } & \multirow[t]{2}{*}{ عكسي } & \multirow[t]{2}{*}{$* * 0.192-$} & 1.319 & 7.7 & كثافة ت تعرض التمل الثباب لمواقع \\
\hline & & & & 2.687 & 14.8 & 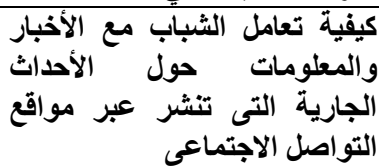 \\
\hline
\end{tabular}




$$
\text { يتضح من الجدول السابق : }
$$

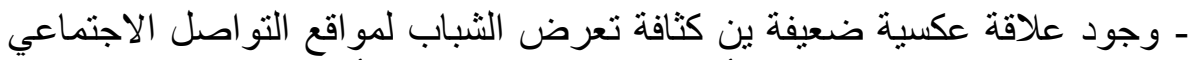

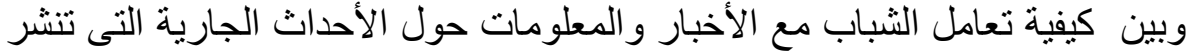

عبر مو اقع التو اصل الاجتماعى, حيث كانت (ر>

$$
\text { ومما سبق ينضح تحقق الفرض الأول كليا. }
$$

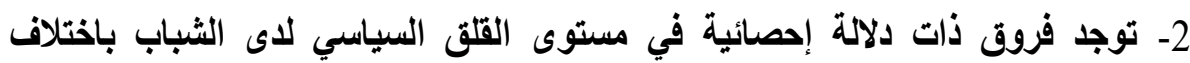
المتغيرات الليموغرافية "( النوع- الإقامة ـ المستوى الاجتماعي- اللسن- التعليم

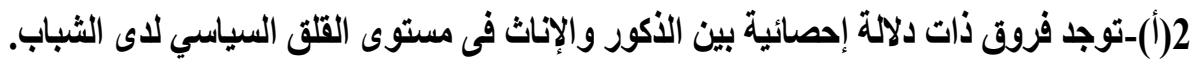

$$
\text { جدول (29) }
$$

\begin{tabular}{|c|c|c|c|c|c|c|}
\hline \multirow{2}{*}{ الد.الالة } & \multirow[t]{2}{*}{ ت } & \multicolumn{2}{|c|}{ إناث (ن=000 } & \multicolumn{2}{|c|}{ ذكور (ن=0200) } & \multirow{2}{*}{ المتنغير } \\
\hline & & $\varepsilon$ & 5 & $\varepsilon$ & 5 & \\
\hline 0.05 & 2.059 & 2.745 & 13.8 & 2.392 & 14.3 & القلق الفسيولوجي \\
\hline 0.001 & 5.593 & 2.745 & 13.8 & 2.868 & 15.4 & القلق النفسي \\
\hline 0.01 & 3.140 & 3.224 & 14.5 & 2.882 & 15.4 & القلق الاجتماعي \\
\hline 0.001 & 3.940 & 8.359 & 42.1 & 7.123 & 45.1 & مستوى القلق السياسي \\
\hline
\end{tabular}

يوضح قيمة (ت)لالالة الفروق بين متوسطي درجات الذكور والإناث في مستوى

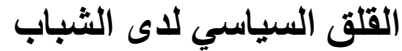

$$
\text { يتضح من الجدول السابق : }
$$

وجود فروق ذات دلالة إحصائية بين منوسطي درجات الذابك الذكور والإناث في

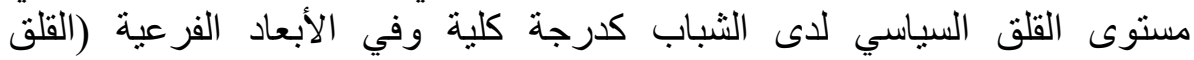

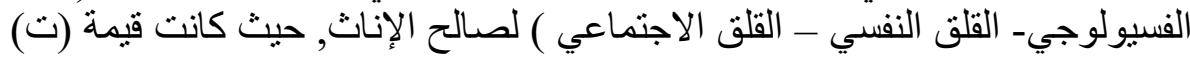
دالة عند مستوى دلالة اقل من 0.05.

2(ب)-توجد فروق ذات دلالة إحصائية بين المقيمين بالريف والمقيمين بالحضر فى مستوى القلق السياسي لاى الثباب.

\begin{tabular}{|c|c|c|c|c|c|c|}
\hline \multirow{2}{*}{ دالدحلالة } & \multirow[t]{2}{*}{$ت$} & \multicolumn{2}{|c|}{ حضر(ن=190) } & \multicolumn{2}{|c|}{ ريف(ن=|210) } & \multirow{2}{*}{ المتغيرة } \\
\hline & & $\varepsilon$ & r & $\varepsilon$ & r & \\
\hline 0.401 غير دالة & $0.840-$ & 2.431 & 14.2 & 2.719 & 13.9 & القلق الفسيولوجي \\
\hline 0.539 غير دالة & $0.615-$ & 2.756 & 14.7 & 3.050 & 14.5 & القلق النفسي \\
\hline 0.638 غير دالة & $0.471-$ & 3.065 & 15.0 & 3.121 & 14.9 & القلق الاجتماعي \\
\hline 0.494 غير دالة & $0.685-$ & 7.651 & 43.9 & 8.139 & 43.4 & مستوى القلق السياسي \\
\hline
\end{tabular}

$$
\text { جلول (30) }
$$

يوضح قيمة (ت) لالالة الفروق بين متوسطي درجات المقيمين بالريف والمقيمين

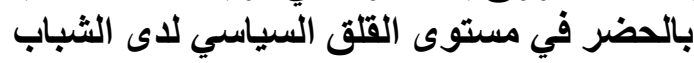


يتضح من الجدول السابق :عدم وجود فروق ذات دلالة إحصائية بين

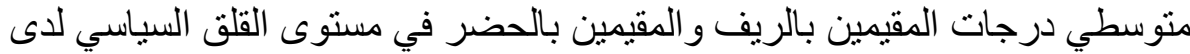
الثباب كدرجة كلية وفي الأبعاد الفرعية (القلق الفسيولوجيـ القلق القئ النفسي - القلق

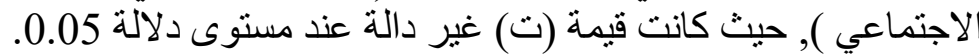

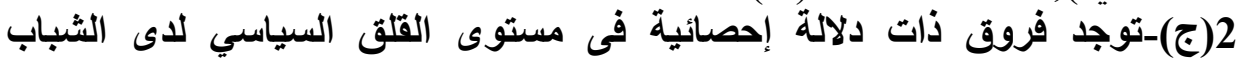
باختلاف المستوى الاجتماعي الاقتصادي.

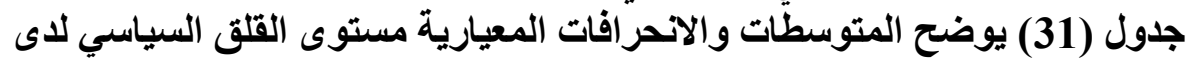

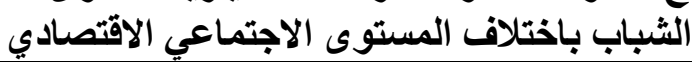

\begin{tabular}{|c|c|c|c|c|}
\hline انحراف & متوسط & $\dot{~ ن}$ & & المستوى الاجتماعي \\
\hline معياري & & & & \multirow{5}{*}{ القلق الفسيولوجي } \\
\hline 2.416 & 14.4 & 96 & منخفض & \\
\hline 2.605 & 14.0 & 218 & متوسط & \\
\hline 2.714 & 13.9 & 86 & مرتفع & \\
\hline 2.585 & 14.1 & 400 & جملة & \\
\hline 2.585 & 14.6 & 96 & منخفض & \multirow[t]{4}{*}{ القلق النفسي } \\
\hline 3.046 & 14.8 & 218 & متوسط & \\
\hline 2.873 & 14.1 & 86 & مرتفع & \\
\hline 2.912 & 14.6 & 400 & جملة & \\
\hline 2.863 & 14.9 & 96 & منخفض & \multirow[t]{4}{*}{ القلق الاجتماعي } \\
\hline 3.149 & 15.1 & 218 & متوسط & \\
\hline 3.193 & 14.6 & 86 & مرتفع & \\
\hline 3.091 & 14.9 & 400 & جملة & \\
\hline 7.641 & 43.9 & 96 & منخفض & \multirow[t]{4}{*}{ مستوى القلق السياسي } \\
\hline 7.902 & 43.9 & 218 & متوسط & \\
\hline 8.204 & 42.6 & 86 & مرتفع & \\
\hline 7.906 & 43.6 & 400 & جملة & \\
\hline
\end{tabular}

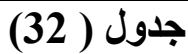

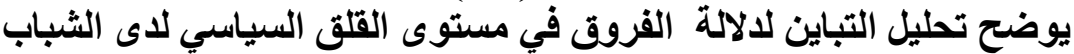

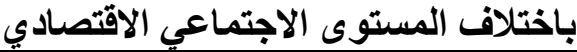

\begin{tabular}{|c|c|c|c|c|c|c|}
\hline الالالة & ف & متوسط & ح.د & مجموع الارجات & البيان & الفروق تبعا إلى \\
\hline \multirow{3}{*}{$\begin{aligned} 0.854 \\
\text { غير دالة }\end{aligned}$} & \multirow[t]{3}{*}{0.934} & 6.243 & 2 & 12.486 & بين مجمو عات & \multirow[t]{3}{*}{ القلق الفسيولوجي } \\
\hline & & 6.684 & 397 & 2653.554 & داخل & \\
\hline & & & 399 & 2666.040 & مجموع & \\
\hline \multirow{3}{*}{ 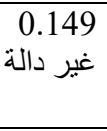 } & \multirow[t]{3}{*}{1.914} & 16.156 & 2 & 32.311 & بين مجمو عات & \multirow[t]{3}{*}{ القلق النفسي } \\
\hline & & 8.439 & 397 & 3350.449 & داخل & \\
\hline & & & 399 & 3382.760 & مجموع & \\
\hline \multirow{3}{*}{ غير دالة } & \multirow[t]{3}{*}{0.814} & 7.784 & 2 & 15.569 & بين مجمو عات & \multirow[t]{3}{*}{ القلق الاجتماعي } \\
\hline & & 9.566 & 397 & 3797.621 & داخل & \\
\hline & & & 399 & 3813.190 & مجموع & \\
\hline \multirow{3}{*}{ 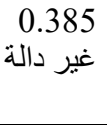 } & \multirow[t]{3}{*}{0.957} & 59.847 & 2 & 119.693 & بين مجمو عات & \multirow{3}{*}{ السياستي } \\
\hline & & 62.516 & 397 & 24819.017 & داخل & \\
\hline & & & 399 & 24938.710 & مجموع & \\
\hline
\end{tabular}




$$
\text { من خلال الجدول السابق يتضح: }
$$

وجود فروق ذات دلالة إحصائية بين متوسطات درجات أفراد العينة

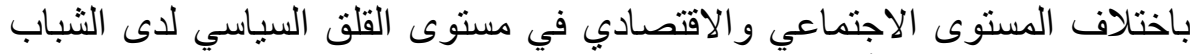

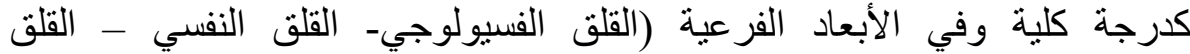
الاجتماعي), حيث كانت قيمة (ف) دالة دالة عند مستوى 0.05.

2(د)-توجد فروق ذات دلالة إحصائية فى مستوى القلق السياسي لاى الثباب باختلاف السن:

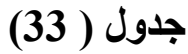

يوضح تحليل التباين لدلالة الفروق في مستوى القلق السياسي لاى الشباب باختلاف السن فينوى

\begin{tabular}{|c|c|c|c|c|c|c|}
\hline الالالة & فت & متوسط & $\tau . \perp$ & الارجموت & البيان & الفروق تبعا إلى \\
\hline \multirow{3}{*}{ غير دالة 0.109} & \multirow[t]{3}{*}{2.224} & 14.772 & 2 & 29.544 & بين مجمو عات & \multirow[t]{3}{*}{ القلقى الفسيولوجي } \\
\hline & & 6.641 & 397 & 2636.496 & داخل & \\
\hline & & & 399 & 2666.040 & مجموع & \\
\hline \multirow{3}{*}{ غير دالة 0.658} & \multirow[t]{3}{*}{0.419} & 3.559 & 2 & 7.117 & بين مجمو عات & \multirow[t]{3}{*}{ القلق النفسي } \\
\hline & & 8.0503 & 397 & 3375.643 & داخل & \\
\hline & & & 399 & 3382.760 & مجموع & \\
\hline \multirow[t]{3}{*}{0.001} & \multirow[t]{3}{*}{6.852} & 63.621 & 2 & 127.243 & بين مجمو عات & \multirow[t]{3}{*}{ القلق الاجتماعي } \\
\hline & & 9.285 & 397 & 3685.947 & داخل & \\
\hline & & & 399 & 3813.190 & مجموع & \\
\hline \multirow{3}{*}{$\begin{array}{r}0.059 \\
\text { غير دالة }\end{array}$} & \multirow[t]{3}{*}{0.2842} & 176.013 & 2 & 352.027 & بين مجمو عات & \multirow{3}{*}{ السيتاسو } \\
\hline & & 61.931 & 397 & 24586.683 & داخل & \\
\hline & & & 399 & 24938.710 & مجموع & \\
\hline
\end{tabular}

من خلال الجدول السابق يتضح:

عدم وجود فروق ذات دلالة إحصائية بين متوسطات درجات أفراد العينة باختلاف السن في مستوى القلق السياسي لدى الدى الثباب كدرجة كلئ كلية وفي الأبعاد

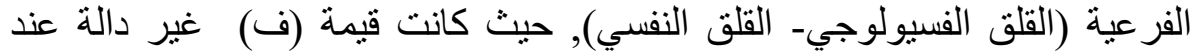
مستوى 0.05, بينما كان بينهم فروق في القلق الاجتماعي لدى الثباب حيث كانت قيم

(ف) دالة عند مستوى 0.001. 


\section{جدول (34)}

يوضح معامل ( LSD ) لمعرفة مصدر التباين المتوسطات والاتحرافات المعيارية مستوى القلق السياسي لاى الثباب باختلاف السن

\begin{tabular}{|c|c|c|c|c|c|c|c|}
\hline أكبر من 30 & من 25 إلى أقل & أقل من 18 إلى 25 & معياري & متوسط & ن & \multicolumn{2}{|c|}{ المستوى الاجتماعي } \\
\hline & & & 2.896 & 13.8 & 119 & أقل من 18 إلى 25 & \multirow{4}{*}{ الفسيولوجي } \\
\hline & & & 2.592 & 14.0 & 174 & أقل من 25 إلى 30 & \\
\hline & & & 2.138 & 14.5 & 107 & أكبر من 30 & \\
\hline & & & 2.585 & 14.1 & 400 & جملة & \\
\hline & & & 3.268 & 14.4 & 119 & أقل من 18 إلى 25 & \multirow{4}{*}{ القلق النفسي } \\
\hline & & & 3.029 & 14.7 & 174 & أقل من 25 إلى 30 & \\
\hline & & & 2.233 & 14.7 & 107 & أكبر من 30 & \\
\hline & & & 2.912 & 14.6 & 400 & جملة & \\
\hline$* 1.4471-$ & $0.3783-$ & & 3.206 & 14.4 & 119 & أقل من 18 إلى 25 & \multirow{4}{*}{ القلق الاجتماعي } \\
\hline \multirow[t]{7}{*}{ *1.0689- } & & & 2.987 & 14.8 & 174 & أقل من 25 إلى 30 & \\
\hline & & & 2.961 & 15.9 & 107 & أكبر من 30 & \\
\hline & & & 3.091 & 14.9 & 400 & جملة & \\
\hline & & & 8.823 & 42.6 & 119 & أقل من 18 إلى 25 & \multirow{4}{*}{ مستوى القلق } \\
\hline & & & 7.909 & 43.4 & 174 & أقل من 25 إلى 30 & \\
\hline & & & 6.572 & 45.0 & 107 & أكبر من 30 & \\
\hline & & & 7.906 & 43.6 & 400 & جملة & \\
\hline
\end{tabular}

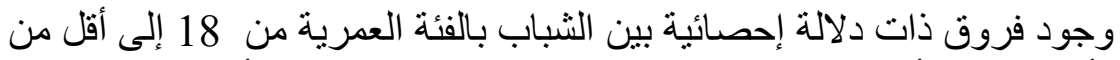

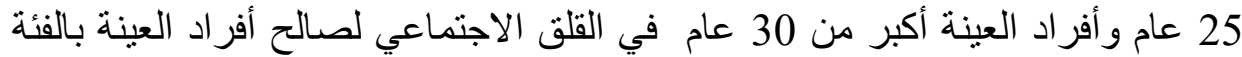

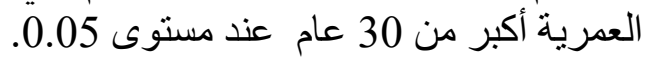




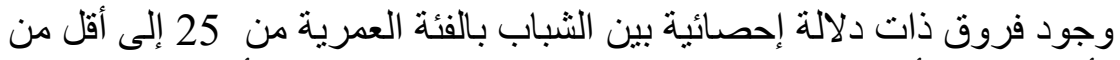

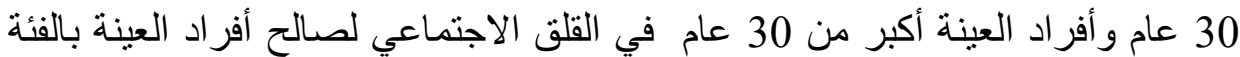

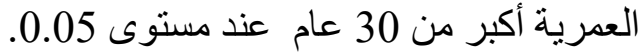

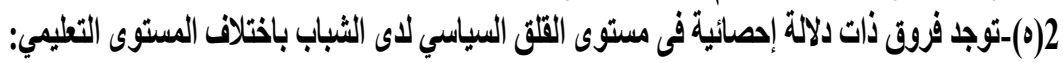

جدول (35)

يوضح المتوسطات والانحر افات المعيارية مستوى القلق السياسي لاى الثباب باختلاف المستوى التعليمي

\begin{tabular}{|c|c|c|c|c|}
\hline انحراف معياري & متوسط & ن & & المستوى التعليمي \\
\hline 2.656 & 14.3 & 88 & دون المتوسط & \multirow{5}{*}{ القلق الفسيولوجي } \\
\hline 2.572 & 13.8 & 107 & متوسط & \\
\hline 2.636 & 14.1 & 185 & جامعي & \\
\hline 1.625 & 14.7 & 20 & دراسات عليا & \\
\hline 2.585 & 14.1 & 400 & جملة & \\
\hline 2.725 & 14.4 & 88 & دون المتوسط & \multirow{5}{*}{ القلق النفسي } \\
\hline 3.024 & 14.4 & 107 & متوسط & \\
\hline 3.039 & 14.8 & 185 & جامعي & \\
\hline 1.625 & 14.7 & 20 & دراسات عليا & \\
\hline 2.912 & 14.6 & 400 & جملة & \\
\hline 2.881 & 14.5 & 88 & دون المتوسط & \multirow{5}{*}{ القلق الاجتماعي } \\
\hline 2.950 & 14.8 & 107 & متوسط & \\
\hline 3.356 & 15.3 & 185 & جامعي & \\
\hline 1.625 & 14.7 & 20 & دراسات عليا & \\
\hline 3.091 & 14.9 & 400 & جملة & \\
\hline 8.203 & 42.1 & 88 & دون المتوسط & \multirow{5}{*}{ مستوى القلق السياسي } \\
\hline 7.466 & 42.9 & 107 & متوسط & \\
\hline 8.282 & 44.2 & 185 & جامعي & \\
\hline 4.876 & 44.1 & 20 & دراسات عليا & \\
\hline 7.906 & 43.6 & 400 & جملة & \\
\hline
\end{tabular}

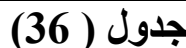

يوضح تحليل التباين لالالة الفروق في مستوى القلق السياسي لاى الثباب باختلاف المستوى التعليمي

\begin{tabular}{|c|c|c|c|c|c|c|}
\hline الدلالة & ف & متوسط & r.د & الارجمات & 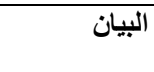 & الفروق تبعا إلى \\
\hline \multirow{3}{*}{ 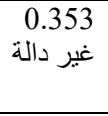 } & \multirow[t]{3}{*}{0.1090} & 7.281 & 3 & 21.843 & بين مجمو عات & \multirow[t]{3}{*}{ القلق الفسيولوجي } \\
\hline & & 6.677 & 396 & 2644.197 & داخل & \\
\hline & & & 399 & 2666.040 & مجموع & \\
\hline \multirow{3}{*}{ 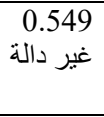 } & \multirow[t]{3}{*}{0.705} & 5.991 & 3 & 17.972 & بين مجمو عات & \multirow[t]{3}{*}{ القلق النفسي } \\
\hline & & 8.497 & 396 & 3364.788 & داخل & \\
\hline & & & 399 & 3382.760 & مجموع & \\
\hline \multirow{3}{*}{ غير دالة 0.192} & \multirow[t]{3}{*}{1.588} & 15.108 & 3 & 45.325 & بين مجمو عات & \multirow[t]{3}{*}{ القلق الاجتماعي } \\
\hline & & 9.515 & 396 & 3767.865 & داخل & \\
\hline & & & 399 & 3813.190 & مجموع & \\
\hline \multirow{3}{*}{$\begin{array}{r}0.544 \\
\text { غير دالة }\end{array}$} & \multirow[t]{3}{*}{0.714} & 44.751 & 3 & 134.253 & بين مجمو عات & \multirow[t]{3}{*}{ مستوى القلق السياسبي } \\
\hline & & 62.638 & 396 & 24804.457 & داخل & \\
\hline & & & 399 & 24938.710 & مجموع & \\
\hline
\end{tabular}




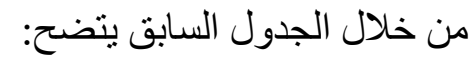

وجود فروق ذات دلالة إحصائية بين متوسطات درجات الفات أفراد العينة

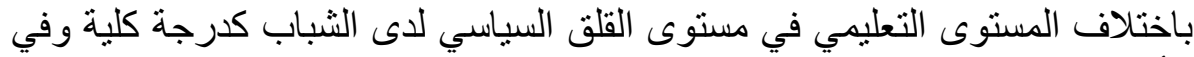

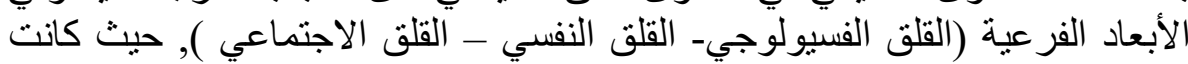

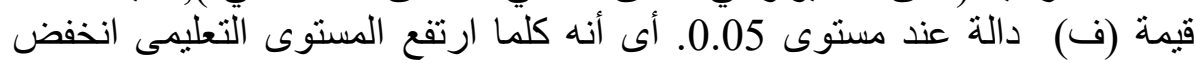
مستوى القلق السياسى لاى الثباب . أي ان الفرض الثاني تحقق جزئياً.

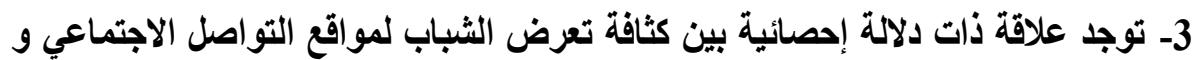
أساليب مواجهة الثائعات والقضاء عليها عبر مواقع التو اصل الاجنتماعي.

جدول (37)

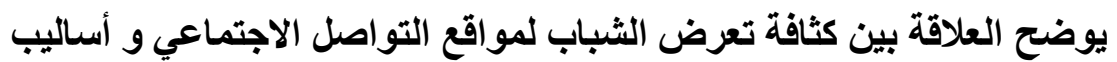

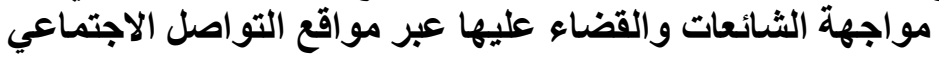

\begin{tabular}{|c|c|c|c|c|c|c|}
\hline الدلالة & القوة & الاتجاه & معامل & المعياري اف الانحر & المتوسط & المتغير \\
\hline \multirow[t]{2}{*}{0.01} & \multirow[t]{2}{*}{ متوسط } & \multirow[t]{2}{*}{ طردي } & \multirow[t]{2}{*}{$* * 0.365$} & 1.319 & 7.7 & التثافة ت تعرضل الاجتماعباب لمواقع \\
\hline & & & & 4.744 & 25.9 & 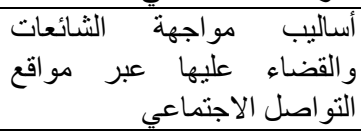 \\
\hline
\end{tabular}

يتضح من الجدول السابق : وجود علاقة طردية متوسطة بين كثافة تعرض الثباب الثباب

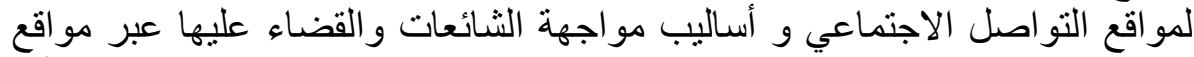

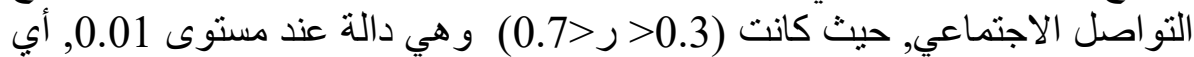

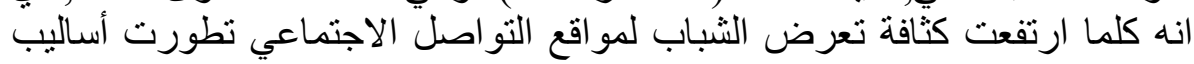
مو اجهتهم الثنائعات و القضاء عليها عبر مو اقع التواصل الاجتماعي. أي ان الفرض الثالث لم يتحقى كلياً.

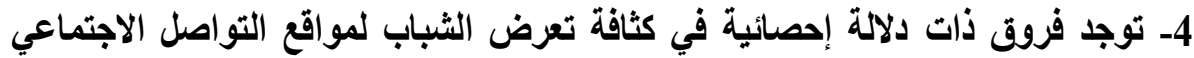

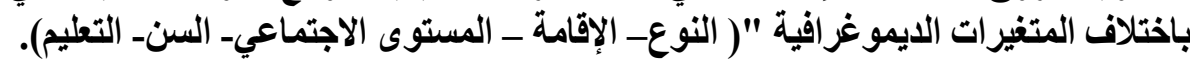

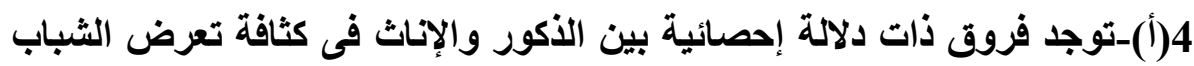

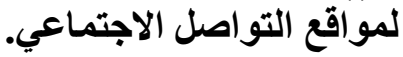


جدول (38) (38)

يوضح قيمة (ت) لالالة الفروق بين متوسطي درجات الذكور والإناث في كثافة تعرض الثباب لمواقع التواصل الاجتماعي

\begin{tabular}{|c|c|c|c|c|c|c|}
\hline \multirow{2}{*}{ الد.2398 } & \multirow[t]{2}{*}{$ت$} & \multicolumn{2}{|c|}{ إناث(ن=1200) } & \multicolumn{2}{|c|}{ ذكور(ن=0200) } & \multirow{2}{*}{ المتغير } \\
\hline & & $\varepsilon$ & 5 & $\varepsilon$ & م & \\
\hline 0.001 & 4.995 & 1.24 & 7.4 & 1.318 & 8.0 & 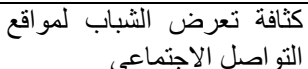 \\
\hline
\end{tabular}

يتضح من الجدول السابق : وجود فروق ذات دلالة إحصائية بين متوسطي لإباءي

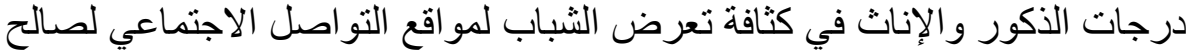
الذكور, حيث كانت قيمة (ت) دالة عند مستوى دلالة

4(ب)-توجد فروق ذات دلالة إحصائية بين المقيمين بالريف والمقيمين بالحضر فى دلى

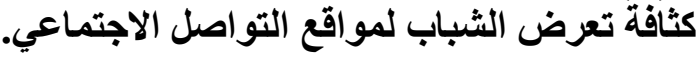
جلول (39)

يوضح قيمة (ت)لالالة الفروق بين متوسطي درجات المقيمين بالريف والمقيمين بالحضر في كثافة تعرض الثباب لمواقع التواصل التل الاجتماعي

\begin{tabular}{|c|c|c|c|c|c|c|}
\hline اللالالة & $ت$ & (19) & & & ريف(ن) & الإقامة \\
\hline د.2398 & & $\varepsilon$ & ? & $\varepsilon$ & ? & المتغير \\
\hline 0.01 & 3.139 & 1.220 & 75 & 1.377 & 7.9 & التوافة تعرض الاجتماعي الثباب لمواقع \\
\hline
\end{tabular}

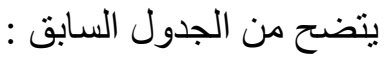

وجود فروق ذات دلالة إحصائية بين متوسطي درجات الكئل المقيمين بالريف

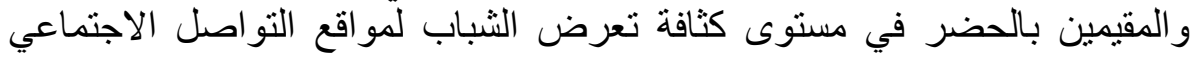

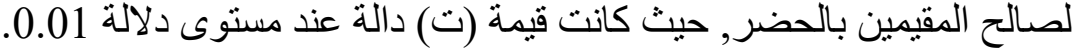

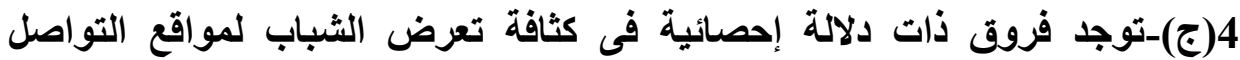
الاجتماعي باختلاف المستوى الاجتماعي الاقتصادي.

$$
\text { جدول (40) }
$$

يوضح تحليل التباين لالالة الفروق في كثافة تعرض الثباب لمواقع التواصل

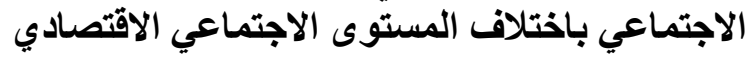

\begin{tabular}{|c|c|c|c|c|c|c|}
\hline الدلالة & ف & متوسط & r.د & مجموع & البيان & الفروق تبعا إلى \\
\hline \multirow[t]{3}{*}{0.001} & \multirow{3}{*}{18.776} & 30.002 & 2 & 60.004 & بين مجمو عات & \multirow{3}{*}{ 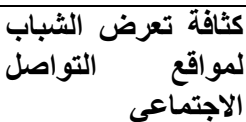 } \\
\hline & & 1.598 & 397 & 634.356 & داخل & \\
\hline & & & 399 & 694.360 & مجموع & \\
\hline
\end{tabular}




$$
\text { من خلال الجدول السابق يتضح: }
$$

وجود فروق ذات دلالة إحصائية بين متوسطات درجات أفراد العينة باختلاف المستوى الاجتماعي الاقتصادي في كثافة تعرض الثاعة الثباب لمو اقع التو اصل الاجتماعي, حيث كانت قيمة (ف) دالة الة عند مستوى 0.001.

$$
\text { جدول (41) }
$$

يوضح معامل ( LSD ) لمعرفة مصدر التباين المتوسطات والانحر افات المعيارية كثافة

\begin{tabular}{|c|c|c|c|c|c|c|c|}
\hline مرتفع & متوسط & منذفض & معبار اف & متوسط & ن & \multicolumn{2}{|r|}{ المستوى الاجتماعي } \\
\hline *0.8978- & $* 0.9104-$ & & 1.542 & 7.0 & 96 & منخفض & تعرض \\
\hline 0.0126 & & & 1.241 & 7.9 & 218 & متوسط & لمواقع ل ل ل ل \\
\hline & & & 0936 & 7.9 & 86 & مرتفع & التواصل الاجتماعي \\
\hline & & & 1.319 & 7.7 & 400 & جملة & \\
\hline
\end{tabular}
تعرض الثباب لمواقع التواصل الاجتماعي باختلاف المستوى الاجتماعي الاقتصادي

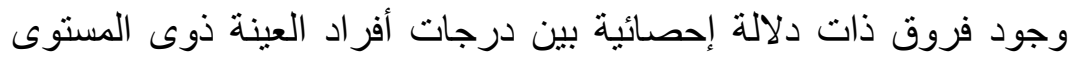

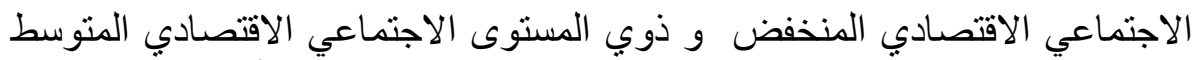

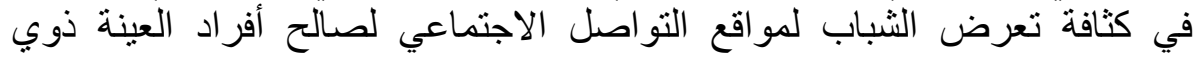

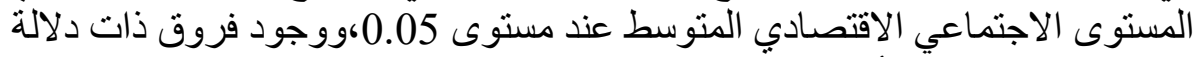

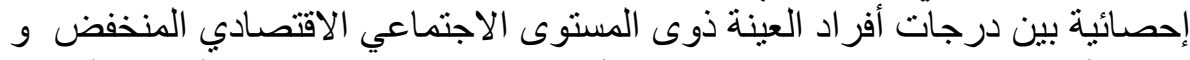

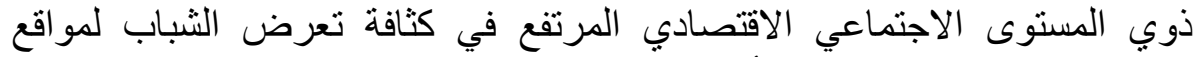

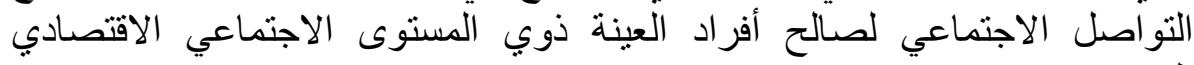

$$
\text { المرتفع عند مستوى } 0.05 \text { الاجنمي }
$$

4(د)-توجد فروق ذات دلالة إحصائية فى كثافة تعرض الثباب لمواقع التواصل

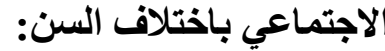

$$
\text { جدول (42) }
$$

\begin{tabular}{|c|c|c|c|c|}
\hline انحياري & متوسط & $\dot{ن}$ & & المستوى الاجتماعي \\
\hline 1.190 & 7.7 & 119 & من 18 إلى أقّل من 25 عام & \multirow{4}{*}{ كثافة تعرض الثباب لمواقع الاجن } \\
\hline 1.368 & 7.8 & 174 & من 25 إلى أقّل من 30 عام & \\
\hline 1.382 & 7.6 & 107 & أكبر من 30 عام & \\
\hline 1.319 & 7.7 & 400 & جملة & \\
\hline
\end{tabular}

يوضح المتوسطات والانحرافات المعيارية كثافة تعرض الشباب لمواقع التواصل

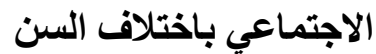




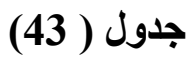

يوضح تحليل التباين لدلالة الفروق في كثافة تعرض الثباب لمواقع التواصل الاجتماعي باختلاف السن فئن

\begin{tabular}{|c|c|c|c|c|c|c|}
\hline الدلالة & ف & متوسط & r.د & الأرجوت & البيان & الفروق تبعا إلى \\
\hline \multirow{3}{*}{ غير دالة } & \multirow[t]{3}{*}{0.253} & 0.442 & 2 & 0.884 & بين مجمو عات & \multirow{3}{*}{ كثوافة تعرض الثقاصن } \\
\hline & & 1.747 & 397 & 693.476 & داخل & \\
\hline & & & 399 & 694.360 & مجموع & \\
\hline
\end{tabular}

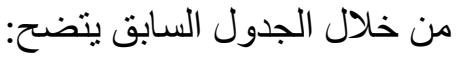

عدم وجود فروق ذات دلالة إحصائية بين منوسطات درجات الإن أفراد العينة

باختلاف السن في كثافة تعرض الثباب لمو اقع التواصل التر الاجتماعي, حيث كانت قيمة

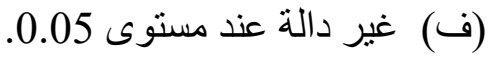

4(0)-توجد فروق ذات دلالة إحصائية فى كثافة تعرض الثباب لمواقع التواصل الاجتماعي باختلاف المستوى التعليمي:

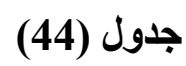

يوضح المتوسطات والانحرافات المعيارية كثافة تعرض الثباب لمواقع التواصل الاجتماعي باختلاف المستوى التعليمي

\begin{tabular}{|c|c|c|c|c|}
\hline انحراف & متوسط & ن & \multirow{2}{*}{\multicolumn{2}{|c|}{ المستوى التعليمي }} \\
\hline معياري & & & & \\
\hline 1.371 & 7.6 & 88 & دون المتوسط & \multirow{5}{*}{ التثاصة تعرض الاجتماعي الثباب لمواقع } \\
\hline 1.156 & 7.8 & 107 & متوسط & \\
\hline 1.397 & 7.8 & 185 & جامعي & \\
\hline 1.191 & 7.9 & 20 & دراسات عليا & \\
\hline 1.319 & 7.7 & 400 & جملة & \\
\hline
\end{tabular}

جلول (45) (45)

يوضح تحليل التباين لالالة الفروق في كثافة تعرض الثباب لمواقع التواصل الاجتماعي باختلاف المستوى التطليمي

\begin{tabular}{|c|c|c|c|c|c|c|}
\hline الالالة & ف & متوسط & ح.د & الدرجوات & البيان & الفروق تبعا إلى \\
\hline \multirow{3}{*}{ غير دالة 0.582} & \multirow[t]{3}{*}{0.651} & 1.137 & 3 & 3.410 & بين را. & \multirow{3}{*}{ 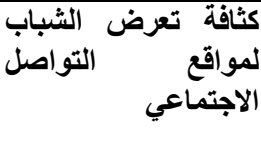 } \\
\hline & & 1.745 & 396 & 690.950 & داخل & \\
\hline & & & 399 & 694.360 & مجموع & \\
\hline
\end{tabular}

من خلال الجدول السابق بتضح: 
عدم وجود فروق ذات دلالة إحصائية بين منوسطات درجات أفراد العينة

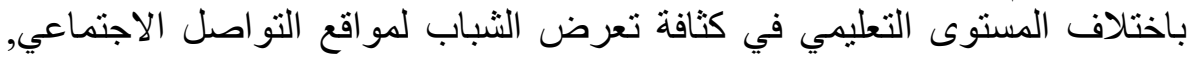

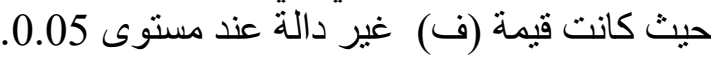
أي ان الفرض الرابع تحقق جزئياً.

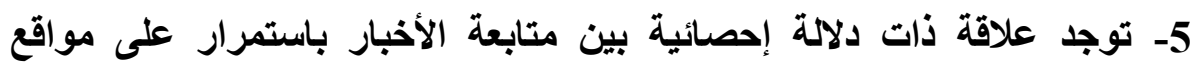

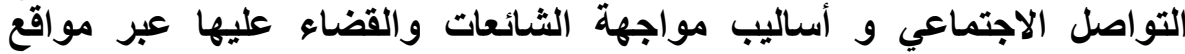

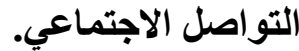
جدول (46) يوضح العلاقة بين كثافة تعرض الثباب لمواقع التواصل الاجتماعي و

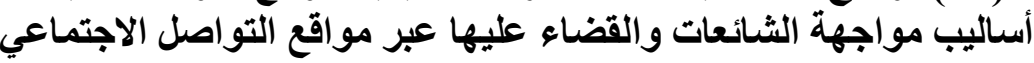

\begin{tabular}{|c|c|c|c|c|c|c|}
\hline مستوى & القوة & الاتجاه & معامل & الالمعياري اف & المتوسط & المتغير \\
\hline \multirow[t]{2}{*}{0.01} & \multirow[t]{2}{*}{ متوسط } & \multirow[t]{2}{*}{ طردي } & \multirow[t]{2}{*}{$* * 0.654$} & 0.575 & 2.3 & 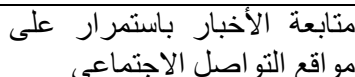 \\
\hline & & & & 4.744 & 25.9 & 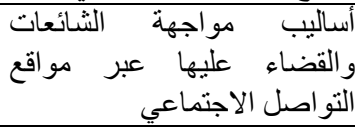 \\
\hline
\end{tabular}

$$
\text { يتضح من الجدول السابق : }
$$

- وجود علاقة طردية منوسطة بين متابعة الأخبار باستمر ار على مواقع التواصل

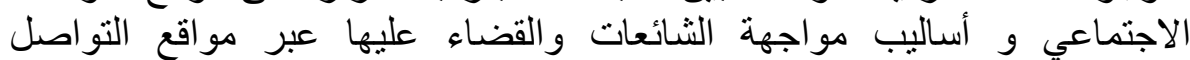

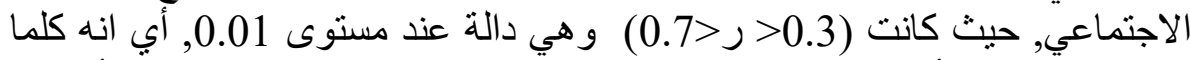

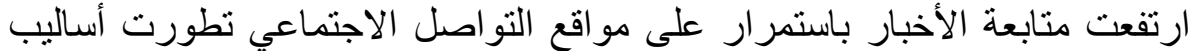

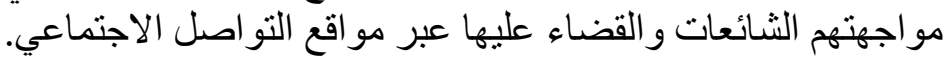
أي ان الفرض الخامس لم تحقق كلياً.

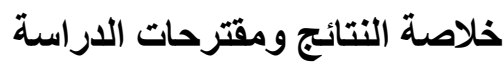
أولاً: خلاصة النتائج :-

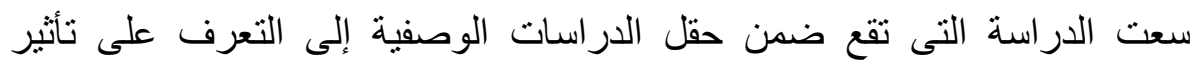

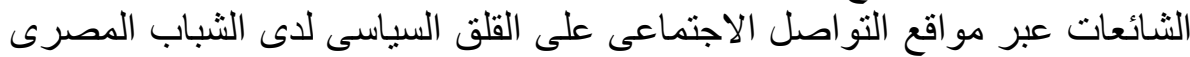

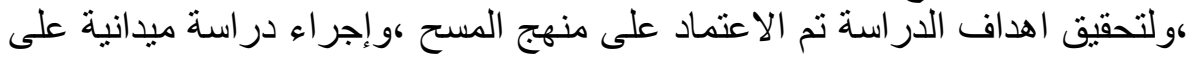

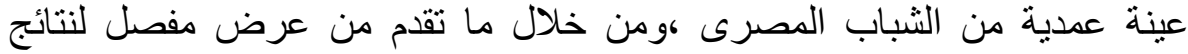
الدر اسة امكن استخلاص عدة مؤشر ات وهى :

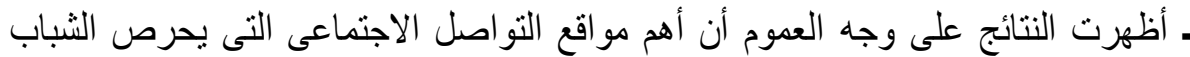

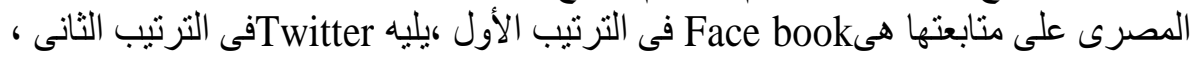
ثم Instagram فى الترتيب الثالث ، ثم Sinap chat في الترتيب الر ابع ـ التئ 


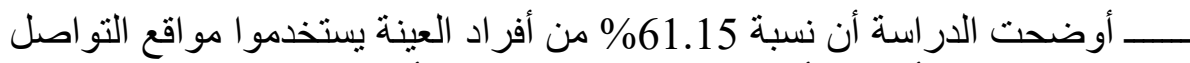

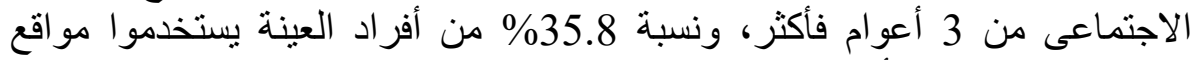

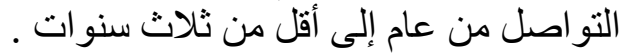

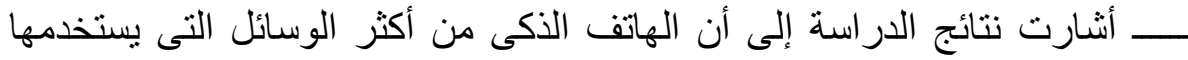

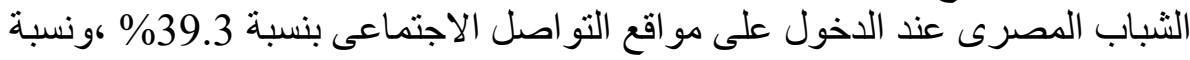

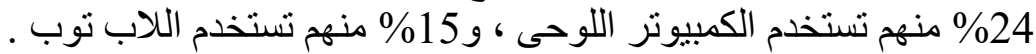

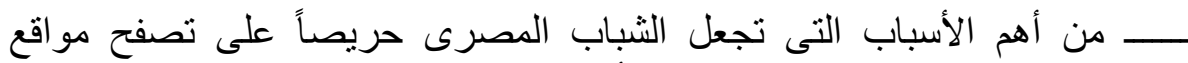

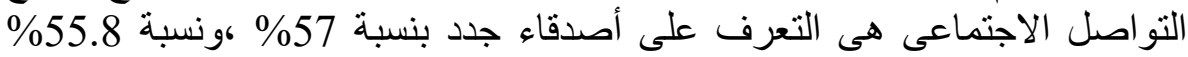
منهم تفضل نشر الصور ومقاطع الفيديو ،ونسبة 52.8\% تفضل متابعة الأخبار

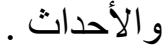

ــــ من أهم الأنثطة التى يقوم بها الثنباب على مواقع التواصل الاجتماعى هى والثى

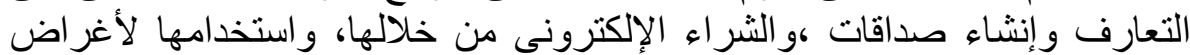

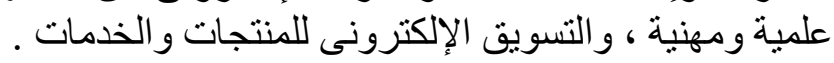

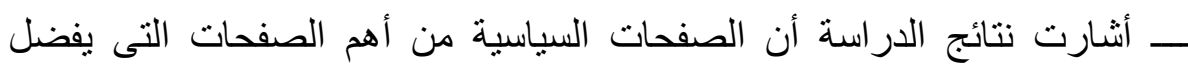

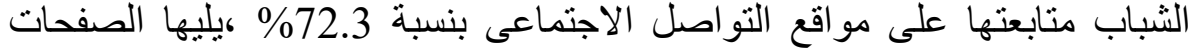
الرياضية بنسبة 63.2\% ،يليها الصفحات الاقتصادية والثقافية .

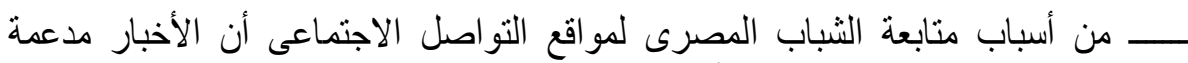

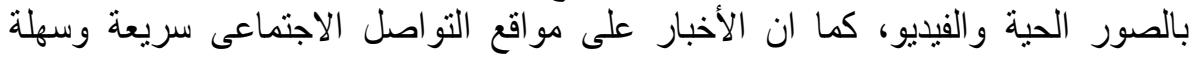
الإنتشار . المرن

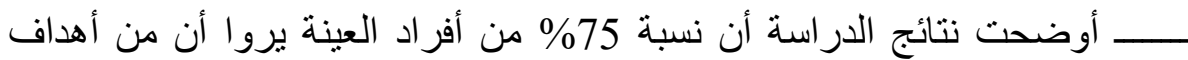

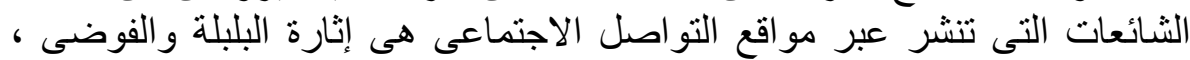

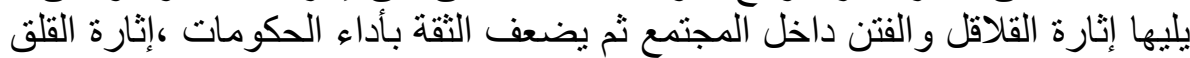

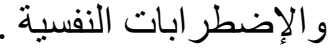

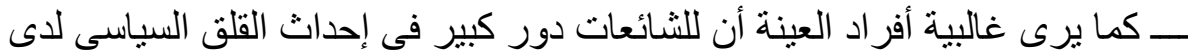

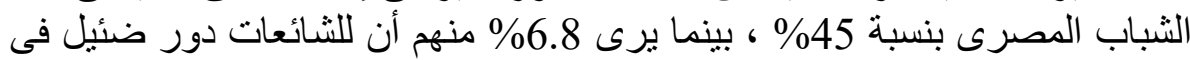
إحداث القلق السياسى لدى الثنباب المصرى . لئرى

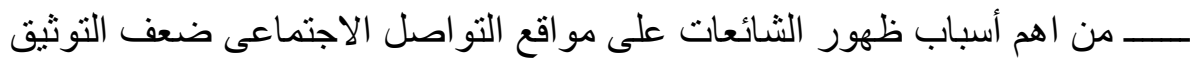

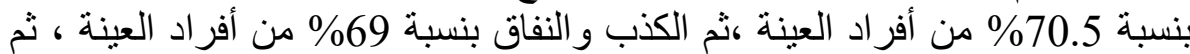
الخروج عن المألوف بنسبة 59\% ثم إثارة المشكلات .

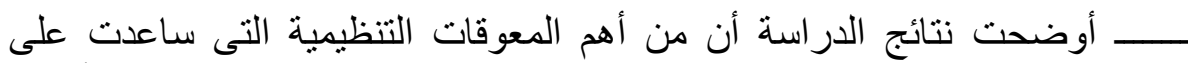

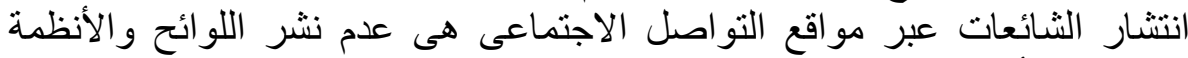
الخاصة بالأمن المعلوماتى والجرائم الإلكترونية ،وكثرة الحسابات هُ وتثعبرها ما بين 


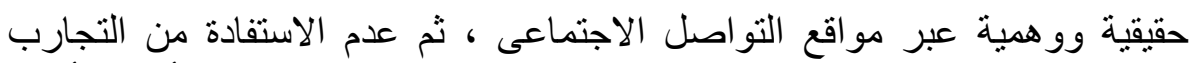
العالمية الرائدة فى مكافحة الجريمة ، و التكاليف المادية تثق عقبة المائة المام الأفكار

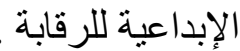

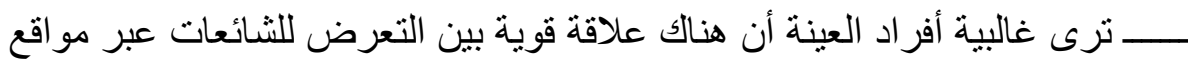

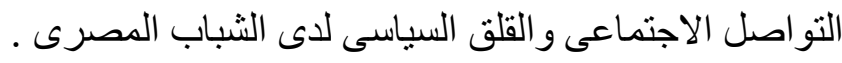

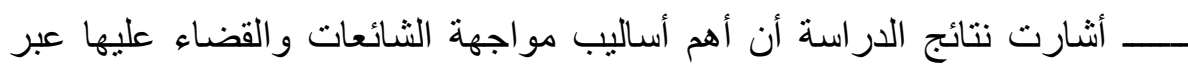

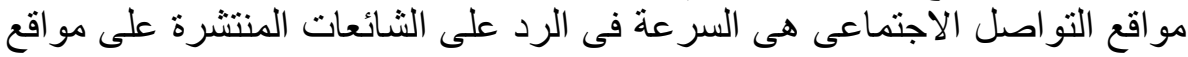

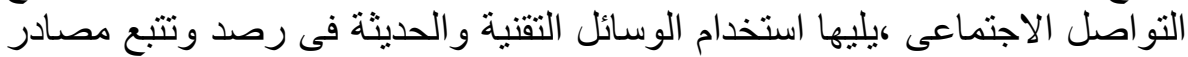

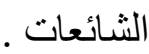

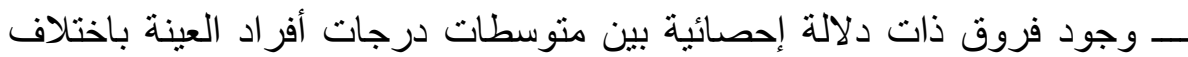

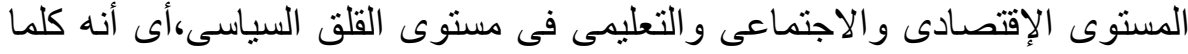

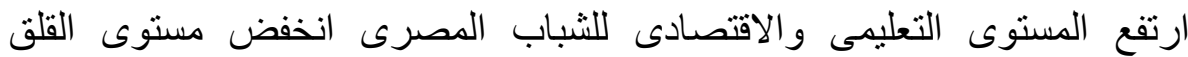

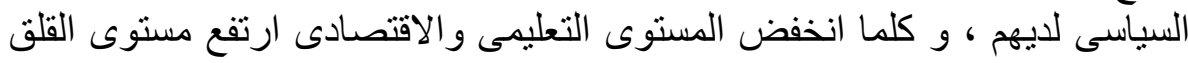

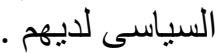

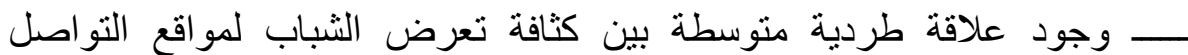
الاجتماعى وأساليب مواجهة الثنائعات و القضاء عناء عليها عبر مواقع التواصل لتصل

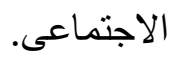

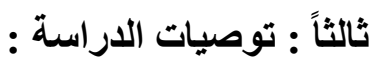

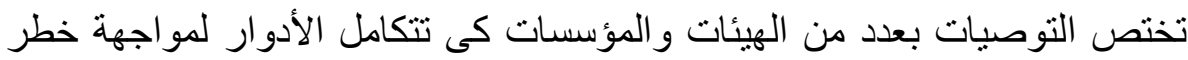
الثائعات و الحد من تأثثير اتها على الأمن القومى و السلام الاجتماعى فيما يلى : لألى الادئ

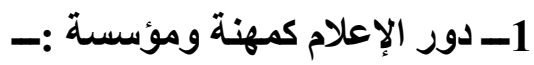

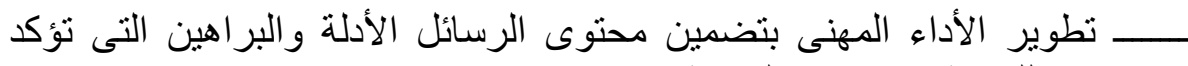
مصداقيتها للتفرقة بينها وبين الثنائعة .

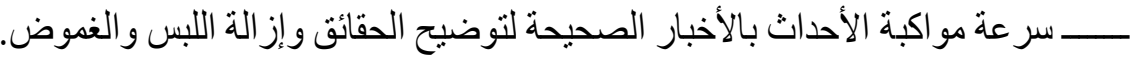

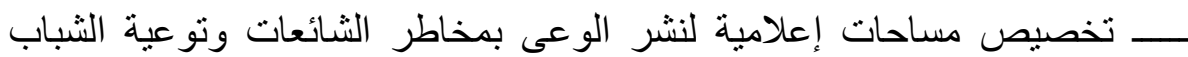

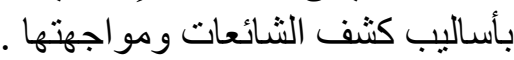

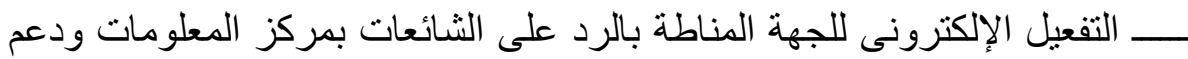

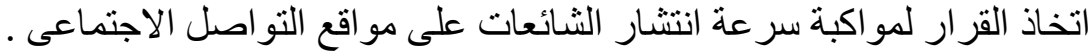
2-20 دور المؤسسات التربوية والتعليمية :

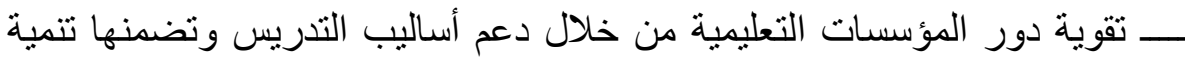

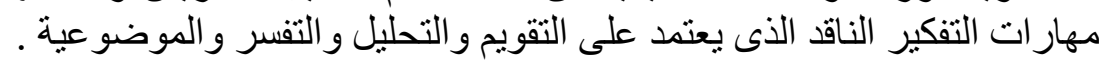



الأزمات . ـــــتمية روح المسئولية الاجتماعية كى يقوم الثباب بحماية المجتمع من الثـائعات و عدم نشر ها .

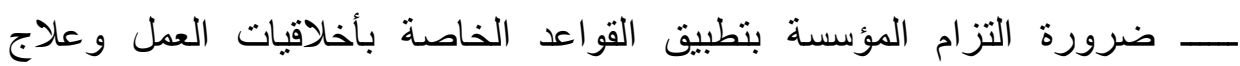
السلوكيات السلبية للعاملين كتسريب المعلومات ونشئ ولثر الثائعات . 3- دور المؤسسة الدينية :

ـــــأهيل رجال الدين وعقد الدورات التدريبية لهم لتوعيتهم بشأن الثائعات وكيفية معالجتها .

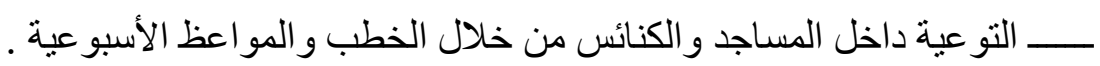

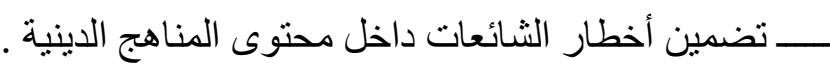

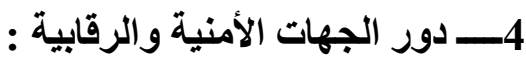

- ــــ وضع تشريعات وقو انين تتضمن عقوبات و اضحة وصـارمة لتجريم ترويج الثـائعات على مو اقع التو اصل الاجتماعى. وقوانئ.

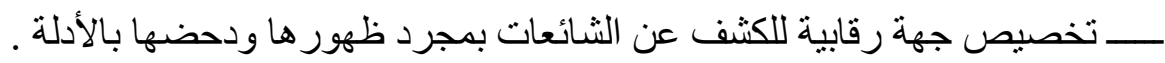
ـــــــيق مبدا الثفافية وسر عة مو اجهة الثنائعات بالبيانات و الحقائق الد قيقة . ثالثاً : مقترحات بحثية للاراسات المستقبلية :

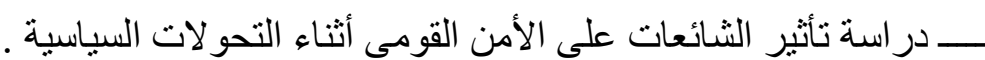

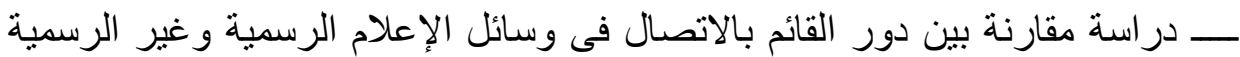

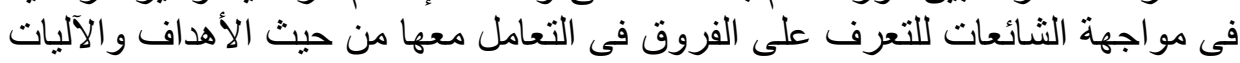
وطرق المواجهة .

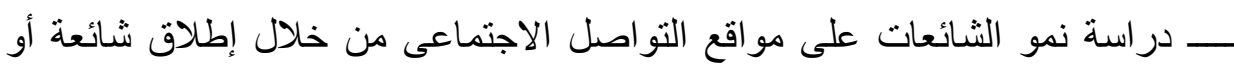

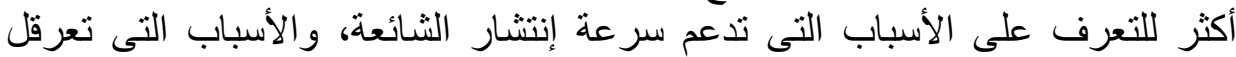

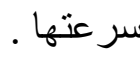
ــــ إجر اء در اسة لمعرفة رأى النخبة عن تأثير وسائل الإعلام فى انتشار الشائعات . 


\section{قائمة المراجع \\ اولاً : المراجع العربية

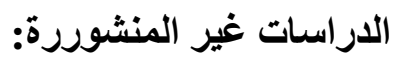

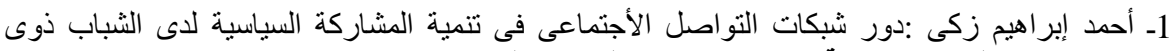
الإحتياجات الخاصة، رسالة ماجستير( جامعة القاهرة :كلية الإعلام، لثية 2017 ).

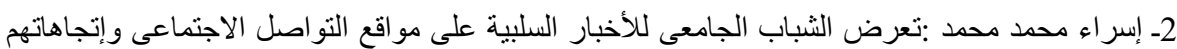

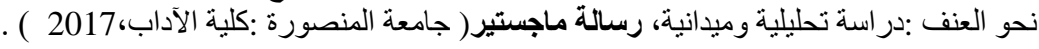

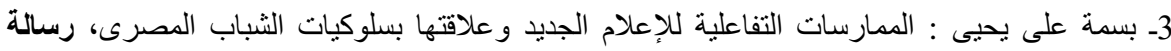

ماجستير( جامعة المنصورة :كلية الآداب، 2017 ) .

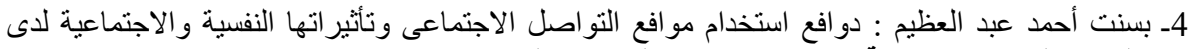

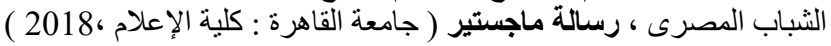

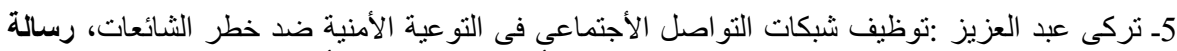

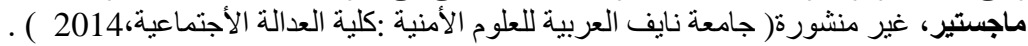

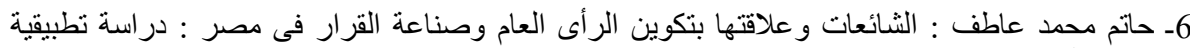

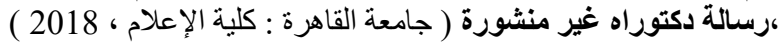

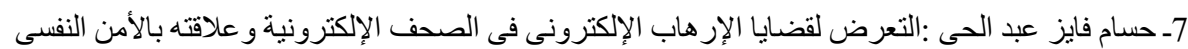

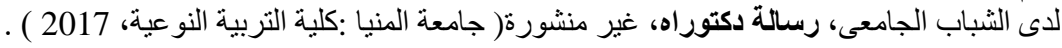

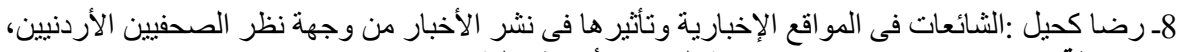

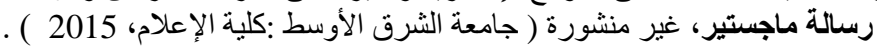

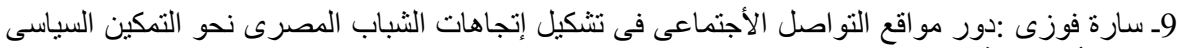

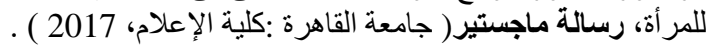

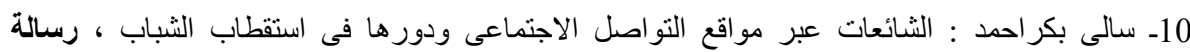

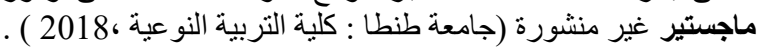

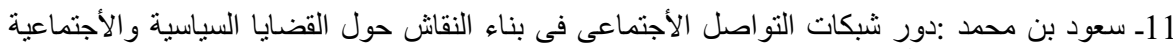

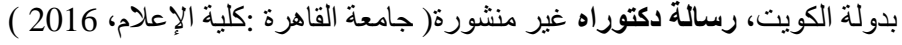

12- سعاد بن الحديدى :علاقة مستوى النرجسية بالإدمان على شبكات التو اصل الأجتماعى، رسالة دكتوراه

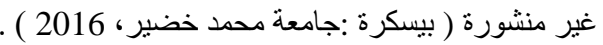

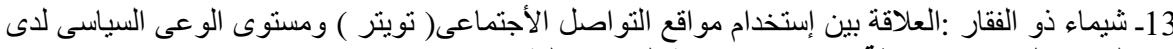

الثباب المصرى، رسالة ماجستير،(جامعة القاهرة :كلية الإعلام، التهاعل 2017 ) .

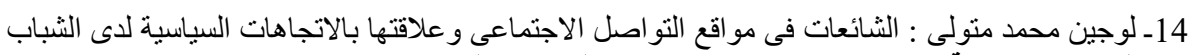

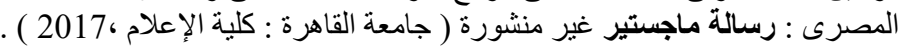

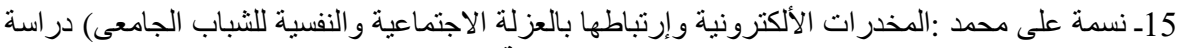

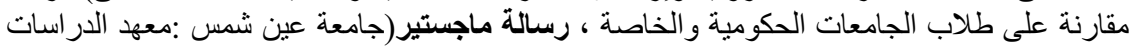

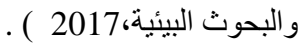

16- نورهان مصطفى : دور مواقع التواصل الاجتماعى فى نثر الثائعات وتأثير ها على الأمن القومى الثى

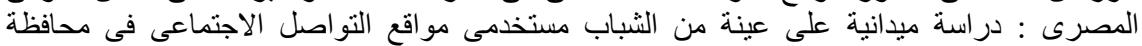

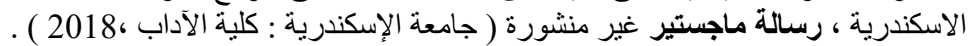


17- نور مصطفى النشار : تعرض المراهقين لثائعات مواقع التواصل الاجتماعى وعلاقتها باتجاهاتهم ) ماتهر

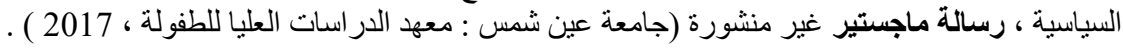

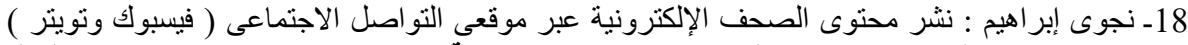

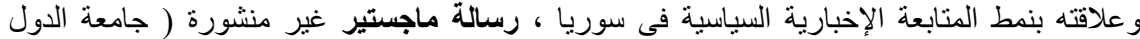

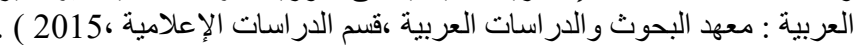

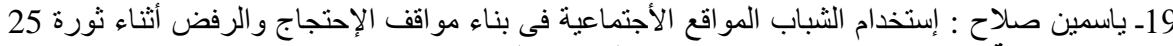

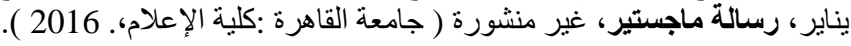

الاراسات المنثورة فى الدوريات العلمية:

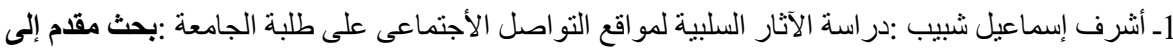

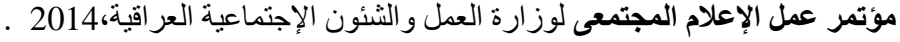

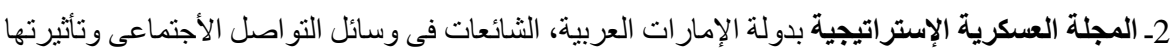

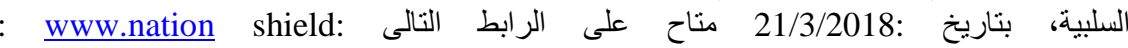
. ael/homo/details/2017.

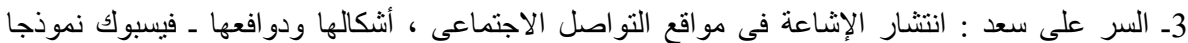

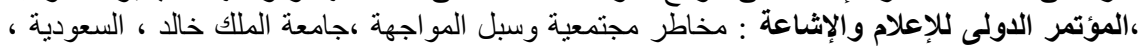

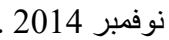

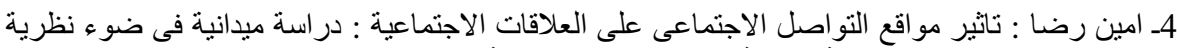

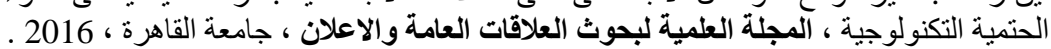

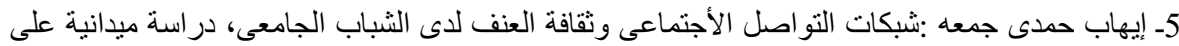

عينة من طلاب جامعة الأسكندرية، المؤتمر العلمى الدولى الثانى والعشرون، القاهرة :كلية الإعلام، 3 4مايو 2016 م.

6ـ بدر الأنصارى : القلق لاى الثباب فى الوطن العربى ، مجلة رابطة الأخصائيين النفسيين ، مج 14 ،ع 3 ، . 2004

7ـ دعاء حامد حلمى :إستخدام الثباب الجامعى لمواقع التواصل الاجتماعى ودور ها فى دعم أعمال العنف

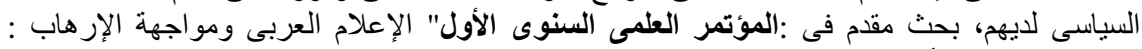

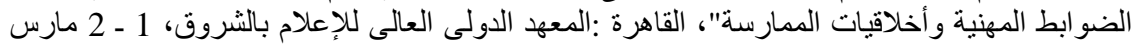
.2016

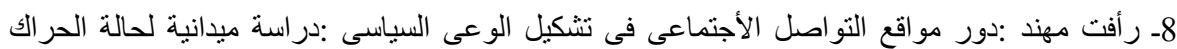

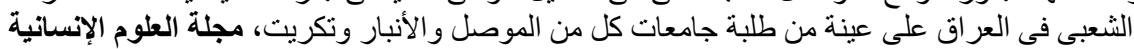
و الاجتماعية، الأردن،2016.

9ـ حمدان خضر سالم : طر ائق مواجهة الثائعات فى مواقع التواصل الاجتماعى ، مجلة الباحث الإعلامى ،ع 2018، 41

10- سعد بن سعود : الأخبار السلبية على شبكات التواصل الاجتماعى وعلاقتها بمستوى القلق لاى الثباب

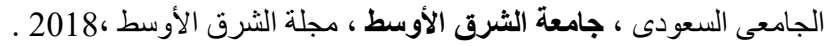

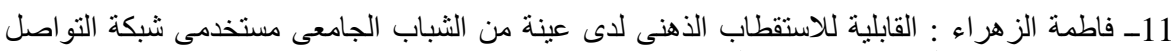

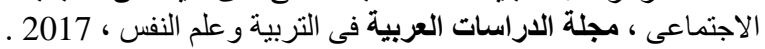

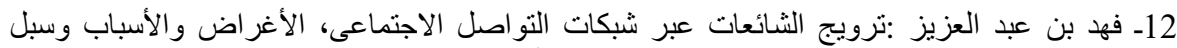

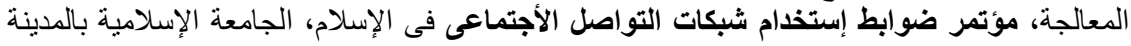




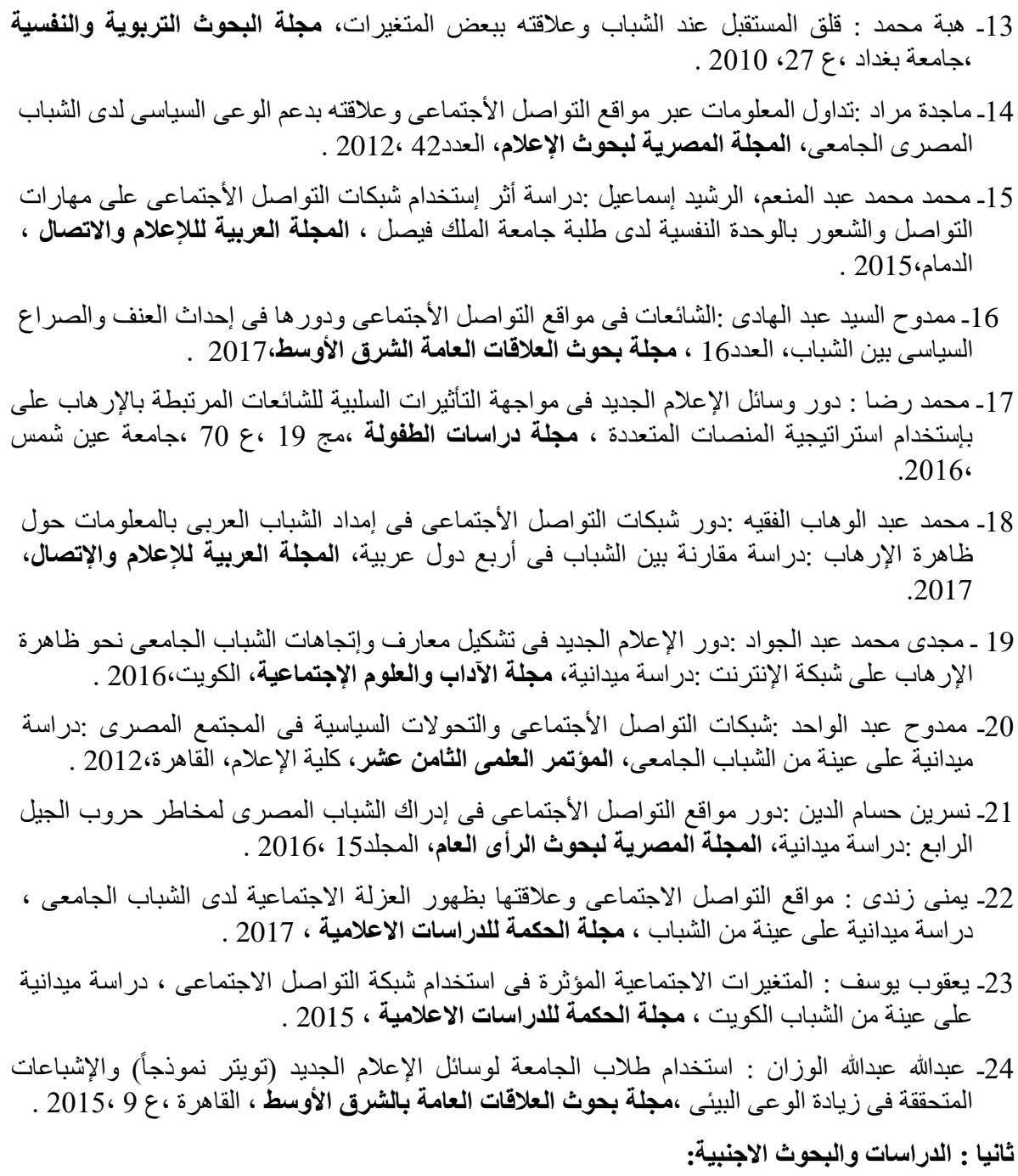

1. Amin Mansour: The Role of Social Network in Enhancing The Ethical values inside the plestinain society, A field study on media students at Gaza University, IUG Journal of Humaniteis Research, Islamic University of Gaza, 2017.

2. Asma Hely: Psychological Disorders Associated with the use of social media sites for University Student, Islamic University, Journal of Education \& Psychological Studies, Vol. 25, 2017.

3. Asma A. Alhamd: The influence of social media on Saudi Graduate Students: An explanatory case study of six Saudi graduate studying in American University, Ph.D. Kansas State University, 2017.

4. Arkiatz Zubiaga : Detecting and resolution of Rumors in social media : Asurvey ACM computer surveys ,vol.51 ,No.2 2019. 
5. Banks, James: Regulating hate speech on line International Review of Law, Computer and Technology, Vol. 24, No. 3, 2013.

6. Benjamin Doerr : Why Rumors spread fast in social network, paper presented in university of sarriands ,Germany ,2017 .

7. Fredric Romanus: On line Social Net Works and Terrorism in Developing countries, International Journal of Computer Science \& Network solution, Vol. No. 4, 2013.

8. Francis Blooth : Rumors and social media ,Journal of American statistical Association, 2016.

9. Gabriel Weiman: New Terriorm and new media research, research series Washington Commons Labe of The Woodrdu Wilson International Center for Scholars, Vol. 2, 2014.

10. Garett, Liusean: The relationship between social media use and sleep quality among ungraduated students, Journals Information, Communication \& Society, 2017.

11. Gehad M. Ashraf, Mahdi, A. Muso: An Examination of Social Networking sites usage among Muslims Students in Islamic perepectives, International Journal of Engineering and advanced technology. Vol. 1, 2012.

12. George C. Formukong: The import of social media and terrorism, M.A Thesis, Utica College, 2017

13. Gene V Glass: Primary secondary, and Meta-Analysis of research, Educational Researcher, November, 1976, Vol 5. Pp 3-8.

14. Ghualm Shaber \& Yosef Mahmoud: The impact of social media on youth. A case study on behawalpur city, Asian Journal of Social Science \& Humanities, Vol. 3, No. 4, 2014.

15. Heng Chen: The power of whipers: Theory of Rumor communication, Hong Kong University of Science and Technology, 2011.

16. Kevin Koidle \& Tara Mattews : Measuring impact of Rumors Message in social media ,Paper presented in university of Dublin ,Ireland ,2018.

17. Killy .A Rodamer : Negative plotical campaign and voter response : The implications of images attack ADS on young, first time voters ,M.A thesis, North Kentucky university ,2018.

18. Jamie Hardee: The United States and The European Response to international terrorism, M.A. Thesis, Untica University, 2016.

19. Jorgad Petroski: Terrorism group Recruitment Tactics using social media on Internet, M.A. Thesis, Utica College, 2017.

20. Jeffery Channa : social media in the arab world leading up to the uprisings of 2011 aerport to center for international communication association ,2011.

21. K. Jill Kiecolet and Laura E. Nathan: Secondary Analysis of survery Data, series: Quantitative Application in the social science, sage university paper, 1982, p. 10.

22. Kendra M. Fuentes: Cyber Terrorism: The use of social net working to recruit westerns in informational guide for law enforcement. M.A., Thesis Utica University, 2017. 
23. Khuaran N.: The impact of social net working sites on youth, mass communication Journalism, Vol. 5, No. 12, 2015.

24. Lucia Vesnic: Political participation and Web 2, o in Europe: A case study of face book, In: Public Relation Review, Vol. 38, No. 3, 2012.

25. Jae Seon : What influences rumors acceptance and support for participation in sociopolitical issue ? Analysiszing the role of patterns and levels of communication ,International journal of communication ,vol.12,2018 .

26. Meredith Conroy \& Others: Facebook and political engagement: A study of online political group membership and office political engagement, in: Computers in Human Behaviour, Vol. 28, No. 5, 2013.

27. Mahmood, Shanayara \& Farooq, Umer: Faceebook addition: A study of bigfive factors and academic performance among student, Global of Management and Business Research, 2016.

28. -Mangala vivakana ,M.neelamala : platforms for educational purpose among faculty of Higher education special effnce to tamil nadu, Higher Education for future ,vol,5,No,1,2018.

29. Maren H. Bjoergum: The difference inframing traditional media and twitter after the Boston Marathon Bombing, M.A., Hawai University, 2014.

30. Michal J.scialdone : Under strading the use and Impact of social media feature on education exprience of higher education students inblended and distance learing enironment ,PHD .,syracuse university new york 2014.

31. Nahed Eltantawy, Julie Wies: Social media in The Egyptian Revolution Reconsidering Resource Mobilization Theory, International Journal of Communication, No. 5, 2011.

32. Newman Nic \& Levy A.L.: Reuters institute news report 2014 tracking the future of news, available online: http.//reuter institute news. Politics. Ox.ac.uk/sites/default/ files/ pdf.

33. N. Ramesh Masthi \& Shreyas: International Journal of Health \& Allied Science, Vol. 4, No. 1, 2015.

34. -Paravthy, Suchithra : Impact of usasge of social net working sites on youth, International Journal of computer Application ,vol 129 ,No,3,2015.

35. Parvathy, J. \& Suchithra, R.: Impact of usage of Social Net Working sites on youth. International Journal of Computer Application, Vol. 129, No. 3, 2016.

36. Research: An Introduction, Canda, Wads Worth, 2011, p. 19.

37. Rita N Joroge: Impact of social media, the youth on behavior change: A casee study of university students in Nairobi Kenya, M.A. Thesis, 2014.

38. Roggen D. Wimmer and Joseph R. Dominick, Mass media

39. Rothenbergerrliane: Terrorist Groups: Using Intenterent and Social media for Disseminang Ideas, Roman Journal of Communication and Public Relation, Vol. 14, No. 3, 2012.

40. Sadia Malik \& Maheen Khan: Impact of facebook addition on narcissistic behavior and self esteen, among students, Journal of Pakistan Medical Association, Vol. 65, No. 3, 2015.

41. Santa Barba: Media treatment of Fukushima, M.A. Thesis, University of California, 2014. 
42. Scharz, Elizabeth : Political mobilization of under graduates through on line social net work ,Behavior and social net working,2013 .

43. Shary I.N. Dr: Russia and countering violent extremism in internet and social media, Journal of Strategic Security, Vol. 6, No 4, 2016.

44. Sunitha Kuppuswamag: A perception study on community response to media technologies in south india, Science Technology Society, Vol. 19, No. 3, 2015.

45. Taeyoung Lee : Perceved influence of fake news and its consequences ,M.A Thesis ,Indiana university ,2018 .

46. Villi, Matikko: Mobile UDC online media content distribution among finish mobile internet users, mobile media of communication, available online: http//mmc.sagepub, com/content/early/2016/ pdf,html.

47. William Rebert Ais: The role of online social media in countring vident extremism in the East Africa, GSDRC Help Desk Research Report 2017, Available: file: ///c:/users/dell/2017/ DWanloads/File. Pdf.

48. Weiwu Zhang :Therevolution will be net work the flunence of social net working sites and political attitudes ,socialscience and computer review ,2016.

49. Yi Mou: Communicationating Food Safety Via the Social media. The Role of knowledge and emotions on risk perception and prevention, Science Communication, Vol. 36, No. 5, 2015.

50. -Zywica Jolen : The face bookers : Investingating enhangment and social compensation ,Journal of computer medited communication ,2016. 